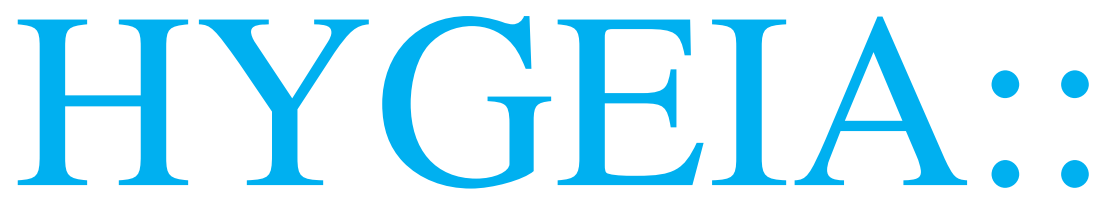

\title{
Journal for drugs and medicines
}

Vol.3 (2), Sept. 2011-March2012.

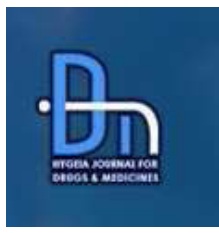

ISSN 22293590 (ONLINE), 0975 6221(PRINT)

www.hygeiajournal.com 
Vol.3 (2), Sept. 2011-March2012.

\section{Hygeia :: journal for drugs and medicines}

'Hygeia: journal for drugs and medicines' is a half yearly international open access journal specifically intended to publish papers concerning Pharmaceutical Sciences like Medicinal Chemistry, Formulation technologies, Pharmacognosy, Medicinal Natural products, Pharmacology, Clinical pharmacy, Bio-technology, BioPharmaceutics, Pharmacy practice and other related fields.Original and informative scientific research and review articles are invited for publication in the journal. Manuscript should be typewritten, strictly following the "Instructions to authors" which is being published in' Hygeia'. Contributions must be original and submitted as full papers, short communications, review articles, scientific correspondence or as research news. Authors are requested to submit the manuscript through electronic mail to the address hygeiajournal@gmail.com

Hygeia was the Greek goddess of health and she was worshiped in connection with Aesculapius, her father, the god of medicine and health. She is said to be again, the grand daughter of the God, Apollo. She is also the sister of Panakeia or Panacea (means all-cures) Akeso (Goddess of Healing), and Iaso (which means Remedies). Hygeia is usually depicted as a young woman, who holds a sacred snake (symbolizes resurrection), which is often combined with the rod of Asclepius to form the cadacus, or symbol of medicine. Often this snake is portrayed as drinking from a cup (symbolizing medicine), which has become known as the pharmacist's bowl.

Originally, she was the guardian of physical health and later became the goddess of mental health, as well. Eventually, she became a protectress against various kinds of danger, an attribute which she shared with Aesculapius. It is from Hygeia, the word hygiene originates. Hygiene is the science of preserving health. The subject of hygiene includes all of the agencies affecting the physical and mental well being of people. In its public aspects, it is concerned with soil; climate; character; materials and arrangement of dwellings; heating and ventilation; removal of wastes; medical knowledge on the incidence and prevention of disease; and the disposal of the dead.

\section{www.hygeiajournal.com}

Editorial I Design of Drugs \& Medicines I Health \& Nutrition I Formulation Technologies

Pharmaceutical Updates \& Reviews I Downloads

(c) 2011 Hygeia journal for drugs and medicines, all rights reserved. 22293590,0975622 


\section{Hygeia.J.D.Med. vol. 3(2) Oct.2011-March 2012}

Synthesis and Analgesic activity studies of Simple new Aspirin Enkephalin analogues

J. Balamani* \& M. Sekar

http://www.hygeiajournal.com/Downloads/13452570821.m.sekar.pdf

Anthelmintic activity of Neolamarckia cadamba barks

S. Mondal*, H. Ramana and P. Suresh.

http://www.hygeiajournal.com/Downloads/13220076622.sumanta\%20mondal.pdf

Stable expression of modified Gene encoding functional Human coagulation Factor viii Ebrahimi Ammar, Khaniani S Mahmoud, Mansoori Sima

http://www.hygeiajournal.com/Downloads/11540752823.Ebrahimi\%20iran,.pdf

Evaluation of the Antibacterial activity of Cocculus hirsutus

Abiramasundari.P, Priya .V, Jeyanthi.G.P, and Gayathri Devi. S*

http://www.hygeiajournal.com/Downloads/8818372494.gayathri.pdf

Anti hyperlipidemic activity of Spirulina platensis in Triton x-100 induced hyperlipidemic rats.

S.S.Sudha*, R.Karthic, Naveen, J.Rengaramanujam

http://www.hygeiajournal.com/Downloads/2337269785.SUDHA.pdf

Synthesis and Ulcer reducing activity studies of some Peptide derivatives of Aspirin

M.Sekar* and J. Balamani

http://www.hygeiajournal.com/Downloads/2104387826.aspirin.pdf

Design, Synthesis and Biological evaluation of Pyrazole analogues of Natural Piperine

Anny Mathew*, Mary Sheeja T.L, Arun Kumar.T, K.Radha

http://www.hygeiajournal.com/Downloads/16125768447.anny.pdf

Simultaneous Multicomponent Spectrophotometric analysis of Ampicillin and Probenecid in Pharmaceutical formulation by Derivative spectroscopy

Thomas Kurian* and Jose Kurien

http://www.hygeiajournal.com/Downloads/16093414608.jose\%20kurien.pdf

Editorial I Design of Drugs \& Medicines I Health \& Nutrition I Formulation Technologies Pharmaceutical Updates \& Reviews I Downloads 
(n)

DD

Editorial Board

Editor - in - Chief and Managing Editor

Dr.Madhu.C.Divakar,B.Sc, M.Pharm, PhD, PGDHRM

Director \& Professor, Crescent College of Pharmaceutical sciences, Kannur,Kerala,India.

madhu.divakar@gmail.com

Editorial Board (Technical)

Mr.Prasanth.R. M.Pharm, Mr.Subash Philip. M.Pharm,

(Crescent College of Pharmaceutical Sciences, Kannur, India.)

Mr.Siyad.AR, M.Pharm. (Mangere Community Pharmacy, 12 Waddon Place, Mangere, Auckland, New Zealand)

Mr.Yuvaraj.S. M.Pharm (Christian Medical College, Velllore, Tamilnadu, India.)

Editorial Board (Reviews \& Information)

Mr.VinodK.R. M.Pharm, FAGE, PGDMM, Nalanda College of Pharmacy, Nalgonda, Andhra Pradesh, India

Mrs.Sandhya. S, M.Pharm, FAGE, Nalanda College ofPharmacy, Nalgonda-508001, Andhra Pradesh, India.

Mrs.LakshmiDevi.S, M.Pharm, SriRamakrishna College of Pharmacy, SRIPMS, Coimbatore, TamilNadu, India.

Dr. C Srinivas Reddy M.Pharm, PhD, Principal \& Professor, VaagdeviCollege of Pharmacy, Ramnagar, Warangal, AP, India.

Board of Advisors

Prof.Dr.Hilbert Wagner, MS (Pharm) PhD.

Professor, University of Munich, Institute of Pharmacy, Pharmaceutical Biology, Butenandtstrasse5, D-81377, Munich, Germany.

Dr.N.Radhakrishna Pillai M.VSc., PhD.

Asst.Director (Retd), Regional Research Institute, Thiruvananthapuram, Kerala ,India .

Prof.Dr.Elizabeth M Williamson, MS(Pharm), PhD.

Professor of Pharmacy and Director of Practice ,The School of Pharmacy, University of Reading, Whiteknights, Reading RG6 6AJ, Berkshire, U.K.

Dr. D.Suresh Kumar, M.Sc, PhD.

Sr. Scientist, Sami Laboratories Ltd, Bangalore, India 560058.

Dr. Arun Shirwaikar, M.Pharm, PhD.

Dean, Professor of Pharmaceutics, Gulf Pharmacy College, Gulf Medical University, Ajman, U.A.E

Dr. Annie Shirwaikar, M.Pharm, PhD.

Professor, Gulf Pharmacy College, Gulf Medical University.Ajman,UAE.

Dr.T.Emilia Abraham, MSc,PhD.

Senior scientist-F ,Chemical Sciences and Technology Division, National Institute for Interdisciplinary Science and Technology ,

Council of Scientific \& Industrial Research (CSIR), Thiruvananthapuram, India, 695019.

Dr. Unnikrishnan M.K, M.Pharm, PhD.

Professor, Manipal College of Pharmaceutical Sciences, Manipal University, Manipal, Karnataka, India.

Dr. S.P. Dhanabal, M.Pharm, PhD.

Professor \& Head, Dept. of Phytopharmacy and Phytomedicine, JSS College of Pharmacy, Rocklands, Ooty,Tamilnadu, India.

Dr. Senthil Kumar Pazhanisamy, B.Pharm, M.Tech (Biotech.), PhD.

Research Asst.Scientist, Pathology \& Lab Medicine, Medical University of South Carolina, Charleston, USA.

Dr.N.Udupa, M.Pharm, PhD.

Dean and Professor, Manipal College of Pharmaceutical sciences, MAHE Manipal,Karnataka, India.

Dr.C.Veeresham, M.Pharm, PhD.

Professor of Pharmacy, University College of PharmaceuticalSciences Kakatiya University, Warangal AndhraPradesh- 506009 ,India. 
Dr.P.Vijayan. M.Sc, PhD.

Professor of Biotechnology, JSS College of Pharmacy, Rocklands, Ootacamund, Tamilnadu, India - 643001

Mr.K.C. Sivakumar MSc. MBA.

Information Officer, Bioinformatics Facility,RajiveGandhi Center for Biotechnology, Thiruvananthapuram, Kerala, India 695014.

Dr. B. C. Behera. MSc,M.Phil.,PhD.

Scientist-D, Agharkar Research Institute, Autonomous Institute of Department of Science and Technology, Govt.of India, G.G.

Agarkar Road, Pune-411004, INDIA.

Dr.L.Panayappan.M.Pharm,PhD.

Director,Pasumai Pharmacy,India (P) Ltd. pasumaipharmacy@yahoo.co.in Professor \& Head, Department of Pharmacy Practice, JKK Nataraja college of Pharmacy, Kumarapalayam, Erode, Tamilnadu,India.

Dr. Narayanacharyulu R, M.Pharm, PhD .

Professor of Pharmaceutics, NGSMIPS, Mangalore, India.

Dr.K.S.Prasanna, M.VSc, Ph.D.

Diplomate, Indian College of Veterinary Pathologists (ICVP) Assistant Professor, Dept.of Vet. Pathology, College of Veterinary and Animal Sciences, Pookot, Wayanad, Kerala, India.

Dr.Nirmal Robinson, M.Pharm, Ph.D.

Post Doctoral Fellow, NRC-Institute forBiological Sciences M-54, -1200 Montreal Road, Ottawa, ON-K1A 0R6, Canada.

Dr. K. Gowthamarajan. M.Pharm., PhD.

Professor \& Head, Dept. of Pharmaceutics, JSS College of Pharmacy, Rocklands, Ootacamund, Tamilnadu, India - 643001

Dr.Sriram S.M.Pharm., PhD.

Professor \& Head ,Department of Pharmacy Practice, Sri Ramakrishna college of Pharmacy, SRIPMS,

Coimbatore,Tamilnadu, India - 641044.

Dr.B.Narasimhan , M.Pharm., PhD.

Associate Professor, Dept. of Pharmaceutical Sciences, M.D. University, Rohthak, Haryana., India.

Dr.Shirley Samson Varughese M.Pharm, PhD

Sr.Pharmacologist, Pharmaceutical Affairs \& Drug Control

Ministry of Health, Sultanate of Oman

Dr.S.Radhakrishnan, PhD (Psy)

Director, SKITRAC (Skills Training Centre)

8/1M Mansion building ,Race Course, Coimbatore -18, India.

email.drmindsr@yahoo.co.in

Dr.Konstantinos M. Kasiotis, PhD

Research Assistant

Benaki Phytopathological Institute, Department of Pesticides Control and Phytopharmacy,

Laboratory of Pesticides Toxicology, 8 Stefanou Delta Str.,

Kifissia, Athens, Greece 14561

\section{Place of publication}

12/3,NehruNagar,Ganapathy,Coimbatore, Tamilnadu,India.641006

+914222539477, +919895017413

hygeiajournal@gmail.com

Hygeia.J.D.Med.2229 3590, 09756221

Editorial I Design of Drugs \& Medicines I Health \& Nutrition I Formulation Technologies

Pharmaceutical Updates \& Reviews I Downloads

(C) 2012 Hygeia journal for drugs and medicines, all rights reserved. 22293590,0975622 


\section{Instructions to Authors}

'Hygeia journal for drugs and medicines' is specifically intended to publish papers concerning Medicinal Chemistry, Formulation technologies, Medicinal Natural products, Pharmacology, Clinical Pharmacy,PharmaceuticalBiotechnology,Pharmacoeconomics,Pharmaco bio informatics, BioPharmaceutics,Pharmacokinetics,Pharmacovigilance, and other related fields. Contributions must be original and submitted as full papers, short communications, review articles, scientific correspondence or as research news. Manuscript in English should be submitted to the Editor by E-mail. In any case the decision to accept the contribution rests with the editors to make alternations in the text of contributions if they are not confirmed with accepted scientific standards or if they are too repetitive. All contributions must include a brief and clear title, initials of fore name, surname and address of each author.

Full papers must include: -

\section{Abstract}

A summary of not more than 150 words should be clear and factual in content. Abstract must present the reason of study, the main findings and principal conclusion. Follow the structured abstract pattern and include Plan, Prologue, Methodology, Outcome and key words of the research work.

\section{Introduction}

The introduction should supply adequate background information to allow the reader to understand and evaluate the results of the present study, and the purpose of study should be clearly stated.

\section{Materials and methods (Experimental)}

The section on materials and methods should include brief details on the methodology adopted sufficient to repeat the experiment. Methods for which adequate references can be cited are not to be described. Units of measure should be metric or preferably SI methods.

\section{Results and Discussion}

This section include only the results of the experiments, important findings, should be stated in a relevant sequence. Illustrate the results with figures or tables in a concise manner where necessary. Results must be precise and comprehensive and should not suffer from ambiguities.

\section{Conclusion}

This part should provide an interpretation of the results in relation to previously published work and to the experimental system followed to the present study. Do not repeat data already stated in results in details. All illustrations must be numbered using Roman numerals in their order of citation in the text.

Illustration may be accepted if they enhance a paper's content scientifically. Every table must be on a single separate sheet presented neatly depicted on good quality tracing paper.

\section{Acknowledgment}

Acknowledgment of financial assistance and of personnel assistance is given in separate paragraphs.

\section{References}

The references section must include all relevant sources and all listed references must be sited in the text.

Follow the styles shown in the examples below: (for Journals and published books)

1. Author $\mathrm{AB}$, Author $\mathrm{CD}$, article title, journal title, vol, issue, year, page no.

2. Author $\mathrm{AB}$, title of the book, Publisher, Place of publication, edn, year, page no.

3. Web sites: official Govt. web sites (for research) can be included. Author AB, Title, Publisher, date of publication , date of Update/revision, Available from http://www.hygeiajournal.com

\section{For short communications}

The divisions of the manuscript into separate section are unnecessary and only a discussion and an experimental section must be reported.

\section{Review Articles}

(Not exceeding 5,000 words) must Project new concepts in a presentable manner. Scientific correspondence contains technical comments from the published articles.

\section{Research News and views}

Information about various new and novel, technical and scientific advances in Pharmaceutical field or related scientific areas. 


\section{Abbreviations of journal names}

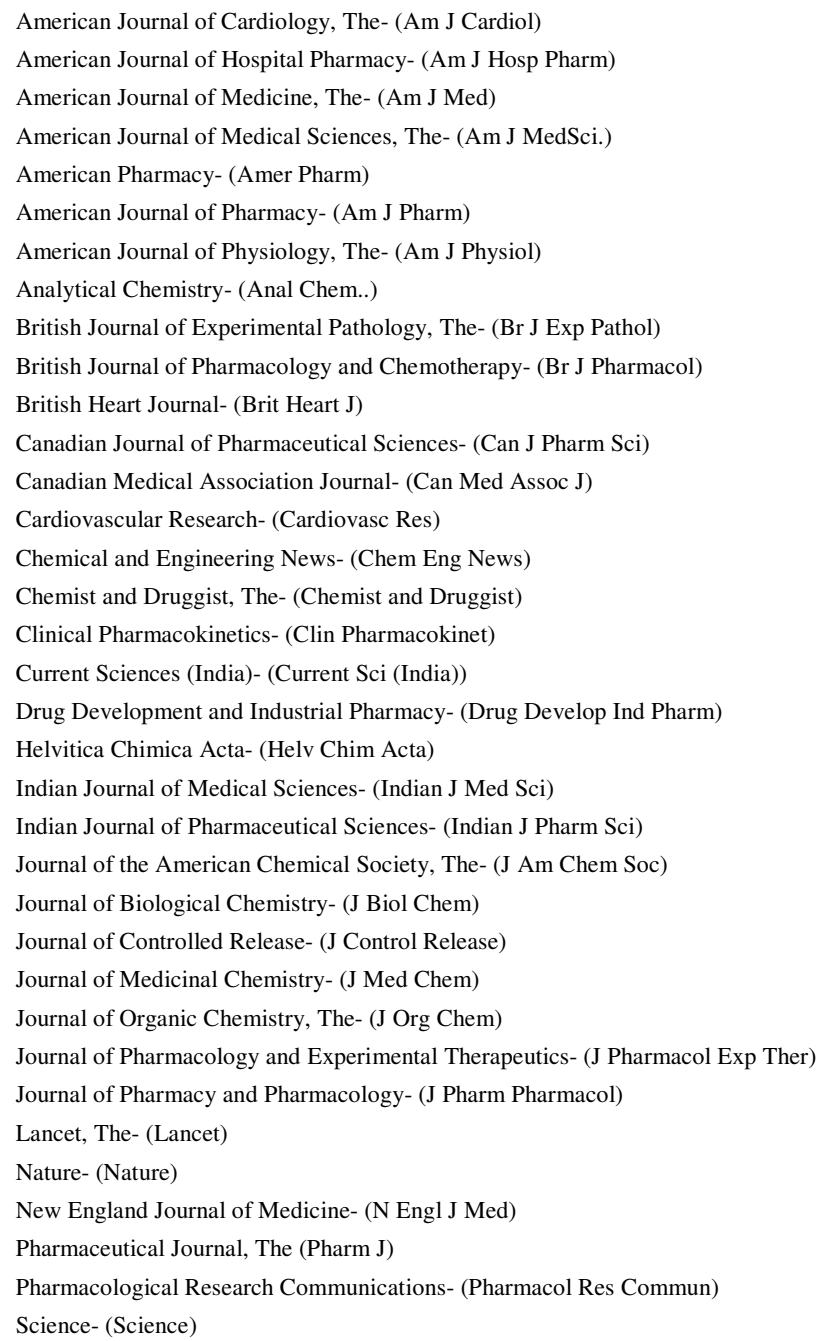

Authors are requested to submit the manuscript using online submission form. or E-mail us at hygeiajournal@gmail.com

Editorial I Design of Drugs \& Medicines I Health \& Nutrition I Formulation Technologies Pharmaceutical Updates \& Reviews I Downloads

(c) 2012 Hygeia journal for drugs and medicines, all rights reserved. 22293590,0975622 


\section{Pharmaceutical horrors of the environment: An emerging concern}

\section{Dr.MK Unnikrishnan, M.Pharm, PhD.}

Professor, Manipal College of Pharmaceutical Sciences,

Manipal University, Manipal, Madhava Nagar

Karnataka, India- 576104

Fax: 00918202571998

mkunnikrishnan@gmail.com

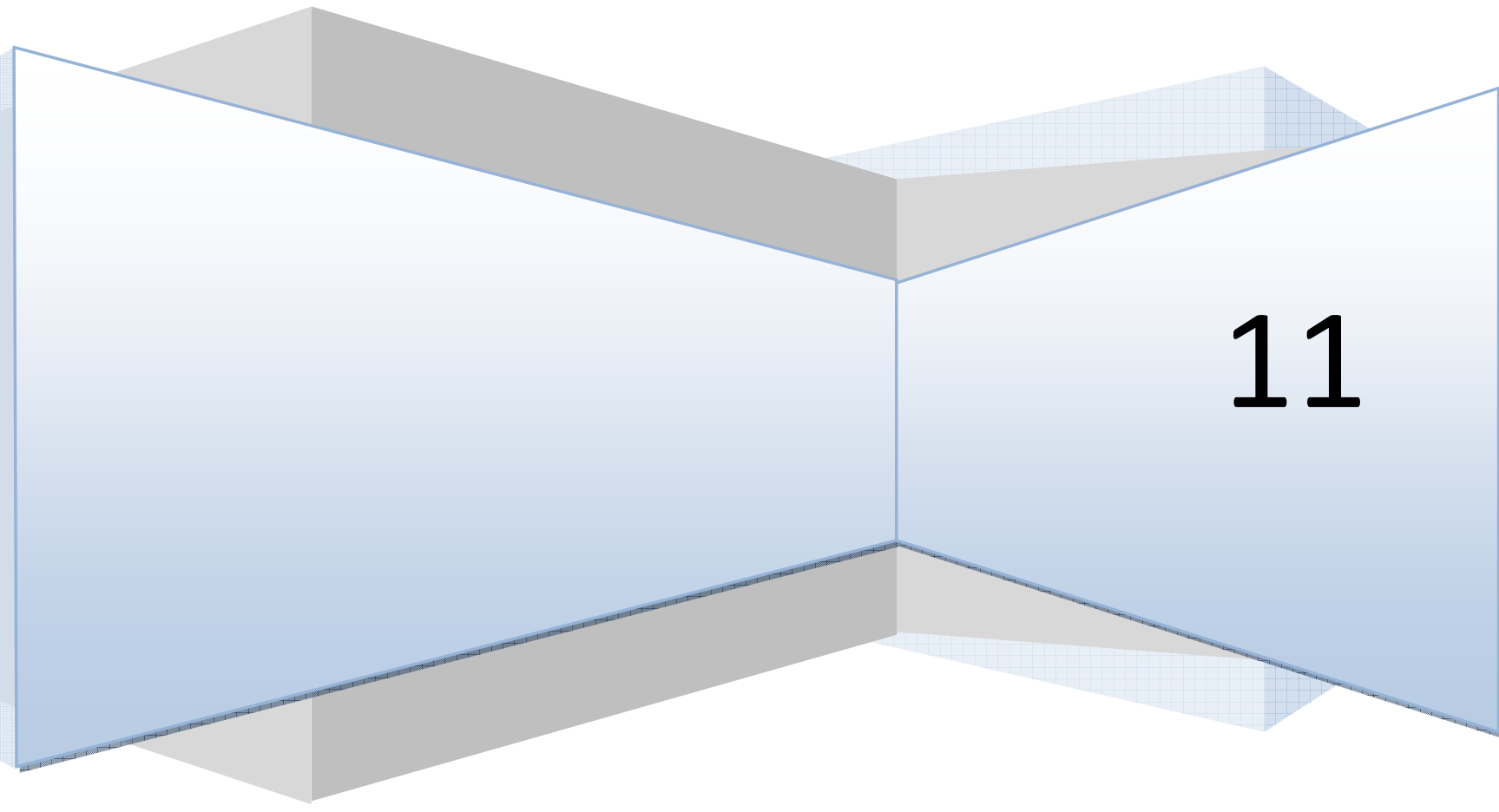




\section{"Don't join a queue if you don't know what is at the end of it" - Challis}

There was a time we could enjoy a train ride in rural India, with its pristine countryside, mostly verdant and fresh with unpolluted air ...

But not any more...!!

Nothing ruins the landscape as permanently as the indestructible plastic garbage. India, despite its recent rise to a global power, has been notoriously callous towards the upkeep of the environment. Even educated people have no qualms about throwing an empty bottle of mineral water out of the train window.

Plastic waste is only the most visible of pollutants; we must not forget that there is much more to environmental pollution than plastic bags and P E T bottles. The hazard is more than what meets the eye, much more than what a person of average education can even guess. Not even the most well informed citizens are aware of the scale and magnitude of the horrors of environmental pollution. From drinking water to industrial emissions, everything we see around us has been devastated, paradoxically perhaps, by the hands of 'industrial development' and the 'rising standards of living'.

Indian pharmaceutical industry has been among the most successful enterprises that emerged in Independent India. It is 'a rags to riches' story in which India has become a global leader, producing and exporting active pharmaceutical ingredients (APIs) and formulations that meet approximately $40 \%$ of the world's API requirements and $90 \%$ of the domestic needs.

The current growth rate in pharmaceuticals is among the highest in the industrial sector. The burgeoning interest in pharmaceutical education appears to be the result of this phenomenal success story.

That pharmaceuticals pose a threat to the environment was not fully appreciated until early 1990s, when the near extinction of vultures (up to 95\%) in the Indian subcontinent was traced to diclofenac-induced kidney failure in vultures that fed on abandoned carcasses of cattle dosed with diclofenac. A flurry of research that followed not only confirmed that drugs can be environmental hazards but also proved that the diclofenac episode is just the tip of the iceberg.

Every pill eventually ends up in the environment. Chemical properties that render medicinal value also make drugs the most persistent, lipophilic and non-biodegradable residues in the environment. Drugs also tend to accumulate in terrestrial and aquatic organisms. The presence of carbamazepine (up to $18 \mathrm{mcg} / \mathrm{L}$ ) in Kaveri is an indication of how these stubborn sewage residues end up in rivers. $95 \%$ of antibiotics are excreted unaltered. Studies in the West have shown that up to $54 \%$ of people throw medicines into trash or flush them in the toilet. 
The general water treatment plants are ill-equipped to handle pharmaceuticals. Traces of prescription drugs have been detected in drinking water supplied to millions of American homes. Ethinyl estradiol in effluents has resulted in feminization of fish downstream of sewage plants. Propranolol, Diclofenac, Ibuprofen and Fluoxetine have been detected in environmentally relevant levels. Thus, "drugs pollute not only the bodies of patients who take them but also the environment where residues accumulate". The Central Pollution Control Board has ranked pharmaceutical industry as one among the seventeen highly polluting industries of the nation.

Drugs are not only used to heal the sick, but also to run profitable commercial enterprises. Antibiotics are used against orchard pathogens and as feed supplements in poultry, shrimp and pig farms. Pig house dust accumulating from feed, bedding and faeces was found to contain five antibiotics in a combined concentration of $12.5 \mathrm{mg} / \mathrm{kg}$. The emergence of antibiotic-resistant bacteria has also been attributed to selection pressure created by multiple antibiotics in effluents. Thus, what might be interpreted as a local problem could soon become a recalcitrant global burden in the treatment of infectious diseases.

If the extinction of vultures was an eye opener to the potential hazards of drugs in Indian environment, the results of a relatively recent study on the effluents at Patancheru by Swedish scientists opened the Pandora's Box of pharmaceutical pollution in India.

\section{Mind-boggling Pollution!}

Patancheru Enviro Tech Ltd (PETL) near Hyderabad was built for treating the abundant industrial waste generated by 90 odd bulk drug manufacturers. The clarified effluent released from the plant has been shown to eventually merge with Godavari. Wastewater downstream showed 150 times the highest levels of pharmaceuticals detected in the United States. Out of the 59 APIs tested, 21 were detected at levels greater than $1 \mathrm{mcg} / \mathrm{L}$.

More than 11 drugs were detected at the highest level ever in the planet. Ciprofloxacin was detected at $31000 \mathrm{mcg} / \mathrm{L}$ which is much greater than the maximum therapeutic plasma level. Each day's discharge from PETL had up to $45 \mathrm{~kg}$ of ciprofloxacin, which is enough to meet the needs of the Swedish market for five days. The combined quantity of APIs in the effluent was estimated to be worth $€ 100,000$ in Sweden!

Swedish team went further. They subjected the Patancheru effluent to a variety of tests in which they observed up to $40 \%$ growth reduction in tadpoles, even at the lowest concentrations. Even when diluted 500 times, this notorious effluent increased global gene expression and cytochrome P450-1A activity in fish. Scientists have warned that antibiotics in the effluent could increase selection pressure and thus promote the transfer of resistance-genes from harmless environmental microbes into deadly pathogens, leading to the emergence of deadly drug-resistant microorganisms. 
Even the farmers have not been spared: paddy output in the vicinity of Patancheru dropped from 40 bags per acre to 10 bags per acre. Probably inspired by the research carried out by the Swedish scientist in 2007, the Government of India, Ministry of Chemicals \& Petrochemicals set up an Environment Cell in November, 2008. The timing of the event is unmistakably linked to the fact that the wake-up call must come from data generated abroad!

The recent FIP meeting at Hyderabad in September 2011 engaged a special session on the environmental hazards of pharmaceutical manufacture. A team of visitors, mostly from Scandinavian countries, expressed regret at the situation emerging in the third world. Sweden's Medical Products Agency Report to Swedish Government has recommended reduction in outsourcing manufacture of APIs to countries that neglect environmental pollution in addition to effecting suitable GMP revisions to control emissions.

The new EU regulations would have to specify and prioritize proven hazards. Would it mark the beginning of the end of pharmaceutical pollution in India? Or would it be the end of Indian advantage in the competitive pricing of APIs for the global market?

Let us hope for the best!

\section{References:}

CHOI, C. Q. , Pollution in Solution, Drug-Resistance DNA as the Latest Freshwater Threat. Scientific American, 2007, 296, 22-23

CARLSSON, G., ORN, S. \& LARSSON, D. G. J. Effluent From Bulk Drug Production Is Toxic To Aquatic Vertebrates. Environmental Toxicology And Chemistry, 2009, 28, 2656-2662.

CUKLEV, F., KRISTIANSSON, E., FICK, J., ASKER, N., FORLIN, L. \& LARSSON, D. G. J. , Diclofenac In Fish: Blood Plasma Levels Similar To Human Therapeutic Levels Affect Global Hepatic Gene Expression. Environmental Toxicology and Chemistry, 30, 2011, $2126-2134$.

FICK, J., SODERSTROM, H., LINDBERG, R. H., PHAN, C., TYSKLIND, M. \& LARSSON, D. G. J. Contamination of surface, ground, and drinking water from pharmaceutical production. Env Tox \& Chem, 28, 2009, 2522-2527.

GUNNARSSON, L., KRISTIANSSON, E., RUTGERSSON, C., STURVE, J., FICK, J., FORLIN, L. \& LARSSON, D. G. J. Pharmaceutical Industry Effluent Diluted 1:500 Affects Global Gene Expression, Cytochrome P4501A Activity, And Plasma Phosphate In Fish. Environmental Toxicology And Chemistry, 28, 2009, 2639-2647.

HALLING-SORENSEN, B., NORS NIELSEN, S., LANSKY, P. F., INGERSLEV, F., HOLTEN LUTZHOFT, H. C. \& E, J. S. Occurrence, Fate, and Effects of Pharmaceutical Substances in the Environment- a Review. Chemosphere, 36, 1998, 357-393.

HAMSCHER, G., PAWELZICK, H. T., SCZESNY, S., NAU, H. \& HARTUNG, J. , Antibiotics in Dust Originating from a Pig-Fattening Farm: A New Source of Health Hazard for Farmers? Environ Health Perspect, 2003,111.

KRISTIANSSON, E., FICK, J., JANZON, A., GRABIC, R., RUTGERSSON, C., WEIJDEGA, B., SODERSTROM, H. \& LARSSON, D. G. J. , Pyrosequencing of Antibiotic-Contaminated River Sediments Reveals High Levels of Resistance and Gene Transfer Elements. PLoS One, 6, 2011, e17038. 
LARSSON, D. G. J., PEDRO, C. D. \& PAXEUS, N. , Effluent from drug manufactures contains extremely high levels of pharmaceuticals. Journal of hazardous materials, 148, 2007, 751-755.

RAMASWAMY, B. R., SHANMUGAM, G., VELU, G., RENGARAJA, B. \& LARSSON, B. D. G. GC-MS analysis and ecotoxicological risk assessment of triclosan, carbamazepine and parabens in Indian rivers. Journal of Hazardous Materials, 186,2011, $1586-1593$.

Sweden seeks GMP revisions to tackle environmental pollution, (July 2011) http://www.inpharm.com/news/162752/sweden-seeks-gmp-revisions$\underline{\text { tackle-environmental-pollution }}$

The Cost of Cheap Medicines: Antibiotic Pollution in Patancheru: ARC (July, 2010) http://anilcherukupalli.com/blog/2010/03/07/the-cost-ofcheap-medicines 


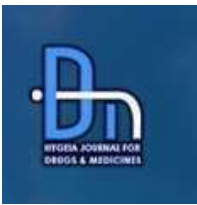

\title{
Synthesis and Analgesic activity studies of Simple new Aspirin Enkephalin analogues
}

\author{
J. Balamani ${ }^{*} \&$ M. Sekar ${ }^{2}$ \\ 1. Post Graduate and Research Department of Chemistry, Kongunadu Arts and Sciences College, Coimbatore-641 029, India. \\ 2. Post Graduate and Research Department of Chemistry, Sri Ramakrishna Mission, Vidyalaya College of Arts and Science, Coimbatore-641 020 India. \\ Article history: Received: 02 October, 2010, revised: 27 November, 2010, accepted: 23 July, 2011, Available online: 01 October 2011
}

\begin{abstract}
Aspirin amino acid amides 1(a-f), Aspirin dipeptide amides 2(a-f). tri peptide amides 3(a-f) and tetra peptide amides $\mathbf{4 a}$ and $\mathbf{4 c}$ were Synthesized. The synthesis of dipeptide amides were carried out in solution by stepwise elongation of the peptide chain from the C-terminal amino acid by coupling one amino acid at a time using DCC/HOBt method. The analgesic activity was studied by acetic acid induced writhing test. From the mean writhing values, it is evident that the entire sequence of the tetrapeptideamide namely, Gly-Gly-Phe-Met-NH $\mathrm{H}_{2}$ is essential for the observed analgesic activity of compound A. And, the entire sequence of the tetra peptide amide namely, Gly-Gly-Phe-Leu-NH $\mathrm{H}_{2}$ is essential for the observed analgesic activity of compound $C$. The decrease in analgesic activity of these compounds is in the order, aspirin tripepitide amides > aspirin dipeptide amides > aspirin amino acid amides.
\end{abstract}

Keywords: Aspirin, analgesic activity, amino acid amide, di, tri, and tetra peptides

\section{Introduction}

It has been found in our studies that the incorporation of inactive tetrapeptide amides of enkephalins into aspirin do not affect its peripherally medicated analgesic activity and interestingly has increased its potency by about 10 times.

It was now proposed to synthesize aspirin derivatives of aminoacid amides, dipeptide amides and tripeptide amides and study their analgesic activity. This is an attempt to know whether the entire tetra peptide amide sequence is responsible for its enhanced activity or any specific amino acid, dipeptide or tripeptide of the tetra peptide amide causes this enhancement. The following compounds were synthesized and their analgesic activity was studied.

Analgesics ${ }^{1}$ are drugs which relieve pain without causing loss of consciousness. Analgesic drugs act on the central and peripheral nervous systems and relieve pain by direct effects on pain and related path ways but do not affect the underlying pathology. The term "analgesic" covers only those agents which when administered systematically provide non-specific relief from pain without loss of consciousness by increasing the threshold of pain. 
Beluzzi et al ${ }^{2,3}$ reported the analgesic effect of Met- and Leu-enkephalins through injection into lateral ventricles of rats, using the tail flick procedure. This effect lasts only for a short duration and can be antagonized by naloxone.

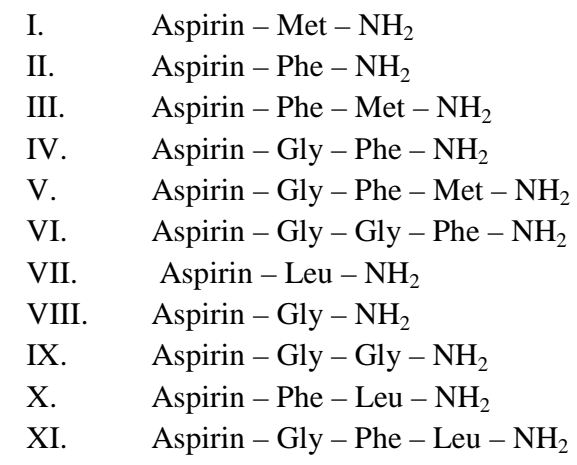

Both enkephalins are less potent than morphine. The lower potency of enkephalins and short duration of activity has been found to be due to the rapid cleavage of the Tyr1-Gly2 bond, by the action of enzymes present in brain. The biochemical role of the enkephalins is to inhibit the synthesis of the enzyme adenylcyclase. This enzyme catalyzes the conversion of 5'-adenosine triphosphate (ATP) to cyclic 3, 5' -adenosine monophosphate (cAMP).

It is assumed that the lowering of the level of cAMP which is accompanied by a simultaneous increase in the level of cyclic 3, $5^{\text {' }}$-guanine monophosphate (cGMP) is related to analgesia ${ }^{1}$

Enkephalins produced moderate to profound sedation and immobility, which can be prevented or reversed by naloxone. ${ }^{4,6}$ Leu-enkephalin elicits a contralateral rotational behavior, which cannot be prevented by naloxone. Enkephalins have received considerable attention as a result of the search for a drug with opiate-like activity and still be free of addiction liability ${ }^{7}$. Enkephalins induce dose-independent decrease in diastolic blood pressure and heart rate after intravenous administration of pentobarbitone anaesthetized $\operatorname{dogs}^{8}$. Enkephalins are also known to have antidiarrhoeal effects. ${ }^{9,10}$

\section{Enzymatic cleavage of Enkephalins}

All the four peptide bonds in enkephalins are known to be susceptible to the action of peptidases which cause rapid degradation. However, amino peptidases as well as enkephalinaseA are the only two well defined peptidases which are responsible for the physiological inactivation of the pentapeptides ${ }^{11,12}$.

The possible modes of degradation of enkephalin molecules are shown in figure below

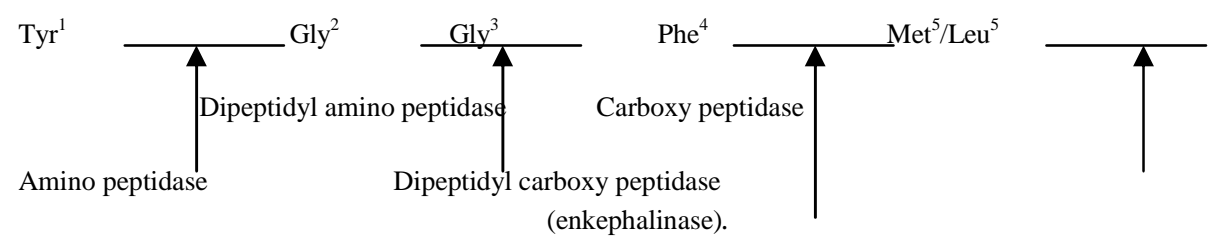


In enkephalins presence of Tyr in position 1 seems to be an absolute requirement, since enkephalins are hydrolysed by an aminopeptidase to give L-Tyrosine and Gly-Gly-Phe-Leu/Met, which are biologically inactive. Also loss of activity is observed on changing the L-tyrosyl to a D-tyrosyl configuration. These evidences show the tyrosyl residue is a key-binding element in enkephalin sequence..

Other studies such as masking the hydroxyl group in tyrosyl residue or removing it shows the loss of activity. Above proofs stress the idea that the tyrosyl residue and phenolic hydroxyl group are responsible for analgesia ${ }^{13}$

\section{Materials and Methods}

Aspirin was prepared by refluxing a freshly recrystallised sample of salicylic acid with a mixture of $\mathrm{Ac}_{2} \mathrm{O}$ and $\mathrm{AcOH}$.

Aspirin was coupled with tripeptide amide, dipeptide amide and aminoacid amide using its pnitrophenyl (Np) ester. Coupling of aspirin using DCC/HOBt was observed to be incomplete even after prolonged stirring. Thus, its aforementioned, ester was used for coupling. Aspirin p-nitro phenyl ester (Aspirin-ONp) was prepared by treating aspirin with 1.1 equivalent of p-nitrophenol in presence of DCC in EtOAc. Aspirin - ONp was precipitate using EtOH.

The synthesis of dipeptide and tripeptide amides were carried out in solution by stepwise elongation of the peptide chain from the c-terminal aminoacid by coupling one aminoacid at a time using DCC/HOBt method Boc group was used for $\mathrm{N}^{\alpha}$ protection of all aminoacids. The Bocgroup cleavage was carried out using 50\% TFA / $\mathrm{CH}_{2} \mathrm{Cl}_{2}$. The amidation of C-terminal aminoacids was carried out by treating the corresponding Boc-aminoacids with dry $\mathrm{NH}_{3}$ in presence of DCC and HOBt.

Then, Boc-aminoacid, Boc-aminoacid- $\mathrm{NH}_{2}$, Boc-dipeptide- $\mathrm{NH}_{2}$, Aspirin-dipeptide- $\mathrm{NH}_{2}$, Boctripeptide- $\mathrm{NH}_{2}$, Aspirin-tripeptide- $\mathrm{NH}_{2}$ are prepared as follows.

\subsection{Boc-Amino acids}

A mixture of amino acid (10 mmoles), Boc- $\mathrm{N}_{3}\left(2 \mathrm{ml}, 13\right.$ mmoles), $\mathrm{Et}_{3} \mathrm{~N}$ (3.4 ml, 25 mmoles) DMF $(4 \mathrm{ml})$ and water $(5 \mathrm{ml})$ was stirred at room temperature for $12-15 \mathrm{~h}$. Water $(50 \mathrm{ml})$ was added to the reaction mixture and extracted with ether $(3 \times 30 \mathrm{ml})$.

The aqueous phase was acidified with $\mathrm{KHSO}_{4}$ to $\mathrm{pH} 2$ and the liberated Boc-aminoacid was extracted into EtOAc $(3 \times 20 \mathrm{ml})$. The combined extracts were washed with water $(4 \times 30 \mathrm{ml})$, dried over $\mathrm{Na}_{2} \mathrm{SO}_{4}$ and evaporated in vacuo. The residue was crystallized using petroleum ether.

The yield, melting point and the $\mathrm{R}_{\mathrm{f}}$ values of the Boc-amino acid prepared are given below:

\begin{tabular}{lcccc}
\hline Boc-aminoacid & Yield & M.p. & \multicolumn{2}{c}{ Rf values } \\
& \% & ${ }^{\circ} \mathbf{C}$ & A & B \\
\hline Boc-Met & 91 & Oil & 0.64 & 0.67 \\
Boc-Phe & 83 & Oil & 0.59 & 0.63 \\
Boc-Gly & 88 & $87-88$ & 0.48 & 0.53 \\
Boc-Leu & 81 & $85-86$ & 0.61 & 0.73 \\
\hline
\end{tabular}




\subsection{Boc-aminoacid- $\mathrm{NH}_{2}$}

To a mixture of Boc-aminoacid (10 mmoles), $\mathrm{HOBt}$ (1.5g, 11 mmoles), in $\mathrm{CH}_{2} \mathrm{Cl}_{2}$ (40ml), and DMF $(10 \mathrm{ml})$, a solution of DCC $(2.1 \mathrm{~g}, 10.5 \mathrm{mmoles})$ in $\mathrm{CH}_{2} \mathrm{Cl}_{2}(20 \mathrm{ml})$ was added and stirred for $30 \mathrm{~min}$. Then dry $\mathrm{NH}_{3}$ was passed through the solution till saturation and stirred for 4-5h. The solvent was then evaporated in vacuo and the residue was diluted with EtOAc $(100 \mathrm{ml})$. A few drops of $\mathrm{AcOH}$ were added to destroy any unreacted DCC. The mixture was cooled and filtered to remove DCU. The filtrate was washed successively with $10 \%$ aq. $\mathrm{Na}_{2} \mathrm{CO}_{3}(3 \times 30 \mathrm{ml})$, water $(3 \times 30 \mathrm{ml}), 1 \mathrm{~N} \mathrm{HCl}(1 \times 30 \mathrm{ml})$, water $(3 \times 30 \mathrm{ml})$ and saturated $\mathrm{NaCl}(30 \mathrm{ml})$. It was then dried over $\mathrm{Na}_{2} \mathrm{So}_{4}$ and evaporated in vacuo. The residue was crystallized form petroleum ether.

The yield, melting points and $\mathrm{R}_{\mathrm{f}}$ values of the Boc-aminoacid-amides prepared are given below:

\begin{tabular}{lcccc}
\hline $\begin{array}{c}\text { Boc-aminoacid } \\
-\mathrm{NH}_{2}\end{array}$ & $\begin{array}{c}\text { Yield } \\
\%\end{array}$ & $\begin{array}{c}\text { M.p. } \\
{ }^{\circ} \mathrm{C}\end{array}$ & A & Rf values \\
\hline Boc-Met- $\mathrm{NH}_{2}$ & 86 & $109-111$ & 0.67 & 0.77 \\
Boc-Phe- $\mathrm{NH}_{2}$ & 92 & $120-122$ & 0.63 & 0.69 \\
Boc-Leu- $\mathrm{NH}_{2}$ & 87 & $139-141$ & 0.55 & 0.62 \\
Boc-Gly-NH & 82 & $115-117$ & 0.49 & 0.53 \\
& & & & \\
\hline
\end{tabular}

\subsection{Aspirin-aminoacid- $\mathrm{NH}_{2}$}

Boc-aminoacid- $\mathrm{NH}_{2}$ (5 mmoles) was deprotected by treating with a 1:1 mixture of TFA / $\mathrm{CH}_{2} \mathrm{Cl}_{2}(10 \mathrm{ml})$ for $30 \mathrm{~min}$ at room temperature. The solvent was removed under reduced pressure and the residue was treated with $5 \mathrm{M} \mathrm{HCl} / \mathrm{THF}(10 \mathrm{ml})$ for $30 \mathrm{~min}$ to get $\mathrm{HCl}$. Aminoacid- $\mathrm{NH}_{2}$. The solvent was removed under reduced pressure and the residue was dried over $\mathrm{KOH}$ pellets in vacuo.The above $\mathrm{HCl}$ salt was dissolved in dry $\mathrm{DMF}(10 \mathrm{ml})$ and neutralized with $\mathrm{Et}_{3} \mathrm{~N}$. To this a solution of aspirin-ONp (1.5, 5 mmoles) and $\mathrm{HOBt}\left(0.7 \mathrm{~g}, 5\right.$ mmoles) in $\mathrm{CH}_{2} \mathrm{Cl}_{2}$ (10ml) was added. The reaction mixture was stirred for $24 \mathrm{~h}$ at room temperature. TLC monitored the completion of the reaction.

The solvent was then evaporated under reduced pressure and the residue was diluted with EtOAc. Further workup process is same as given for Boc-aminoacid- $\mathrm{NH}_{2}$. Crystallization was done using petroleum ether.

The yield, melting points and $\mathrm{R}_{\mathrm{f}}$ values of the aspirin-amino acid- $\mathrm{NH}_{2}$ prepared are give below:

\begin{tabular}{|c|c|c|c|c|}
\hline \multirow[t]{2}{*}{ Asp-aminoacid - $\mathrm{NH}_{2}$} & \multirow{2}{*}{$\begin{array}{c}\text { Yield } \\
\%\end{array}$} & \multirow{2}{*}{$\begin{array}{c}\text { M.p. } \\
{ }^{\circ} \mathrm{C}\end{array}$} & \multicolumn{2}{|c|}{ Rf values } \\
\hline & & & A & B \\
\hline Aspirin-Met-NH ${ }_{2}$ (I) & 88 & $175-177$ & 0.57 & 0.63 \\
\hline Aspirin-Phe- $\mathrm{NH}_{2}$ (II) & 87 & $176-178$ & 0.61 & 0.66 \\
\hline Aspirin-Leu-NH ${ }_{2}$ (VII) & 81 & $171-173$ & 0.58 & 0.64 \\
\hline Aspirin-Gly- $\mathrm{NH}_{2}$ (VIII) & 70 & $173-175$ & 0.63 & 0.73 \\
\hline
\end{tabular}




\subsection{Boc-dipeptide-amide}

Boc-aminoacid-NH2 (5 mmoles) was deprotected by treating with a 1:1 mixture of TFA / $\mathrm{CH} 2 \mathrm{Cl} 2(10 \mathrm{ml})$ for $30 \mathrm{~min}$ at room temperature.

The solvent was removed under reduced pressure and the residue was treated with $5 \mathrm{M} \mathrm{HCl} / \mathrm{THF}$ $(10 \mathrm{ml})$ for $30 \mathrm{~min}$ to get $\mathrm{HCl}$. Dipeptide- $\mathrm{NH}_{2}$. The solvent was removed under reduced pressure and the residue was dried over $\mathrm{KOH}$ pellets in vacuo.

The above $\mathrm{HCl}$ salt was dissolved in dry DMF $(10 \mathrm{ml})$ and neutralized with $\mathrm{Et}_{3} \mathrm{~N}$. To this a solution of Boc-aminoacid (5 mmoles) and $\mathrm{HOBt}(0.7 \mathrm{~g}, 5 \mathrm{mmoles})$ in $\mathrm{CH}_{2} \mathrm{Cl}_{2}(20 \mathrm{ml})$ was added.

This mixture was cooled to $0^{\circ} \mathrm{C}$ and a cold solution of DCC (1g, 5 mmoles) in $\mathrm{CH}_{2} \mathrm{Cl}_{2}(10 \mathrm{ml})$ was added dropwise under stirring. The reaction mixture was the stirred for about $1 \mathrm{~h}$ at $0^{\circ} \mathrm{C}$ and for about $15 \mathrm{~h}$ at room temperature. TLC monitored the completion of the reaction. The solvent was then evaporated under reduced pressure and the residue was diluted with EtOAc. Further workup process is same as given for Boc-aminoacid- $\mathrm{NH}_{2}$. Crystallization was done using petroleum ether.

The yield, melting point and $\mathrm{R}_{\mathrm{f}}$ values of the Boc-dipeptide- $\mathrm{NH} 2$ prepared are given below:

\begin{tabular}{|c|c|c|c|c|}
\hline \multirow{2}{*}{ Boc-aminoacid - $\mathrm{NH}_{2}$} & \multirow{2}{*}{$\begin{array}{c}\text { Yield } \\
\%\end{array}$} & \multirow{2}{*}{$\begin{array}{c}\text { M.p. } \\
{ }^{\circ} \mathrm{C}\end{array}$} & \multicolumn{2}{|c|}{ Rf values } \\
\hline & & & A & B \\
\hline Boc-Phe-Met-NH ${ }_{2}$ & 80 & $118-120$ & 0.76 & 0.83 \\
\hline Boc-Gly-Phe-NH ${ }_{2}$ & 81 & 144-146 & 0.71 & 0.75 \\
\hline Boc-Phe-Leu-NH ${ }_{2}$ & 81 & $165-167$ & 0.53 & 0.61 \\
\hline Boc-Gly-Gly-NH & 71 & $136-138$ & 0.46 & 0.54 \\
\hline Boc-Gly-Met-NH ${ }_{2}$ & 78 & $145-147$ & 0.67 & 0.71 \\
\hline
\end{tabular}

\subsection{Aspirin-dipeptide- $\mathrm{NH}_{2}$}

Boc-dipeptide- $\mathrm{NH}_{2}$ (5 mmoles) was deprotected by treating with a $1: 1$ mixture of $\mathrm{TFA} / \mathrm{CH}_{2} \mathrm{Cl}_{2}$ $(10 \mathrm{ml})$ for $30 \mathrm{~min}$ at room temperature. The solvent was removed under reduced pressure and the residue was treated with $5 \mathrm{M} \mathrm{HCl} / \mathrm{THF}(10 \mathrm{ml})$ for $30 \mathrm{~min}$ to get $\mathrm{HCl}$. dipeptide- $\mathrm{NH}_{2}$. The solvent was removed under reduced pressure and the residue was dried over $\mathrm{KOH}$ pellets in vacuo.

The above $\mathrm{HCl}$ salt was dissolved in dry DMF $(10 \mathrm{ml})$ and neutralized with $\mathrm{Et}_{3} \mathrm{~N}$. To this a solution of aspirin-ONp (1.5g, 5 mmoles) and $\mathrm{HOBt}(0.7 \mathrm{~g}, 5 \mathrm{mmoles})$ in $\mathrm{CH}_{2} \mathrm{Cl}_{2}$ (10ml) was added. The reaction mixture was stirred for $24 \mathrm{~h}$ at room temperature. TLC monitored the completion of the reaction. The solvent was then evaporated under reduced pressure and the residue was diluted with EtOAc. Further workup process is same as given for Boc-aminoacid$\mathrm{NH}_{2}$. Crystallization was done using petroleum ether. 
The yield, melting point and $\mathrm{R}_{\mathrm{f}}$ values of the aspirin-dipeptide- $\mathrm{NH}_{2}$ prepared are given below:

\begin{tabular}{|c|c|c|c|c|}
\hline \multirow[t]{2}{*}{ Asp-dipeptide $\mathrm{NH}_{2}$} & \multirow{2}{*}{$\begin{array}{c}\text { Yield } \\
\%\end{array}$} & \multirow{2}{*}{$\begin{array}{c}\text { M.p. } \\
{ }^{\circ} \mathrm{C}\end{array}$} & \multicolumn{2}{|c|}{ Rf values } \\
\hline & & & $\mathbf{A}$ & B \\
\hline Aspirin-Phe-Met-NH ${ }_{2}$ (III) & 82 & $172-174$ & 0.54 & 0.59 \\
\hline Aspirin-Gly-Phe-NH ${ }_{2}$ (IV) & 83 & $173-175$ & 0.56 & 0.61 \\
\hline Aspirin-Phe-Leu- $\mathrm{NH}_{2}(\mathrm{x})$ & 81 & $171-173$ & 0.59 & 0.65 \\
\hline Aspirin-Gly-Gly- $\mathrm{NH}_{2}$ (IX) & 77 & $176-178$ & 0.54 & 0.61 \\
\hline
\end{tabular}

\subsection{Boc-tripeptide- $\mathrm{NH}_{2}$}

Boc-dipeptide- $\mathrm{NH}_{2}(5$ mmoles $)$ was deprotected by treating with a 1:1 mixture of TFA / $\mathrm{CH}_{2} \mathrm{Cl}_{2}$ $(10 \mathrm{ml})$ for $30 \mathrm{~min}$ at room temperature. The solvent was removed under reduced pressure and the residue was treated with $5 \mathrm{M} \mathrm{HCl} / \mathrm{THF}(10 \mathrm{ml})$ for $30 \mathrm{~min}$ to get $\mathrm{HCl}$.dipeptide- $\mathrm{NH}_{2}$. The solvent was removed under reduced pressure and the residue was dried over $\mathrm{KOH}$ pellets in vacuum.

The above $\mathrm{HCl}$ salt was dissolved in dry DMF $(10 \mathrm{ml})$ and neutralized with Et3N. To this a solution of Boc-aminoacid (5 mmoles) and $\mathrm{HOBt}\left(0.7 \mathrm{~g}, 5\right.$ mmoles) in $\mathrm{CH}_{2} \mathrm{Cl}_{2}$ (20ml) was added. This mixture was cooled to $0^{\circ} \mathrm{C}$ and a cold solution of DCC (1g, 5 mmoles) in $\mathrm{CH}_{2} \mathrm{Cl}_{2}(10 \mathrm{ml})$ was added dropwise under stirring. The reaction mixture was then stirred for about $1 \mathrm{~h}$ at $0^{\circ} \mathrm{C}$ and for about $15 \mathrm{~h}$ at room temperature. TLC monitored the completion of the reaction. The solvent was then evaporated under reduced pressure and the residue was diluted with EtOAc. Further workup process is same as given for Boc-aminoacid- $\mathrm{NH}_{2}$. Crystallization was done using petroleum ether.

The yield, melting point and $\mathrm{R}_{\mathrm{f}}$ values of the Boc-tripeptide- $\mathrm{NH}_{2}$ prepared are given below:

\begin{tabular}{|c|c|c|c|c|}
\hline \multirow[t]{2}{*}{ Boc-tripeptide $-\mathrm{NH}_{2}$} & \multirow{2}{*}{$\begin{array}{c}\text { Yield } \\
\%\end{array}$} & \multirow{2}{*}{$\begin{array}{c}\text { M.p. } \\
{ }^{\circ} \mathrm{C}\end{array}$} & \multicolumn{2}{|c|}{ Rf values } \\
\hline & & & $\mathbf{A}$ & $\mathbf{B}$ \\
\hline Boc-Gly-Phe-Met-NH ${ }_{2}$ & 91 & $145-147$ & 0.59 & 0.64 \\
\hline Boc-Gly-Gly-Phe-NH ${ }_{2}$ & 86 & $166-168$ & 0.55 & 0.62 \\
\hline Boc-Gly-Phe-Leu-NH ${ }_{2}$ & 82 & $165-167$ & 0.63 & 0.68 \\
\hline Boc-Gly-Gly-Met- $\mathrm{NH}_{2}$ & 83 & $165-167$ & 0.74 & 0.70 \\
\hline
\end{tabular}

\subsection{Aspirin-tripeptide- $\mathrm{NH}_{2}$}

Boc-tripeptide- $\mathrm{NH}_{2}$ (5 mmoles) was deprotected by treating with a 1:1 mixture of TFA/ $\mathrm{CH}_{2} \mathrm{Cl}_{2}$ $(10 \mathrm{ml})$ for $30 \mathrm{~min}$ at room temperature. The solvent was removed under reduced pressure and the residue was treated with $5 \mathrm{M} \mathrm{HCl} / \mathrm{THF}(10 \mathrm{ml})$ for $30 \mathrm{~min}$ to get $\mathrm{HCl}$. tripeptide- $\mathrm{NH}_{2}$. The solvent was removed under reduced pressure and the residue was dried over $\mathrm{KOH}$ pellets in vacuo.

The above $\mathrm{HCl}$ salt was dissolved in dry DMF $(10 \mathrm{ml})$ and neutralized with $\mathrm{Et}_{3} \mathrm{~N}$. To this a solution of aspirin-ONp (1.5g, 5 mmoles) and $\mathrm{HOBt}\left(0.7 \mathrm{~g}, 5\right.$ mmoles) in $\mathrm{CH}_{2} \mathrm{Cl}_{2}$ (10ml) was added. The reaction mixture was stirred for $24 \mathrm{~h}$ at room temperature. 


\section{Scheme of synthesis}

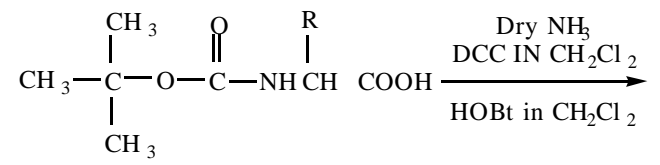

Boc - amino acid $1(a-b)$

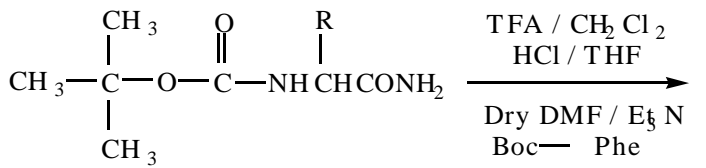

Boc - aminoacid amide 2( $\mathrm{a}-\mathrm{b})$
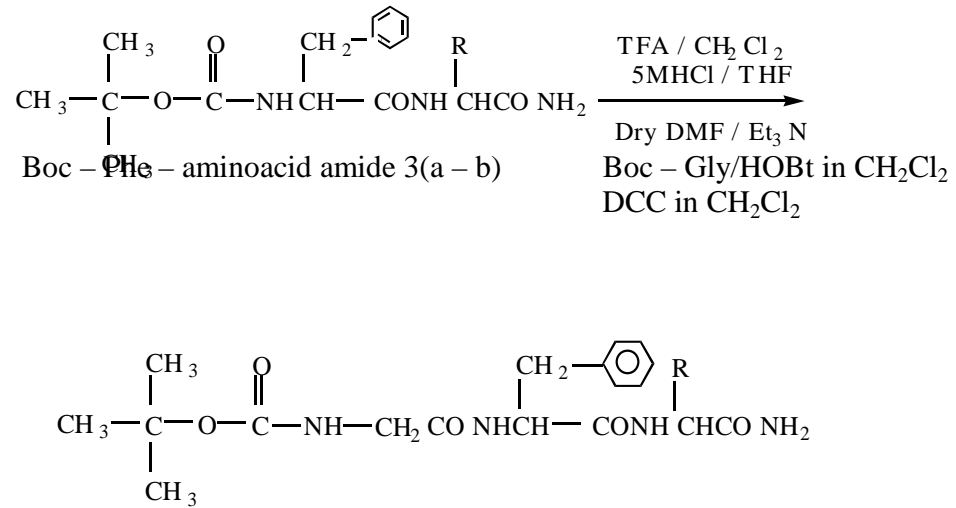

Boc - Gly - Phe - aminoacid amide 4 $(\mathrm{a}-\mathrm{b})$

TFA / $\mathrm{CH}_{2} \mathrm{Cl}_{2}$

$5 \mathrm{MHCl}$

Dry DMF / Et ${ }_{3} \mathrm{~N}$

Boc - Gly / HOBt in $\mathrm{CH}_{2} \mathrm{Cl}_{2}$

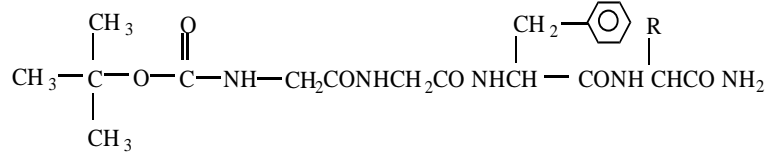

Boc - Gly - Gly - Phe - aminoacid amide 5 ( $a-b)$
}

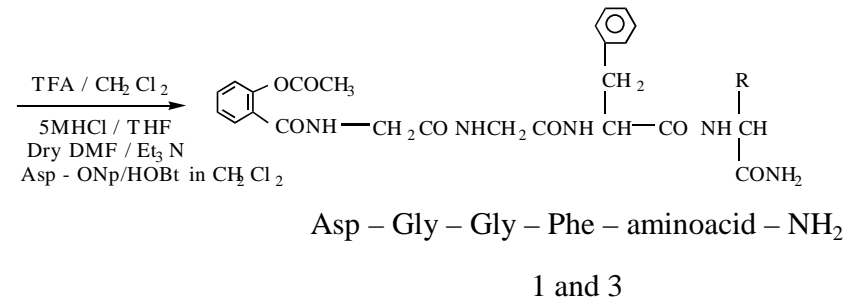




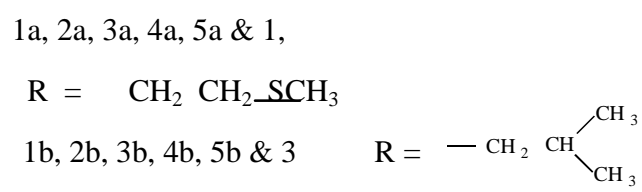

TLC monitored the completion of the reaction. The solvent was then evaporated under reduced pressure and the residue was diluted with EtOAc. Further workup process is same as given for Boc-aminoacid- $\mathrm{NH}_{2}$.

The yield, melting point and $\mathrm{R}_{\mathrm{f}}$ values of the aspirin-tripeptide- $\mathrm{NH}_{2}$ prepared are given below:

\begin{tabular}{|c|c|c|c|c|}
\hline \multirow{2}{*}{ Aspirin-tripeptide- $\mathrm{NH}_{2}$} & \multirow{2}{*}{$\begin{array}{c}\text { Yield } \\
\%\end{array}$} & \multirow{2}{*}{$\begin{array}{c}\text { M.p. } \\
{ }^{\circ} \mathbf{C}\end{array}$} & \multicolumn{2}{|c|}{ Rf values } \\
\hline & & & $\mathbf{A}$ & B \\
\hline Aspirin-Gly-Phe-Met- $\mathrm{NH}_{2}$ (V) & 78 & $175-177$ & 0.56 & 0.60 \\
\hline Aspirin-Gly-Gly-Phe-NH ${ }_{2}(\mathrm{Vi})$ & 82 & $170-172$ & 0.56 & 0.62 \\
\hline Aspirin-Gly-Phe-Leu-NH ${ }_{2}(\mathrm{XI})$ & 78 & $170-173$ & 0.61 & 0.66 \\
\hline
\end{tabular}

The Structures of compounds A, C, I to XI were confirmed by IR, NMR Data and elemental analysis.

\section{Acetic acid induced writhing test}

Analgesic effects of the compounds were studied using $\mathrm{ACOH}$-inducing writhing in mice. The mouse weighing 25-30g was separated into 25 groups of 5 each. The animal studies were conducted according to the institutional animal ethical committee (IAEC) and CPCSEA guidelines, (No.659/02/a/CPCSEA).After 18h fasting, the test was conducted as follows: $0.5 \%$ carboxymethyl cellulose was administered orally to one group of mouse considered as control. Another gp was administered orally with aspirin $(100 \mathrm{mg} / \mathrm{kg}$ body, weight) and the seven gps were administered orally with compounds I to VI (100mg/kg body weight).

Compound 'Aspirin - Gly - Gly - Phe - Met $-\mathrm{NH}_{2}(\mathrm{~A})$ is the standard. Another six groups were administered orally with compounds VII to XI (100mg/kg body weight). Compound Asp - Gly Gly - Phe - Leu - $\mathrm{NH}_{2}(\mathrm{C})$ is the standard and the remaining ten groups were administered orally with compounds (1) to (10). An hour after administration of standard and analogues, $\mathrm{AcOH}(1 \%)$ $\mathrm{v} / \mathrm{v}(1 \mathrm{ml} / 100 \mathrm{~g}$ body weight) was injected intraperitonially. Then the number of writhing responses of each mouse in a group was noted during a period of $1 \mathrm{~h}$ and mean writhing scores of each group was calculated.

\section{Results and discussion}

The present work was carried out with the aim of studying structure activity relationship in Aspirin-Gly-Gly-Phe-Met- $\mathrm{NH}_{2}$ (A). Six compounds incorporating aminoacid amide, dipeptide amide and tripeptide amide related to $\mathrm{A}$ were synthesized. Their analgesic activity was determined and compared with that of A. 
Aspirin prepared using the reported procedure could be obtained in highly pure form after recrystallaization twice or thrice in hot water. The dipeptide sequences Boc-Phe-Met- $\mathrm{NH}_{2}$, BocGly-Phe- $\mathrm{NH}_{2}$ and the tripepitide sequences Boc-Gly-Phe-Met- $\mathrm{NH}_{2}$, Boc-Gly-Gly-Phe- $\mathrm{NH}_{2}$ were synthesized by $\mathrm{DCC} / \mathrm{HOBt}$ method and were obtained in good yield and purity.

The glycine aminoacid sample that usually contains small quantities of glycylglycine was removed after $\mathrm{N}^{\alpha}$ protection using Boc group by using column packed with silica gel and solvent system(a) chloroform : methanol : acetic acid (40:2:1). Aspirin-ONp and Boc-aminoacids were prepared using the reported procedure. Boc-Met- $\mathrm{NH}_{2}$ and Boc-Phe- $\mathrm{NH}_{2}$ were prepared using Boc-Met or Boc-Phe / dry $\mathrm{NH}_{3}$ / DCC / $\mathrm{HOBt}$ and was obtained in about $87 \%$ yield.

The structure of Boc-Met, Boc-Met- $\mathrm{NH}_{2}$, Boc-Phe, Boc-Phe- $\mathrm{NH}_{2}$, Boc-Gly, Boc-Gly-NH $\mathrm{N}_{2}$, BocLeu, Boc-Leu- $\mathrm{NH}_{2}$, were confirmed by IR data. The structure of $\mathrm{A}$ and $\mathrm{C}$ were confirmed by ${ }^{1} \mathrm{H}$ NMR Spectral date.

Boc-Met: The IR Spectrum of Boc-Met shows a broad band around $3345 \mathrm{~cm}^{-1}$, which may be due to $\mathrm{O}-\mathrm{H}$ stretching of carboxyl group. The N-H stretching of the secondary amide expected in the range of $3300-3100 \mathrm{~cm}^{-1}$, might have superimposed with $\mathrm{O}-\mathrm{H}$ stretching. The bands at 2578 and at $2372 \mathrm{~cm}^{-1}$ may be due to $\mathrm{C}-\mathrm{H}$ stretching. The sharp band at $1720 \mathrm{~cm}^{-1}$ may corresponds to the $\mathrm{C}=\mathrm{O}$ stretching of carboxyl group and the band at $1652 \mathrm{~cm}^{-1}$ may corresponds to the $\mathrm{C}=\mathrm{O}$ stretching in secondary amide. The $\mathrm{N}-\mathrm{H}$ bending bands might have superimposed on the $\mathrm{C}=\mathrm{O}$ stretching. The IR Spectrum of this compound is given in Table 1.

Boc-Met-NH $:$ In this spectrum no broad band occurs at $3345 \mathrm{~cm}^{-1}$. This shows the absence of O-H group.

Two sharp bands at 3390 and $3188 \mathrm{~cm}^{-1}$ observed may correspond to the asymmetric and symmetric $\mathrm{N}-\mathrm{H}$ stretching frequencies of the primary amide. The sharp band at $3342 \mathrm{~cm}^{-1}$ may be due to the N-H stretching of the secondary amide.

The bands at 2927 and $2850 \mathrm{~cm}^{-1}$ may corresponding to C-H stretching frequencies. Some of the $\mathrm{C}-\mathrm{H}$ stretching might have superimposed. The bands at 1678 and $1658 \mathrm{~cm}^{-1}$ may be due to $\mathrm{C}=\mathrm{O}$ stretching.

Boc-Leu-NH2: In this spectrum no broad band occurs at $3345 \mathrm{~cm}^{-1}$. This shows the absence of O$\mathrm{H}$ group. Two sharp bands at 3405 and $3180 \mathrm{~cm}^{-1}$ observed may correspond to the asymmetric and symmetric N-H stretching frequencies of the primary amide.

Boc-Leu:The IR spectrum of Boc-Leu shows a broad band around $3345 \mathrm{~cm}^{-1}$, which may be due to $\mathrm{O}-\mathrm{H}$ stretching of carboxyl group. The $\mathrm{N}-\mathrm{H}$ stretching of the secondary amide expected in the range of $3300-3100 \mathrm{~cm}^{-1}$, might have superimposed with $\mathrm{OH}$-stretching. The bands at 2950, 2850 and $2560 \mathrm{~cm}^{-1}$ may be due to $\mathrm{C}-\mathrm{H}$ stretching in $-\mathrm{CH}_{2}$ and $-\mathrm{CH}$ groups. 
The sharp band at $1725 \mathrm{~cm}^{-1}$ may corresponds to the $\mathrm{C}=\mathrm{O}$ stretching of carboxyl group and the band at $1655 \mathrm{~cm}^{-1}$ may corresponds to the $\mathrm{C}=\mathrm{O}$ stretching in secondary amide. The $\mathrm{N}-\mathrm{H}$ bending bands might have superimposed on the $\mathrm{C}=\mathrm{O}$ stretching. The IR spectrum of this compound is given in Table 2.

Table. 1 IR Spectral data $\left(v\right.$ in $\left.\mathrm{cm}^{-1}\right)$

\begin{tabular}{|c|c|c|c|c|}
\hline Compound & 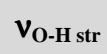 & $V_{\mathrm{N}-\mathrm{H} \text { str }}$ & $v_{\mathrm{C}-\mathrm{H} \text { str }}$ & $V_{C=O}$ str \\
\hline Boc-Met & 3345 & $\begin{array}{c}\text {-CONH-superimposed on } \\
\text { O-H } \\
\text { stretching }\end{array}$ & $\begin{array}{l}2578 \\
2372\end{array}$ & $\begin{array}{c}-\mathrm{COOH}- \\
1720 \\
-\mathrm{CONH}- \\
1652\end{array}$ \\
\hline Boc-Met- $\mathrm{NH}_{2}$ & --- & $\begin{array}{c}-\mathrm{CONH}_{2} 3390, \text { asym } 3188, \\
\text { symm } \\
-\mathrm{CONH}-3342\end{array}$ & $\begin{array}{l}2927 \\
2850\end{array}$ & $\begin{array}{c}-\mathrm{CONH}- \\
1658 \\
-\mathrm{CONH} \\
1678\end{array}$ \\
\hline
\end{tabular}

Table. 2 IR Spectral data $\left(v\right.$ in $\left.\mathrm{cm}^{-1}\right)$

\begin{tabular}{|c|c|c|c|c|}
\hline Compound & $\mathbf{V}_{\text {O-H Str }}$ & $\mathbf{v}_{\mathrm{N}-\mathrm{H} \text { Str }}$ & $v_{\text {C-H Str }}$ & $\mathbf{V}_{\mathrm{C}=\mathbf{O} \text { Str }}$ \\
\hline Boc-Leu & 3345 & $\begin{array}{c}\text {-CONH- } \\
\text { superimposed } \\
\text { on } \mathrm{O}-\mathrm{H} \\
\text { stretching }\end{array}$ & $\begin{array}{c}2950 \\
2850 \\
\text { aromatic ring; } \\
2560\end{array}$ & $\begin{array}{c}-\mathrm{COOH}- \\
1725 \\
-\mathrm{CONH}- \\
1655\end{array}$ \\
\hline Boc-Leu-NH ${ }_{2}$ & --- & $\begin{array}{c}-\mathrm{CONH}_{2} \\
3405, \text { asym } \\
3180, \text { symm } \\
\text {-CONH- } \\
3325\end{array}$ & $\begin{array}{l}2945 \\
2875\end{array}$ & $\begin{array}{c}-\mathrm{CONH}- \\
1642 \\
-\mathrm{CONH}_{2} \\
1675\end{array}$ \\
\hline
\end{tabular}

The sharp band at $3325 \mathrm{~cm}^{-1}$ may be due to the N-H stretching of the secondary amide. The bands at 2945 and $2875 \mathrm{~cm}^{-1}$ may correspond to $\mathrm{C}-\mathrm{H}$ stretching frequencies. Some of the $\mathrm{C}-\mathrm{H}$ stretching might have superimposed. The bands at 1675 and $1642 \mathrm{~cm}^{-1}$ may be due to $\mathrm{C}=\mathrm{O}$ stretching frequencies corresponding to the primary and secondary amide. The $\mathrm{v}_{\mathrm{C}=\mathrm{O}}$ stretch which appears at $1720 \mathrm{~cm}^{-1}$ in the carboxyl group of Boc-Leu may now be appearing at a lower frequency of $1675 \mathrm{~cm}^{-1}$ due to the $+\mathrm{M}$ effect of primary amide group. 
The above pattern of bands thus confirms the conversion of Boc-Leu to Boc-Leu-NH $\mathrm{NH}_{2}$. The IR spectrum of this compound is given in Table 2 .

The structures of compounds I to XI were given as below:

Aspirin-Met- $\mathrm{NH}_{2}$ (I)

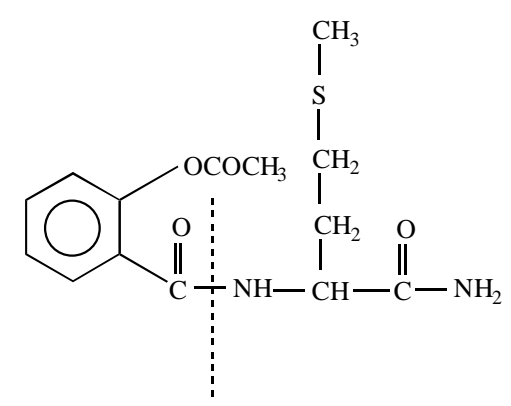

Aspirin-Phe- $\mathrm{NH}_{2}$ (II)<smiles>NC(=O)C(Cc1ccccc1)NC(=O)c1ccccc1OC(=O)O</smiles>

Aspirin-Phe-Met-NH 2 (III)

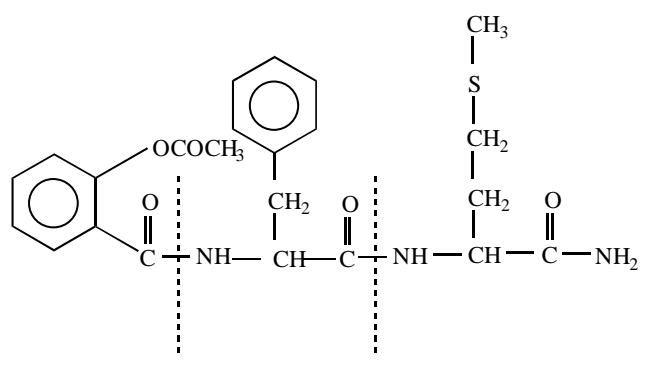

Aspirin-Gly-Phe- $\mathrm{NH}_{2}$ (IV)

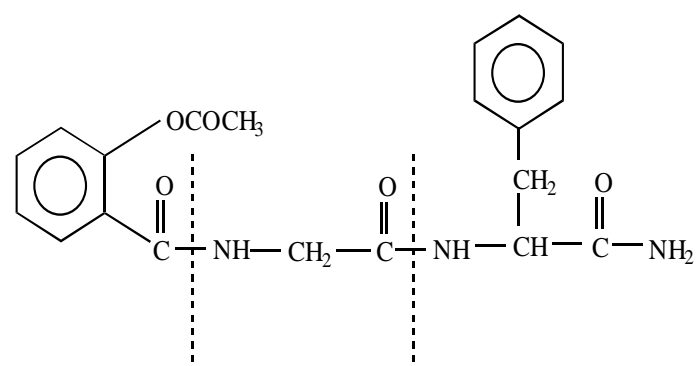

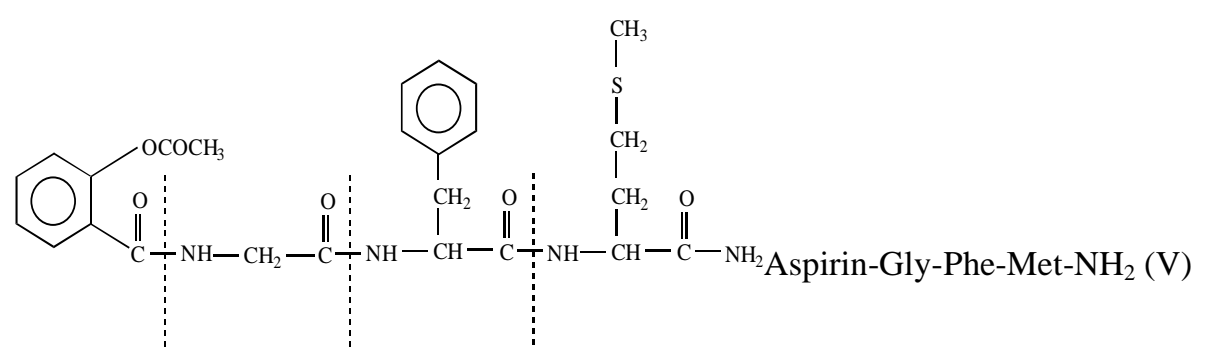<smiles>CC(=O)Oc1ccccc1C(=O)NC(CC(C)C)C(N)=O</smiles> 
Aspirin-Gly- $\mathrm{NH}_{2}$ (VIII)<smiles>CC(=O)Oc1ccccc1C(=O)I(I)NCN</smiles>

Aspirin-Gly-Gly- $\mathrm{NH}_{2}(\mathrm{X})$<smiles>CC(=O)Oc1ccccc1C(=O)NCC(=O)NCC(N)=O</smiles>

Aspirin-Phe-Leu- $\mathrm{NH}_{2}$ (IX)<smiles>CC(=O)Oc1ccccc1C(=O)NC(Cc1ccccc1)C(=O)N[14C](I)[C@H](I)C(N)=O</smiles>

\subsection{Data pertaining to a few selected compounds are as follows:}

\section{A. Asp-Gly-Gly-Phe-Met-NH}

M.Pt. $\left(175-178^{\circ} \mathrm{C}\right)$;

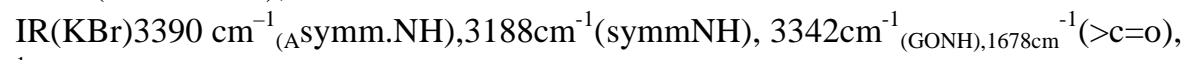

${ }^{1} \mathrm{HNMR} ;(400 \mathrm{MHZ})\left(\mathrm{DMSO}-\mathrm{d}_{6}\right) \delta 2.27\left(-\mathrm{COCH}_{3}\right), \delta 7.8(-\mathrm{NH}-)$ and $\delta 8.4\left(-\mathrm{NH}_{2}\right)$;

Elemental analysis: Glycyl - Glycyl - phenylalanyl - Methionine amide of Aspirin. $\mathrm{C}_{27} \mathrm{H}_{33} \mathrm{O}_{7} \mathrm{~N}_{5} \mathrm{~S}$ (571) is found to have $\mathrm{C} 56.74 \%, \mathrm{H}=5.78 \%$ and $\mathrm{N} 12.26 \%$; calculated $\mathrm{C} 56.71 \% \mathrm{H} 5.32 \%$ and $\mathrm{N} 11.75 \%$.

\section{Asp-Gly-Gly-Phe-Leu-NH ${ }_{2}:-$}

M.Pt(165 to $168^{\circ}$ C); IR(KBr);3394 $\mathrm{cm}^{-1}{ }_{(A}$ symm.NH), $3207 \mathrm{~cm}^{-1}$ (symm.NH), $3351 \mathrm{~cm}^{-1}(\mathrm{GONH}), 1717 \mathrm{~cm}^{-1}(>\mathrm{c}=\mathrm{O})$,

${ }^{1} \mathrm{HNMR} ;(400 \mathrm{MHZ})\left(\mathrm{DMSO}_{\mathrm{d}}\right)$ $) \delta 2.5\left(-\mathrm{COCH}_{3}\right), \delta 8(-\mathrm{NH}-)$ and $\delta 7.95\left(-\mathrm{NH}_{2}\right)$;

Elemental analysis: Glycyl - Glycyl - phenylalanyl - Leucine amide of Aspirin.

$\mathrm{C}_{28} \mathrm{H}_{35} \mathrm{O}_{7} \mathrm{~N}_{5}(553)$ is found to have $\mathrm{C} 60.76 \%, \mathrm{H}=6.33 \%$ and $\mathrm{N} 12.66 \%$;

calculated C $60.2 \% \mathrm{H} 5.98 \%$ and $\mathrm{N} 12.32 \%$.

\section{Boc- Methionine (Boc-Met)}

M.Pt. $109-111^{\circ} \mathrm{C}$; IR (KBr); $3394 \mathrm{~cm}^{-1}$ (asymmetric NH), $3207 \mathrm{~cm}^{-1}$ (sym. NH), $3351 \mathrm{~cm}^{-1}$ (-CONH)., $1717 \mathrm{~cm}^{-1},(>\mathrm{C}=\mathrm{O})$,

${ }^{1} \mathrm{HNMR} ;(400 \mathrm{MHz})\left(\mathrm{DMSO}_{-} \mathrm{d}_{6}\right) ; \delta 2.5\left(-\mathrm{COCH}_{3}\right), \delta 8(\mathrm{~N}-\mathrm{H})$ and $\delta 7.95\left(-\mathrm{NH}_{2}\right)$.

Elemental analysis: $\mathrm{C}_{10} \mathrm{H}_{19} \mathrm{O}_{4} \mathrm{~S}$ (235) is found to have $\mathrm{C} 51.06 \%, \mathrm{H}=8.09 \%$ and $\mathrm{S} 13.62 \%$; calculated $\mathrm{C}$ $50.9 \% \mathrm{H} 9.12 \%$ and $\mathrm{S} 12.9 \%$.

\section{Boc-Leucine (Boc-Leu)}

M.P. $85-88^{\circ}$ C; IR (KBr); $3390 \mathrm{~cm}^{-1}$ (Asymm.NH); $3188 \mathrm{~cm}^{-1}$ (symm.NH)., $3342 \mathrm{~cm}^{-1}$ (CONH), $1678 \mathrm{~cm}^{-1}$ $(>\mathrm{C}=\mathrm{O})$,

${ }^{1} \mathrm{H}$ NMR: $\delta 2.27 \quad\left(-\mathrm{COCH}_{3}\right), \delta 8.2(-\mathrm{NH}-) \delta 8.4\left(-\mathrm{NH}_{2}\right)$.

Elemental analysis: $\mathrm{C}_{11} \mathrm{H}_{21} \mathrm{O}_{4}(195)$ is found to have $\mathrm{C} 67.69 \%, \mathrm{H}=10.77 \%$ and $\mathrm{O} 32.82 \%$; calculated $\mathrm{C}$ $66.9 \% \mathrm{H} 10.12 \%$ and $\mathrm{O} 31.93 \%$. 
${ }^{1} \mathrm{H}$ NMR parameters of the aminoacid residues (A) and (C) are Asp - Gly (1) - Gly (2) - Phe (3) - X (4) - $\mathrm{NH}_{2}$

\begin{tabular}{|c|c|c|c|}
\hline Groups & Parameters & $\begin{array}{l}\text { X(4) } \\
\text { Leu }\end{array}$ & $\begin{array}{l}\text { X(4) } \\
\text { Met }\end{array}$ \\
\hline \multirow[t]{2}{*}{ Gly (1) } & $\delta \mathrm{NH}$ & 8.21 & 8.2 \\
\hline & $\delta \mathrm{CH}_{2}$ & 3.2 & 3.4 \\
\hline \multirow[t]{2}{*}{ Gly (2) } & $\delta \mathrm{NH}$ & 8 & 7.8 \\
\hline & $\delta \mathrm{CH}_{2}$ & 3.06 & 3.1 \\
\hline \multirow[t]{4}{*}{ Phe (3) } & $\delta \mathrm{NH}$ & 8 & 8 \\
\hline & $\delta \mathrm{C}^{\alpha} \mathrm{H}$ & 4.5 & 5.3 \\
\hline & $\delta \mathrm{CH}_{2}$ & 3.6 & 3.4 \\
\hline & $\delta \mathrm{C}_{6} \mathrm{H}_{5}$ & 7.3 & 7.25 \\
\hline$-\mathrm{NH}_{2}$ & $\delta$ & 7.95 & 8.4 \\
\hline$-\mathrm{COCH}_{3}$ & $\delta$ & 2.5 & 2.27 \\
\hline
\end{tabular}

The methyl resonance of methionine at $2.04 \mathrm{ppm}$, the isopropyl resonance of leucine at $4.5 \mathrm{ppm}^{14}$.

The result of the analgesic activity studies carried out for the compounds using AcOH induced writhing test are given below:

\begin{tabular}{|c|c|c|c|c|c|c|c|}
\hline \multirow[t]{2}{*}{ S.No } & \multirow[t]{2}{*}{ Compound } & \multicolumn{5}{|c|}{ Writhing response for $1 \mathrm{~h}$} & \multirow[t]{2}{*}{ Mean } \\
\hline & & 1 & 2 & 3 & 4 & 5 & \\
\hline 1. & Control & 69 & 65 & 63 & 67 & 68 & 66.4 \\
\hline 2. & Aspirin & 15 & 12 & 11 & 13 & 14 & 13.0 \\
\hline 3. & Aspirin-Gly-Gly-Phe-Met- $\mathrm{NH}_{2}(\mathrm{~A})$ & 1 & 0 & 1 & 1 & 0 & 0.6 \\
\hline 4. & Aspirin-Gly-Phe-Met- $\mathrm{NH}_{2}(\mathrm{~V})$ & 2 & 1 & 2 & 2 & 1 & 1.6 \\
\hline 5. & Aspirin-Gly-Gly-Phe- $\mathrm{NH}_{2}(\mathrm{VI})$ & 2 & 3 & 2 & 2 & 3 & 2.4 \\
\hline 6. & Aspirin-Phe-Met- $\mathrm{NH}_{2}$ (III) & 4 & 4 & 5 & 4 & 4 & 4.2 \\
\hline 7. & Aspirin-Gly-Phe- $\mathrm{NH}_{2}$ (IV) & 5 & 3 & 4 & 5 & 3 & 4.0 \\
\hline 8. & Aspirin-Met- $\mathrm{NH}_{2}(\mathrm{I})$ & 8 & 7 & 9 & 8 & 7 & 7.8 \\
\hline 9. & Aspirin-Phe- $\mathrm{NH}_{2}$ (II) & 9 & 8 & 8 & 9 & 8 & 8.4 \\
\hline 10. & Aspirin-Gly-Gly-Phe-Leu- $\mathrm{NH}_{2}(\mathrm{C})$ & 1 & 2 & 3 & 1 & 2 & 1.8 \\
\hline 11. & Aspirin-Gly-Phe-Leu- $\mathrm{NH}_{2}(\mathrm{XI})$ & 3 & 2 & 1 & 3 & 2 & 2.2 \\
\hline 12. & Aspirin-Phe-Leu- $\mathrm{NH}_{2}$ (IX) & 5 & 4 & 5 & 5 & 4 & 1.6 \\
\hline 13. & Aspirin-Gly-Gly- $\mathrm{NH}_{2}(\mathrm{X})$ & 5 & 6 & 5 & 5 & 6 & 5.4 \\
\hline 14. & Aspirin-Leu- $\mathrm{NH}_{2}(\mathrm{VII})$ & 10 & 8 & 7 & 10 & 8 & 8.6 \\
\hline 15. & Aspirin-Gly- $\mathrm{NH}_{2}$ (VIII) & 7 & 8 & 9 & 7 & 8 & 7.8 \\
\hline
\end{tabular}

\subsection{The table reveals that:}

1. The first group of mouse administered with the control showed an average writhing of 66.4 .

2. The second group of mouse administered with the dispersion containing aspirin showed an average writhing of 13 .

3. The third group of mouse administered with the dispersion containing A showed an average writhing of 0.6 .

4. The fourth and fifth group of mouse administered with the dispersion containing $\mathrm{V}$ and VI showed an average writhing of 1.6 and 2.4 respectively. 
5. The sixth and seventh group of mouse administered with the dispersion containing III and IV showed an average writhing of 4.2 and 4.0 respectively.

6. The eighth and ninth group of mouse administered with the dispersion containing I and II showed an average writhing of 7.8 and 8.4 respectively.

7. The tenth group of mouse administered with the dispersion containing compound $\mathrm{C}$ showed an average writhing of 1.8 .

8. The eleventh group of mouse administered with the dispersion containing XI showed an average writhing of 2.2 respectively.

9. The twelth and thirteenth groups of mouse administered with the dispersion containing IX and X showed an average writhing of 4.6 and 5.4 respectively.

10. The fourteenth and fifteenth groups of mouse administered with the dispersion containing VII and VIII showed an average writhing of 8.6 and 7.8 respectively.

\section{Conclusion}

The present work was carried out with the aim of studying structure activity relationship in Aspririn- Gly-Gly-Phe- Met- $\mathrm{NH}_{2}$ (A). and Aspririn- Gly-Gly-Phe-Leu- $\mathrm{NH}_{2}$ (C). Six compounds incorporating aminoacid amide, dipeptide amide and tripeptide amide related to $\mathrm{A}$ and $\mathrm{C}$ were synthesized. Their analgestic activity were determined and compared with that of A and C.

From the mean writhing values, it is evident that the entire sequence of the tetrapeptideamide namely, Gly-Gly-Phe-Met- $\mathrm{NH}_{2}$ is essential for the observed analgesic activity of compound A. And, the entire sequence of the tetrapeptide amide namely, Gly-Gly-Phe-Leu- $\mathrm{NH}_{2}$ is essential for the observed analgesic activity of compound C. The decrease in analgesic activity of these compounds is in the order as follows,

Aspirin tripeptide amides > Aspirin dipeptide amides > aspirin aminoacid amides.

This shows that all the four amino acids are required for the observed activity of the parent compound (A) and(C) .Further research is warranted to investigate the pharmacokinetic parameters regarding the synthesized compounds.

\section{Acknowledgement:}

We thank the SIF, IISC, Bangalore for recording the NMR and IR Spectra. The author express thanks to the Secretary, the Principal and the management of Kongunadu Arts and Science College, Coimbatore, India for providing all the facilities to carry out this research work. 


\section{References}

Gilbert J. Hite, William O. Foye, Principles of Medicinal Chemistry, pp 261, 266, 298, 299, Lea \& Febiger, 1981.

Belluzzi, J.D., Grant, N., Garsky, V., Sarantakis, D., Wise, C.D., and Stein, L., Nature.1975, 260, 625 .

Birscher, H.H., Hill, R.C., Romer, D., Cardinaux, F., Closse, A., Houser, D and Pless, J., Nature, 1976,261, 423.

Chang, J.K. Fond, B.T.W., Pert, A., and Pert, C.B., Life science.,1976, 18, 1473 .

Jaquet, Y., Marks, N and Li, C.H., Ref 21., pp 411-414.

Bloom, F., Segal, D. Ling, N and Guillemin, R., Science,1976, 194, 630 .

Water field, A.A., Hughes, J and Koster litz, H.W., Nature, 1976,260, 624 .

Cowan, A., Doxey, J.C and Metcalf. G., Ref., 21, pp 95-102.

Morley, J.S., Ann. Rev. Pharmacol. Toxicol.1980, 20, 81.

10. Miller, R.J. Chang, K.J., Cuatrecass, P., Willkeinson, S., Lowe, L., Beddel, C and Follenfant, R., in centrally Acting peptides (Hughes, J., Ed.), pp 195-213, 1980,Macmillan, London.

11. Schwartz, J., Malfroy, B and Baume, S.D.L., Life Sci.,1980, 29, 1715.

12. Goernstein, C., and Snyder, S.H., Proc. R. Soc.1980, London, B 210, 123 .

13. Merrifield, R.B., J. Am. Chem. Soc, 1963,85, 2149-2154.

14. Arno Bundi, Christoph Grathwohl, journal of Magnetic resonance, 18, 1975, 191-198. 


HYGEIA
JOURNAL FOR DRUGS AND MEDICINES
October 2011-March 2012
A half yearly scientific international open access journal for drugs and medicines.

\title{
Evaluation of the Antibacterial activity of Cocculus hirsutus
}

\author{
Abiramasundari.P, Priya .V, Jeyanthi.G.P, and Gayathri Devi. S* \\ Department of Biochemistry, Biotechnology and Bioinformatics, Avinashilingam University for Women, Coimbatore-641 043. \\ Article history: Received: 02 April, 2011, revised: 10June2011, accepted: 2August 2011, Available online: 1 October 2011
}

\begin{abstract}
Herbal products prepared either from single or multiple botanical ingredients are usually complex and variable in nature. Undoubtedly, the plant kingdom still holds many species of plants containing substances of medicinal value that have yet to be discovered. For this reason, Cocculus hirsutus (L.) a medicinal plant belonging to family Menispermaceae, the perennial climber was selected for the present study. The study was formulated with the objective to assess the antibacterial activity of Cocculus hirsutus. The leaves stem and the root of Cocculus hirsutus were extracted with solvents namely petroleum ether, chloroform, benzene, acetone, methanol and water for the determination of antibacterial activity. The chance to find antibacterial activity was more apparent in methanol and acetone extracts than the other extracts. The benzene and methanol extracts of Cocculus hirsutus leaves have shown strong antibacterial activity against all the organisms tested. The zone of inhibition ranged from 8-16 mm. The petroleum ether, acetone and methanol extracts of Cocculus hirsutus stem have shown pronounced antibacterial activity against all the microorganisms tested. Zones diameter ranged from 9-21 mm. Based on the results, it can be concluded that the Cocculus hirsutus plant extracts have great potential as antimicrobial components against microorganisms and they can be used in the treatment of infectious diseases caused by resistant microorganisms.
\end{abstract}

Key words: Medicinal plants, Antibacterial activity, well diffusion method, Cocculus hirsutus, MIC, MBC.

\section{Introduction}

In recent years, multiple drug resistance in human pathogenic microorganisms has developed due to indiscriminate use of commercial antimicrobial drugs commonly used in the treatment of infectious diseases. The development of antibiotic resistance is multifactorial, including the specific nature of the relationship of bacteria to antibiotics, the usage of antibacterial agent, host characteristics and environmental factors. This situation has forced scientists to search for new antimicrobial substances from various sources as novel antimicrobial chemotherapeutic agents. The cost of production of synthetic drugs is also high and they produce adverse effects compared to plant derived drugs. Hence much attention has been paid recently to the biologically active compounds derived from plants used in herbal medicine $e^{1,2}$. For these reasons, medicinal plants are important substances for the study of their traditional uses through the verification of pharmacological effects and can be natural composite sources that act as new antiinfectious agents ${ }^{3}$.

*For Correspondence:

devigayathri75@yahoo.co.in

Contact: +919443935039

Abiramasundari P, Priya V, Jeyanthi GP GayathriDevi S, H.J.D.Med. Vol. 3 (2), October, 2011, pp26-31.

(C) 2010 Hygeia journal for drugs and medicines, all rights reserved. 2229 3590, 09756221 
Therefore in recent years, considerable attention has been directed towards the identification of plants with antimicrobial activity ${ }^{4}$.

The plant chosen for the present study is Cocculus hirsutus (L.) belonging to the family Menispermaceae which is a perennial climber mainly found in tropical and subtropical climatic condition ${ }^{5}$. The Cocculus hirsutus shows diuretic, laxative activity ${ }^{6}$, hypolipidemic activity ${ }^{7}$ and spermatogenic activity ${ }^{8}$. Traditionally the plant was patronized for its unique property of healing all type of cuts, wounds and boils in very less time and with less pain. It is also used in the treatment of gonorrhea, spermatorrhoea, urinary troubles, diarrhea and hyperglycemia ${ }^{9}$. Literature survey revealed that the leaves of the plant have been evaluated for anti hyperglycemic ${ }^{10}$ and diuretic effects. Folk medicine claims that it may be used in jaundice. The hepatoprotective effects of Cocculus hirsutus could be due to the presence of phytochemicals like $\beta$-sitosterol, trilobine, isotrilobine, syringaresional, protoquercitol, ginnol and glycosides ${ }^{11}$.

\section{Materials and Methods}

\section{Collection of the plant samples}

Cocculus hirsutus plants were procured from local markets in Coimbatore and duely authenticated by Dr. G.V.S. Murthy, Botanical Survey of India, Coimbatore. The leaves, stem and the root of the plant were separated out and they were washed, air dried in the shade at room temperature for five days. Dried leaves stem and roots of Cocculus hirsutus were powdered and stored until use.

\section{Preparation of the plant extracts}

Five gram powdered sample of leaves, stem and root of Cocculus hirsutus were sequentially extracted with solvents namely petroleum ether, benzene, chloroform, acetone, methanol and also with water by Soxhlet apparatus for $48 \mathrm{hrs}$. Then it was filtered through Whatman.No.1 filter paper and their crude extracts were evaporated in a water bath to give gummy solid residue. The residue was dissolved in dimethyl sulphoxide. These crude extracts were stored in refrigerator and screened for antibacterial activity. $0.001 \mathrm{~g}$ of extracts per $20 \mu 1$ were taken for the assay.

\section{Determination of the antibacterial activity}

\section{Selection of the microorganisms}

The bacterial strains used for this study include Bacillus subtilis, Staphylococcus aureus, Escherichia coli, Shigella dysentriae and Klebsiella pneumoniae. All the bacterial strains were grown and maintained in nutrient agar.

\section{Well Diffusion method}

The method of Rios et al ${ }^{12}$ was used in this study to determine the antibacterial activity of the various solvent extracts selected. The results are tabulated in Table: 1 . 


\section{Minimum Inhibitory Concentration (MIC)}

The MIC was defined as the lowest concentration of the compound to inhibit the growth of microorganisms. The minimum inhibitory concentration (MIC) values were determined by broth dilution assay. The cultures were prepared at $24 \mathrm{hr}$ broth cultures of B. subtilis, S. aureus, E. coli, S. dysentriae and K. pneumoniae respectively ${ }^{13}$.

\section{Minimum Bactericidal Concentration (MBC)}

MBC was determined for each set of wells. After incubation, the concentration at which no visible growth was noted as minimum bactericidal concentration ${ }^{14}$.

\section{Results and discussion}

There is an urgent need to control antimicrobial resistance by improved antibiotic usage and reduction of hospital cross infection. However, the development of new antibiotics should be continued as they are of prime importance to maintain the effectiveness of antimicrobial treatment. In developing countries, the WHO estimates that about three quarters of the population relies on plant based preparations used in their traditional medicinal system and as the basic need for human primary health care ${ }^{15}$.

Table 1: Antibacterial activity of Cocculus hirsutus leaf extract by well diffusion method (Diameter of zone in mm)

\begin{tabular}{cccccccc}
\hline Bacterial strains & & \multicolumn{3}{c}{ Solvent extracts } & \multicolumn{3}{c}{ Control } \\
& Petroleum ether & Chloroform & Benzene & Acetone & Methanol & Aqueous \\
\hline B. subtilis & $17.0 \pm 1.0$ & $13.0 \pm 1.2$ & $12.0 \pm 0.5$ & $8.0 \pm 1.0$ & $15.0 \pm 0.3$ & $7.0 \pm 0.5$ & 20 \\
E. coli & $16.0 \pm 0.6$ & $8.0 \pm 0.5$ & $15.0 \pm 0.0$ & $12.0 \pm 0.5$ & $14.0 \pm 0.5$ & $8.0 \pm 0.7$ & 20 \\
S. aureus & $9.0 \pm 0.0$ & $9.0 \pm 0.3$ & $15.0 \pm 0.7$ & $9.0 \pm 0.6$ & $12.0 \pm 0.0$ & $14.0 \pm 1.0$ & 24 \\
S. dysentriae & $9.0 \pm 0.5$ & $7.0 \pm 1.2$ & $16.0 \pm 0.0$ & $8.0 \pm 0.0$ & $15.0 \pm 0.5$ & $7.0 \pm 0.6$ & 21 \\
K. pneumoniae & $20.0 \pm 0.8$ & $7.0 \pm 0.5$ & $8.0 \pm 1.0$ & $9.0 \pm 1.0$ & $8.0 \pm 0.5$ & $7.0 \pm 0.5$ & 23 \\
\hline
\end{tabular}

Values are mean $\pm \mathrm{SD}$ in triplicates

Table 2: Antibacterial activity of Cocculus hirsutus stem extract by well diffusion method (diameter of zone in $\mathrm{mm}$ )

\begin{tabular}{|c|c|c|c|c|c|c|c|}
\hline \multirow[t]{2}{*}{ Bacterial strains } & \multicolumn{6}{|c|}{ Solvent extracts } & \multirow[t]{2}{*}{ Control } \\
\hline & Petroleum ether & Chloroform & Benzene & Acetone & Methanol & Aqueous & \\
\hline B. subtilis & $18.0 \pm 0.0$ & $20.0 \pm 0.7$ & $10.0 \pm 0.5$ & $17.0 \pm 0.7$ & $16.0 \pm 0.1$ & $9.0 \pm 0.0$ & 23.0 \\
\hline E. coli & $9.0 \pm 0.0$ & $7.0 \pm 0.0$ & $7.0 \pm 0.5$ & $13.0 \pm 0.7$ & $14.0 \pm 0.5$ & $9.0 \pm 0.0$ & 24.0 \\
\hline & $\begin{array}{l}20.0 \pm 0.5 \\
12.0 \pm 0.7\end{array}$ & $\begin{array}{c}12.0 \pm 0.7 \\
6.0 \pm 0.5\end{array}$ & $\begin{array}{l}8.0 \pm 0.0 \\
7.0 \pm 0.0\end{array}$ & $\begin{array}{c}9.0 \pm 1.0 \\
13.0 \pm 0.7\end{array}$ & $\begin{array}{l}21.0 \pm 1.0 \\
11.0 \pm 1.0\end{array}$ & $\begin{array}{l}7.0 \pm 1.0 \\
9.0 \pm 1.0\end{array}$ & $\begin{array}{l}20.0 \\
21.0\end{array}$ \\
\hline K. pneumoniae & $17.0 \pm 1.0$ & $19.0 \pm 0.0$ & $15.0 \pm 0.6$ & $13.0 \pm 0.5$ & $12.0 \pm 1.2$ & $10.0 \pm 0.7$ & 20.0 \\
\hline
\end{tabular}

Values are mean $\pm \mathrm{SD}$ in triplicates 
The various extracts such as petroleum ether, chloroform, benzene, acetone, methanol and aqueous extracts of Cocculus hirsutus leaves, stem and root were tested against Bacillus subtilis, Escherichia coli, Staphylococcus aureus, Shigella dysentriae and Klebiella pneumoniae for its antibacterial activity. The results are presented in Tables I-III.

In our study, all the extracts of the leaves of Cocculus hirsutus showed low activity against $S$. aureus except the benzene and aqueous extracts which showed pronounced inhibition $(15 \mathrm{~mm})$ and $(14 \mathrm{~mm})$ respectively against $S$. aureus.

Table 3: Antibacterial activity of Cocculus hirsutus root extract by Well diffusion method (diameter of zone in $\mathrm{mm}$ )

\begin{tabular}{|c|c|c|c|c|c|c|c|}
\hline \multirow{2}{*}{ Bacterial strains } & \multicolumn{6}{|c|}{ Solvent extracts } & \multirow{2}{*}{ Control } \\
\hline & Petroleum ether & Chloroform & Benzene & Acetone & Methanol & Aqueous & \\
\hline B. subtilis & $9.0 \pm 1.0$ & $7.0 \pm 0.5$ & $15.0 \pm 0.0$ & $14.0 \pm 0.6$ & $13.0 \pm 0.7$ & $7.0 \pm 0.5$ & 25.0 \\
\hline E. coli & $7.0 \pm 0.7$ & $12.0 \pm 0.5$ & $7.0 \pm 0.0$ & $15.0 \pm 0.5$ & $14.0 \pm 0.7$ & $10.0 \pm 0.5$ & 23.0 \\
\hline S. aureus & $13.0 \pm 1.0$ & $7.0 \pm 0.7$ & $8.0 \pm 0.5$ & $20.0 \pm 0.5$ & $18.0 \pm 0.0$ & $9.0 \pm 0.5$ & 24.0 \\
\hline S. dysentriae & $20.0 \pm 0.0$ & $8.0 \pm 0.0$ & $9.0 \pm 0.7$ & $11.0 \pm 0.5$ & $19.0 \pm 0.0$ & $8.0 \pm 0.7$ & 20.0 \\
\hline K. pneumoniae & $17.0 \pm 0.0$ & $14.0 \pm 0.0$ & $7.0 \pm 1.0$ & $8.0 \pm 0.5$ & $21.0 \pm 0.0$ & $9.0 \pm 0.7$ & 21.0 \\
\hline
\end{tabular}

Values are mean $\pm \mathrm{SD}$ in triplicates

Therefore, the potency of the benzene and aqueous extracts of the leaves against $S$. aureus largely could support their traditional use in the treatment of respiratory tract infections. The petroleum ether extracts of leaves of Cocculus hirsutus were found to be active against $K$. pneumoniae and B. subtilis and showed low acitivity against the rest of the tested organism. The methanol extracts of the leaves of Cocculus hirsutus were found to be active against all the tested organism.

The growth of $E$. coli was controlled by the methanol extract of Cocculus hirsutus stem which indicated that they could inhibit the bacterial activity, which can cause diarrhoea and dysentry. Similarly the presence of steroids and aminoacids in Cocculus hirsutus could correspond to its high antimicrobial activity exhibited against $E$. coli. The petroleum ether extract of the stem of Cocculus hirsutus was found to be highly active $(20 \mathrm{~mm})$ against $S$. aureus. Steroids and anthocyanins of Cocculus hirsutus stem could be responsible for their antimicrobial activity against $S$. aureus.

All the extracts of the root of Cocculus hirsutus exhibited pronounced activity against all the tested organism. 
However, petroleum ether and benzene extracts against E.coli and chloroform and benzene extracts against $S$. aureus showed low activity. These findings support the traditional knowledge of local users and it is a preliminary scientific validation for the use of this plant for antibacterial activity.

\section{Minimum Inhibitory Concentration (MIC)}

Minimum inhibitory concentration (MIC) was done for selected organisms using acetone and methanol extracts which gave maximum zone in well diffusion method. The results are presented in Tables IV-VI.

Table 4: Antibacterial activity of Cocculus hirsutus leaf extract against Bacillus subtilis and Staphylococcus aureus by (MIC)

\begin{tabular}{llllllllllll|l}
\hline Extracts & \multicolumn{1}{c}{ B. subtilis } & \multicolumn{1}{c}{ S. aureus } \\
\hline Con. $(\mathrm{mg} / 100 \mathrm{ml})$ & 0 & 4 & 2 & 1 & 0.5 & 0 & 4 & 2 & 1 & 0.5 \\
Acetone & - & + & + & - & - & - & + & + & - & - \\
Methanol & - & + & + & + & + & - & + & + & - & - \\
\hline$+:$ indicates positive activity & - : indicates negative activity & & &
\end{tabular}

Table 5: Antibacterial activity of Cocculus hirsutus stems extract against Bacillus subtilis and Staphylococcus aureus by (MIC)

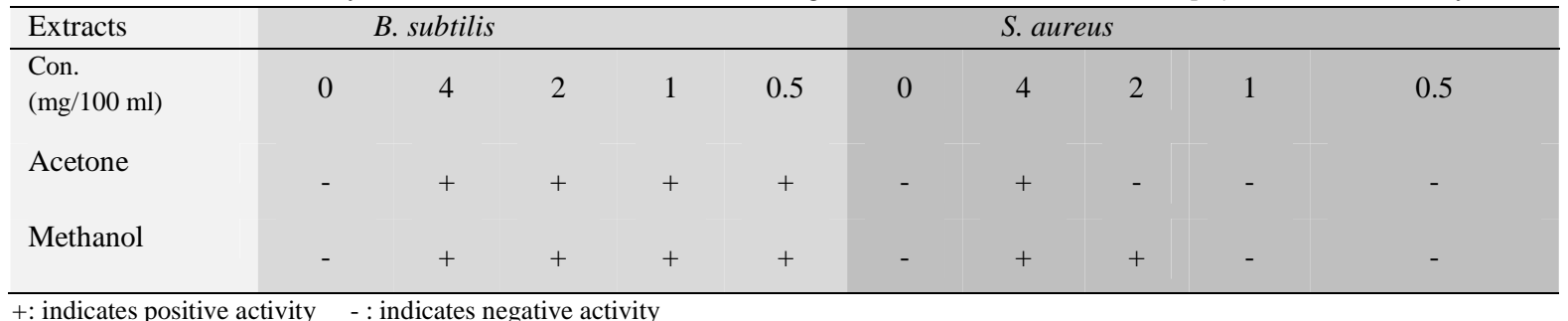

Table 6: Antibacterial activity of Cocculus hirsutus root extract against Bacillus subtilis and Staphylococcus aureus by (MIC)

\begin{tabular}{|c|c|c|c|c|c|c|c|c|c|c|}
\hline \multirow{2}{*}{$\begin{array}{l}\text { Extracts } \\
\text { Con. } \\
(\mathrm{mg} / 100 \mathrm{ml})\end{array}$} & \multicolumn{3}{|c|}{ B. subtilis } & \multicolumn{7}{|c|}{ S. aureus } \\
\hline & 0 & 4 & 2 & 1 & 0.5 & 0 & 4 & 2 & 1 & 0.5 \\
\hline Acetone & - & + & + & + & - & - & + & + & - & - \\
\hline Methanol & - & + & + & - & & - & + & - & - & - \\
\hline
\end{tabular}

Acetone and methanol extracts of leaves, stem and root of Cocculus hirsutus were inoculated against Bacillus subtilis and Staphylococcus aureus in the concentration of $4-0.5 \mathrm{mg} / 100 \mu \mathrm{l}$. The growth of Bacillus subtilis and Staphylococcus aureus were inhibited by Cocculus hirsutus. $4-1 \mathrm{mg} / 100 \mu \mathrm{l}$ of acetone and methanol extracts were found to be more effective against all the microorganisms analysed. 


\section{Minimum Bactericidal Concentration}

Based on the minimum inhibitory concentration results, the minimum bactericidal concentration (MBC) was performed against B. subtilis, E. coli, S. aureus, S. dysentriae and K. pneumoniae. There was no visible growth of any of these microorganisms.

Hence Cocculus hirsutus was found to have significant antibacterial activity against the microorganisms tested. The results of the present study support the traditional usage of Cocculus hirsutus and it can be recommended for usage as antimicrobial agents in new drugs for the therapy of infectious disease caused by pathogens.

\section{Conclusion}

Based on the results, it can be concluded that the Cocculus hirsutus plant extracts have great potential as antimicrobial components against microorganisms and they can be used in the treatment of infectious diseases caused by resistant microorganisms. Further work is needed to isolate the secondary metabolites from the extracts studied in order to test specific antibacterial activity and the underlying mechanisms.

\section{References}

1. Shai LJ, McGawa MA, Aderogbaa LK, Eloff JN, Four pentacyclic triterpenoids with antifungal and antibacterial activity from Curtisia dentata (Burm. f) leaves, J. Ethnopharmacol, 119, 2008, 238-244.

2. Firas A, Bayati A, Synergistic antibacterial activity between Thymus vulgaris and Pimpinella anisum essential oils and methanol extracts, J. Ethnopharmacol., 116, 2008, 403-406.

3. Ushimaru PI, silva M, Stasi L, Barbosa L, Junior AF, Antibacterial activity of medicinal plant extracts, Brazilian Journal of Microbiology, 38, 2007, 717719.

4. Patel VR, Patel PR, Kajal SS, Antioxidant activity of some selected medicinal plants in western region of India, Advances in Biological Research, 4(1), 2010, 23-26.

5. Panda BK, Mishra US, Antibacterial activity of the leaves of Cocculus hirsutus, Indian Drugs, 44, 2007, 108-110.

6. Ganapathy S, Dash GK, Suresh P, Diuretic, laxative and toxicity studies of Cocculus hirsutus aerial parts, Fitoterapia, 73, 2002, $28-31$.

7. Palsamy P, Malathy R, Evaluation of hypoglycemic and hypolipidemic activity of methanol extract of Cocculus hirsutus (L) diels leaves in sreptozotocininduced diabetic mellitus rats, $\quad$ Int. J. Biol. Chem., 1, 2007, 205-12.

8. Jayakar B, Sangameswaran B, Antidiabetic and spermatogenic activity of Cocculus hirsutus (L) Diels, African. J. Biotech., 6, 2007, 1212-16.

9. Kritikar KR, Basu BD, Indian Medicinal Plants, Sri Satguru Publication, New Delhi, $3^{\text {rd }}$ revised enlarged edition, 1, $2002,120$.

10. Badole S, Patel N, Badhankar S, Jain B, Bharadwaj S, Antihyperglycemic activity of aqueous extract of leaves of Cocculus hirsutus (L) Diels in alloxan induced diabetic mice, Ind. J. of Pharmacol., 38(1), 2006, 49-53.

11. Thakare SP, Jain HN, Patil SD, Upadhyay UM, Hepatoprotective effect of Cocculus hirsutus on bile duct ligation-induced liver fibrosis in Albino Wistar rats, Bangladesh. J. Pharmacol., 4, 2009, 126-130.

12. Rios JL, Recio MC, Villar A, Screening methods for natural products with antibacterial activity, A review of literature, J. Ethnopharmacol., 23, 1988, $127-149$.

13. Eloff JN, A sensitive and quick microplate method to determine the minimal inhibitory concentration of plant extracts for bacteria, Planta Med., 64 , 1998 , 711-713.

14. NCCLS, Methods for dilution antimicrobial susceptibility tests for bacteria that grow aerobically: Approved standard Fifth edition, 2000, NCCLS dominant M1745; NCCLS, Wayne, PA. USA.

15. Kaneria M, Baravalia Y, Vaghasiya Y, Chanda S, Determination of antibacterial and antioxidant potential of some medicinal plants from Saurashtra region, India, Indian. J. Pharm. Sci., 71(4), 2009, 406-412. 

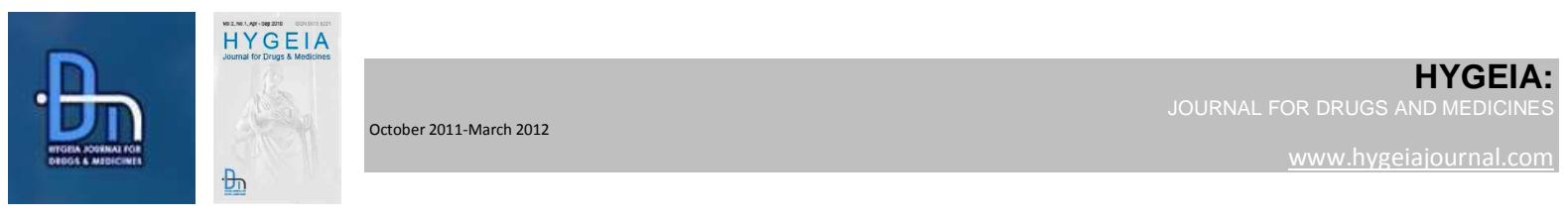

\title{
Anti hyperlipidemic activity of Spirulina platensis in Triton x-100 induced hyperlipidemic rats.
}

\author{
S.S.Sudha*, R.Karthic, Naveen, J.Rengaramanujam \\ P.G and Research Dept of Microbiology, Dr.N.G.P. Arts and Science College, Kalapatti, Coimbatore, Tamilnadu, India. \\ Article history: Received: 02 April, 2011, revised: 14July2011, accepted: 25July 2011, Available online: 1October 2011
}

\begin{abstract}
:
Hyperlipidemia is the greatest risk factor of coronary heart disease. The present study was designed to investigate the antihyperlipidemic activity of Spirulina platensis in Triton X-100 induced Hyperlipidemic rats. Spirulina platensis was administered at a dose of $0.5 \mathrm{gm} /$ day, (p.o) to Triton induced Hyperlipidemic rats. Fenofibrate is used as reference standard. The statistical analyses were carried out using one way ANOVA followed by Dunnet's multiple comparison test. S.platensis show a significant decrease in the levels of serum cholesterol, phospholipids, triglycerides, LDL, VLDL and significant increase in the level of serum HDL at the dose of $0.5 \mathrm{gm} /$ day (p.o) against Triton induced hyperlipidemic rats. Therefore it effectively suppressed the Triton induced hyperlipidemia in rats, suggesting the potential protective role in Coronary heart disease.
\end{abstract}

Key words: Spirulina platensis, Hyperlipidemia, Triglycerides, lipoprotein, Triton X-100.

\section{Introduction}

Hyperlipidemia has been ranked as one of the greatest risk factors contributing to the prevalence and severity of coronary heart diseases (16). Coronary heart disease, stroke, atherosclerosis and hyperlipidemia are the primary cause of death (5). Hyperlipidemia is characterized by elevated serum total cholesterol, low density lipoprotein, very low density lipoprotein and decreased high density lipoprotein levels. Hyperlipidemia associated lipid disorders are considered to cause atherosclerotic cardiovascular disease (17). Among these hypercholesterolemia and hypertriglyceridemia are closely related to ischemic heart disease (1). The main aim of treatment in patients with hyperlipidemia is to reduce the risk of developing ischemic heart disease or the occurance of further cardiovascular disease or cerebrovascular disease (4). Currently available drugs have been associated with number of side effects (15). The consumption of synthetic drugs leads to hyperuricemic, diarrhoea, nausea, myositis, gastric irritation, flushing, dry skin and abnormal liver function (2).

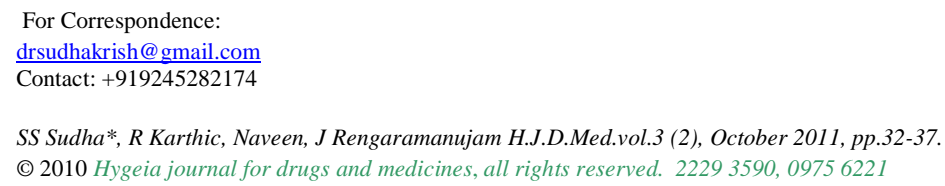


Certainly, a food, a nutritional supplement or a drug that has documented anti-viral activity as well as an ability to positively affect the immune response would be of considerable clinical interest.

Based on the existing research, Spirulina shows great potential in both of these related areas of disease resistance.Unique nutrients found within Spirulina once again play an important role in Spirulina's function as an antiviral (8). Spirulina(Arthrospira) may have a beneficial effect in the prevention of cardiovascular diseases. Decreases in blood pressure and plasma lipid concentrations, especially triacylglycerols and low density lipoprotein-cholesterol have been demonstrated as a result of oral consumption of Spirulina. It has also been shown to indirectly modify the total cholesterol and high density lipoproteincholesterol values (11). A water extract from Spirulina may inhibit the intestinal absorption of dietary fat by inhibiting pancreatic lipase activity (6). As the antihyperlipidemic activity of Spirulina platensis had not been elucidated in an exclusive Triton induced hyperlipidemic animal model, the present study has been designed to evaluate the lipid controlling activity of S. platensis in Triton induced hyperlipidemia in Wistar albino rats.

\section{Materials and Methods}

Spirulina, a fine dark blue-green spray-dried powder was obtained from the OFERR Nallayan Research Centre, Chennai, Tamil Nadu, India). The composition of the Spirulina used in our experiments was made up of proteins $(65.38 \%)$, crude phycocyanin $(15.37 \%)$, minerals $(7.95 \%)$, total carotenoids $(4.3$ $\mathrm{mg} / \mathrm{g}), \beta$-carotene $(1.67 \mathrm{mg} / \mathrm{g})$ and total pheophorbide $(0.02 \%)$.

\subsection{Chemicals}

Triton X-100(a non-ionic detergent, iso octyl polyoxy ethylene phenol, formaldehyde polymer) was obtained from Technicho lab chemicals, Coimbatore. Fenofibrate was obtained from Moral labs, Chennai. All other chemicals were of analytical grade and obtained locally.

\subsection{Preliminary Phytochemical analysis}

The Ethanolic extract of Spirulina platensis was subjected to preliminary phytochemical screening (10 \& 7).

\subsection{Experimental Animals}

Wistar albino adult male rats weighing 200-250g were obtained from the animal house KMCH College of Pharmacy, Coimbatore, India. The animal were grouped and housed in polyacrylic cages $(38 \times 23 \times 10$ $\mathrm{cm}$ ) with not more than five animals per cage and maintained under standard laboratory under standard laboratory conditions (temperature $25+2 \mathrm{oC}$ ) with dark and light cycle (14/10 hour). They were allowed free access to standard dry pellet diet (Hindustan Lever, Kolkata, India) and water ad libitum. The mice were acclimatized to laboratory condition for 10 days before commencement of experiment. 
The experimental protocol was approved by Institutional Animal Ethical Committee (IAEC) constituted under CPCSEA.

\section{Acute toxicity studies}

Albino mice weighing 22-25 g selected by random sampling technique were used in the study. Acute oral toxicity was performed as per OECD- 423 guidelines (acute class method) (3) . The animals were fasted overnight, provided only water after which extract was administered to the groups orally at the dose level of $5 \mathrm{mg} / \mathrm{kg}$ body weight by gastric intubation and the groups were observed for 14 days. If mortality was observed in 2 or 3 animals among 6 animals then the dose administered was assigned as a toxic dose. If mortality was observed in one animal, then the same dose was repeated again to confirm the toxic dose.

If mortality was not observed, the procedure was repeated for further higher doses such as 50, 300 and $2,000 \mathrm{mg} / \mathrm{kg}$ body weight. The animals were observed for toxic symptoms such as behavioral changes, locomotion, convulsions and mortality for 72 hours.

\section{Antihyperlipidemic studies}

\subsection{Induction of Hyperlipidemia}

Hyperlipidemia was induced in Wistar albino rats by single intraperitoneal injection of freshly prepared solution of Triton-X-100 (100 mg/kg) in physiological saline solution after overnight fasting for $18 \mathrm{~h}(\mathbf{9})$.The animals were divided into four groups of five rats each. The first group was given standard pellet diet, water and orally administered with 5\% CMC. The second group was given a single dose of triton administered at a dose of $100 \mathrm{mg} / \mathrm{kg}$, i.p. After 72 hours of triton injection, this group received a daily dose of 5\% CMC (p.o) for 7 days. The third group was administered a daily dose of Spirulina platensis $0.5 \mathrm{~g} /$ day suspended in 5\%CMC, p.o., for 7 days, after inducing hyperlipidemia. Fourth group was administered with the standard Fenofibrate $65 \mathrm{mg} / \mathrm{kg}$, p.o. for 7 days (13).

\subsection{Collection of blood}

On the 8thday, blood was collected by retero orbital sinus puncture, under mild ether anaesthesia. The collected samples were centrifuged for 10 minutes. Then serum samples were collected and used for various biochemical experiments. The animals were then sacrificed and the liver collected (19).

\subsection{Liver lipid extraction}

The liver was homogenized in cold $0.15 \mathrm{M} \mathrm{KCl}$ and extracted with $\mathrm{CHCl} 3 \mathrm{CH} 3 \mathrm{OH}(2 \% \mathrm{v} / \mathrm{v})$. This lipid extract was used for the estimation of lipid parameters (14). 


\section{4. Biochemical analysis}

The serum and liver extract were assayed for total cholesterol, triglycerides, phospholipids, high-density lipoprotein (HDL), low-density lipoprotein (LDL), very low-density lipoprotein (VLDL) using standard protocol methods (18).

\section{Statistical analysis}

The results were expressed as mean + S.E.M. Statistical analysis was carried out by using ANOVA followed by Dunnet's multiple comparison tests using Graph pad PRISM software version. P values < 0.05 were considered as statistically significant.

\section{Result and Discussion}

The cardiovascular benefits of Spirulina use are described in many papers. A review published in 2009 noted several reports suggesting that Spirulina (Arthrospira) may have a beneficial effect in the prevention of cardiovascular diseases. Decreases in blood pressure and plasma lipid concentrations, especially triacylglycerols and low density lipoprotein-cholesterol have been demonstrated as a result of oral consumption of Spirulina.

Spirulina has also been shown to indirectly modify the total cholesterol and high density lipoprotein cholesterol values (12). The ethanolic extract of S.platensis was found to be non-toxic up to the dose of $2 \mathrm{~g} / \mathrm{kg}$ and did not cause any death of the tested animals.

The Phytochemical tests with the ethanol extract of S.platensis indicated the presence of carbohydrates, glycosides, terpenes, saponins, proteins and amino acids. Hyperlipidemia is associated with heart disease, which is the leading cause of death in the world. The lowering of the levels of harmful lipids to satisfactory values have been confirmed by several experimental animal and interventional studies indicating lowered morbidity and mortality in coronary heart diseases. The results are discussed under the lipid profile in serum and the lipid profile in liver. Lipid profile in serum and liver indicates that increased phospholipids (PL), triglyceride (TG) and cholesterol levels were significantly reduced by treatment of $0.5 \mathrm{~g} /$ day Spirulina platensis. LDL and VLDL levels were significantly increased in tritoninjected animals to control rats. The results are shown in Tables 1and 2. The S.platensis markedly lowers the levels of serum cholesterol and VLDL. The decrease in cholesterol may indicate increased oxidation of mobilized fatty acids of inhibition or lipolysis. The present investigation shows that all triton induced rats displayed hyperlipidemia as shown by their elevated levels of serum and liver cholesterol, triglyceride, PL, VLDL, LDL and the reduction in the HDL level. It can be concluded that $0.5 \mathrm{~g} /$ day of S.platensis treatment was effective in reduction of cholesterol, PL, TG, VLDL, LDL and HDL in a dose dependant manner. 


\section{Acknowledgement}

The first, second and third authors are grateful to University Grant Commission (UGC) for the financial support given to the present study under the Major Research Project programme entitled "Investigation on crude and bioactive compounds from marine micro algae for preventing Coronary Heart Disease" (Sanction No. F. 38-56/2009 (SR) dated on 19.12.2009). The authors are thankful to the management of Dr.N.G.P. Arts and Science College for their encouragement and support.

Table 1: Effect of Spirulina platensis on HDL, LDL, VLDL in Serum of Control and Experimental Rats

\begin{tabular}{llll}
\hline Groups & \multicolumn{3}{c}{ Parameters } \\
\hline \multicolumn{1}{c}{ HDL } & \multicolumn{1}{c}{ LDL } & VLDL \\
\hline Group-I control & $51 \pm 2.21$ & $162.3 \pm 2.32$ & $30.6 \pm 1.16$ \\
Group-II Triton treated & $38.1 \pm 3.2 *$ & $198.21 \pm 3.21^{*}$ & $48.4 \pm 2.32 * *$ \\
Group-III Triton + Spirulina $(0.5 \mathrm{~g} /$ day $)$ & $47.3 \pm 1.21^{* *}$ & $170.31 \pm 5.21 * *$ & $34.2 \pm 2.51 * *$ \\
Group-IV Triton + Fenofibrate & $49.1 \pm 2.2 * *$ & $167.3 \pm 4.31 * *$ & $32.4 \pm 1.61 * *$ \\
\hline Values are in mean + SE; Number of animals in each group $=5 ; * \mathrm{p}<0.05$ Vs Group I; $* * \mathrm{p}<0.05$ Vs Group II
\end{tabular}

Table 2: Effect of Spirulina platensis on Cholesterol, Triglycerides, Phospholipids in Serum of Control and Experimental Rats

\begin{tabular}{lll}
\hline Groups & \multicolumn{2}{c}{ Parameters } \\
\hline & \multicolumn{1}{c}{ Cholesterol } & Triglyceride \\
\hline Group-I control & $248.5 \pm 2.12$ & $151 \pm 1.4$ \\
Group-II Triton treated & $312.2 \pm 1.48^{*}$ & $194.2 \pm 2.21^{*}$ \\
Group-III Triton + Spirulina $(0.5 \mathrm{~g})$ & $261.4 \pm 3.23^{* *}$ & $159.3 \pm 1.31^{* *}$ \\
Group-IV Triton + Fenofibrate & $254.3 \pm 2.21^{* *}$ & $154.3 \pm 2.12^{* *}$ \\
\hline
\end{tabular}

Values are in mean $\pm \mathrm{SD}$; Number of animals in each group $=5 ; * \mathrm{p}<0.05$ Vs Group I; ** $\mathrm{p}<0.05$ Vs Group II

\section{References:}

1. A.Y.Kaesancini and R.M.Krauss. Cardiovascular disease and hyperlipidemia. Cur. Opinion in lipidology. 5:1994, pp: 249-251.

2. Brown SL. Lowered serum cholesterol and low mood: British Journal of medicine. 313:1996, pp: 637-638.

3. Ecobichon D J, The Basis of Toxicology Testing, $3^{\text {rd }}$ Edition New York, CRC Press, 1997; pp: 43.

4. G.Davey smith and J.Pekkanen. Should there be a moratorium on the use of cholesterol lowering drugs? Br. Med J. 304:1992,pp: 431-440.

5. G.Davey Smith. Cholesterol lowering and mortality: the importance of considering initial level of risk. Int. Med. J. 306:1993, pp: 1367-1373.

6. Han LK, Li DX, Xiang L, Gong XJ, Kondo Y, Suzuki I, Okuda H(2006) Isolation of pancreatic lipase activity-inhibitory component of Spirulina platensis and it reduces postprandial triacyglycerolemia Yakugaku Zasshi J Pharmaceut Soc Japan 126(1)2006,pp: 4349.

7. Harbone J B , Phyto chemical methods, a guide to modern techniques of plant analysis, Chapman and Hall, London 1973;pp.1.

8. Hayashi T, Hayashi K, Maeda M, Kojima I. Calcium Spirulan, an inhibitor of enveloped virus replication, from a blue green alga Spirulina platensis J Nat prod 59(1):1996,pp: 83-87. 
9. Hicham hurnafi, Nour el Houda Bouanani, Mohammed Aziz, Hana Serghini Caid, Noreddine Ghalim and Souliman Amrani. The hypolipidaemic Triton WR-1339 induced hyperlipidaemic rats: A comparision with fenofibrate. J.of.Ethnopharmacol. 109:2007, pp: 156- 160 .

10. Jain, S.C.Isolation of flavonoids from soapnut, Sapindus emarginatus Vahl. Indian J Pharm Nov/Dec 1976; 38 (6) pp. 141.

11. Juarez-Oropeza MA, Mascher D, Torres-Duran PV, Farias JM, Paredes-Carbajal MC Effects of Spirulina on vascular reactivity J Med Food 12(1)2009, pp: 15-20.

12. Juarez-Oropeza MA, Mascher D, Torres-Duran PV, Farias JM, Paredes-Carbajal MC (2009) Effects of Spirulina on vascular reactivity $J$ Med Food 12(1) 2009, pp: 15-20.

13. K.Muramatsu, M.Fukuyo and Y.Hara. Effect of green Tea catechins on plasma cholesterol level in cholesterol feed rats. J. Nutr. Sci. Vitaminol. 56:1986, pp: 509-520.

14. Moss JN, Dajani EZ. Antihyperlipidemic agents. Im: Turner RA, Hebben PA. Screening methods in Pharmocology. Vol 2. New York: Academic Press; 1971.pp: 121-43.

15. S.L.Brown. Lowered serum cholesterol and low mood. Br. Med. J.313:1996,pp: 637-638.

16. S.M.Grundy. Cholesterol and coronary heart disease: a new era. J.Am. Med. Assoc. 256: 1986, pp: 2849-2858.

17. Saravanan, N.Rajendra Prasad and K.V. Pugalandi. Effect of Piper betle leaf extract on alcoholic toxicity in the rat brain.J.Med.Food. 6:2003, pp: 261-265.

18. Vogel G, Vogel WH. Influence of lipid metabolism. In: Drug Discovery and Evaluation Pharmacological Assay. Springer-Verly: Berloin; 1997. pp: 604-8.

19. Z.Y.Ding, Y.Chen, M.Zhou and Y.Z. Fang. Inhibitory effect of green tea polyphenol and murin on the oxidative modification of low-density lipoprotein. Clin. J. Pharmacol. Toxicol. 6:1992, pp: 263- 266. 


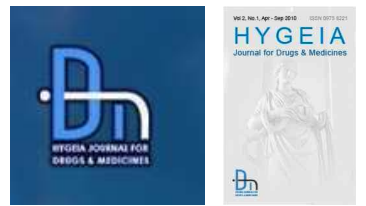

HYGEIA:

\title{
Synthesis and Ulcer reducing activity studies of some Peptide derivatives of Aspirin
}

\author{
M. Sekar ${ }^{*}$ and J. Balamani ${ }^{2}$ \\ 1. Post Graduate and Research Department of Chemistry, Kongunadu Arts and Science College, Coimbatore-641 029, India. \\ 2*. Post Graduate and Research Department of Chemistry, Sri Ramakrishna Mission Vidyalaya College of Arts and Science, Coimbatore-641 020, India. \\ Article history: Received: 15 December, 2010, revised: 24 May, 2011, accepted: 28 June, 2011, Available online: 1 October 2011.
}

\begin{abstract}
:
Tetrapeptide derivatives of Aspirin (1 to 4) were synthesized by the following methods. Aspirin was prepared by acetylation of salicylic acid using $\mathrm{Ac}_{2} \mathrm{O} / \mathrm{AcOH}$. Aspirin was coupled with aminoacid amide and dipeptide amide using its p-nitro phenyl $\left(N_{P}\right)$ ester. The ester (Aspirin - ON $N_{P}$ ) was prepared by treating p-nitro phenol and DCC in EtOAc and was precipitated by using EtOH. The synthesis of dipeptide amides were carried out in solution by stepwise elongation of the peptide chain from the C-terminal aminoacid by coupling one aminoacid at a time using DCC/HOBt method. Boc-group was used from $N^{\alpha}$ protection of all amino acids. The Boc-group cleavage was carried out using 50\% TFA / $\mathrm{CH}_{2} \mathrm{Cl}_{2}$. The amidation of C-terminal aminoacid was carried out by treating the corresponding Boc - aminoacid - ONp esters with dry $\mathrm{NH}_{3}$ in presence of DCC and HOBt. Their gastric ulcer inducing property was studied by histopathological method.
\end{abstract}

Keywords: Aspirin - ONp, Boc $-\mathrm{N}_{3}$ (t-butyl azido formate), HOBt (1-Hydroxy benzotriazole), DCC (N, $\mathrm{N}^{1}-\mathrm{Dicyclo}$ hexyl carbodiimide) and DCU (N, $\mathrm{N}^{1}-$ Dicyclohexyl urea).

\section{Introduction}

Salicylic acid was found to possess analgesic activity ${ }^{1}$ and it was used for the treatment of integumental pain, headache and reduce fever. Nevertheless, it was not used medicinally due to its bad effect of producing gastric disturbances. But, their derivatives are found to be useful. Aspirin is used for musculo skeletal disorders. In a sufficiently large dose, aspirin acts as an anti rheumatic and antiplatelet agent. In a single dose, aspirin produce only analgesic action. Use of analgesics requires an understanding of the biochemical and physiological mechanism of analgesics ${ }^{2}$.To improve the solubility and to reduce the side effects of Aspirin $^{3}$ various peptide derivatives of aspirin were synthesized by attaching the peptide fragments to the carboxyl group of aspirin ${ }^{5,6,7,8,9}$

Aspirin prepared from Salicylic acid could be obtained in highly pure form after recrystallisation twice or thrice in hot water. The glycine amino acid sample which usually contains small quantities of glycylglycine was removed after $\mathrm{N}^{\alpha}$-protection using Boc group by using column packed with silica gel and solvent system A. [Chloroform : Methanol : Acetic Acid (40:2:1)]. 
Aspirin - $\mathrm{ONp}^{10}$ and Boc-aminoacids ${ }^{11}$ were prepared using the reported procedure. Boc-aminoacid$\mathrm{NH}_{2}$ was prepared using Boc-amino acid / dry $\mathrm{NH}_{3} / \mathrm{DCC} / \mathrm{HOBt}$ and was obtained in about $85 \%$ yield. The structure of Aspirin, Aspirin-ONp, Boc-Leu, Boc-Met, Boc-Leu-NH $\mathrm{N}_{2}$, Boc-Met $\mathrm{NH}_{2}$, BocPhe, Boc-Phe- $\mathrm{NH}_{2}$ were confirmed by IR data.

The tetrapeptide derivatives of aspirin ,Asp - Gly - Gly - Phe - Met - $\mathrm{NH}_{2}$ (1), Asp - Gly - Gly Phe - Met - OMe (2)

Asp - Gly - Gly - Phe - Leu - $\mathrm{NH}_{2}$ ( 3), Asp - Gly - Gly - Phe - Leu - OMe ( 4) were synthesized by attaching the peptide fragments to the carboxyl group of aspirin by DCC / $\mathrm{HOBt}^{12}$ method and were homogenous. The structure of Asp - Phe - Leu - $\mathrm{NH}_{2}$, Asp - Gly - Phe - Leu - $\mathrm{NH}_{2}$, Asp - Gly - Gly - Phe - Leu - $\mathrm{NH}_{2}$, Asp - Phe - Met - $\mathrm{NH}_{2}$, Asp - Gly - Phe - Met $\mathrm{NH}_{2}$, Asp - Gly - Gly Phe - Met $-\mathrm{NH}_{2}$ were confirmed by NMR spectral data. Their analgesic potency and their ulcer inducing property were determined.

In IR spectrum, no broad band around $3345 \mathrm{~cm}^{-1}$ shows the absence of $\mathrm{O}-\mathrm{H}$ group in Boc-aminoacid. Two sharpbands at $3400 \mathrm{~cm}^{-1}$ and $3193 \mathrm{~cm}^{-1}$ observed may correspond to the asymmetric and symmetric NH stretching frequencies of the primary amide. The band at $1720 \mathrm{~cm}^{-1}$ observed may be due to carbonyl group. The sharp band around $3348 \mathrm{~cm}^{-1}$ may be due to the $\mathrm{NH}$ stretching of the secondary amide. Further proof from the NMR spectrum of the peaks at $\delta 2.27, \delta 8.3, \delta 7.95$ shows the presence of $-\mathrm{COCH}_{3}$, - $\mathrm{NH}-$, and $-\mathrm{NH}_{2}$ groups respectively. These details confirms the following structure for the products $(1,2,3$ and 4$)$

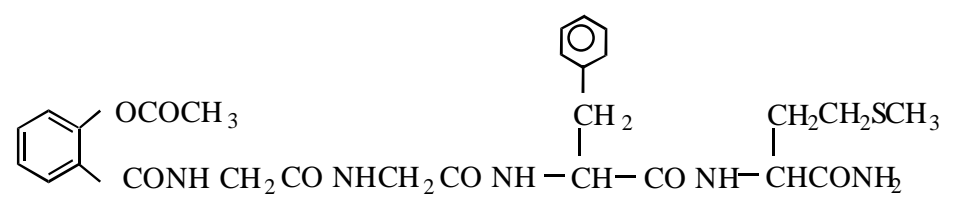

Glycyl - Glycyl - Phenylalanyl - Methionine amide of Aspirin (1)

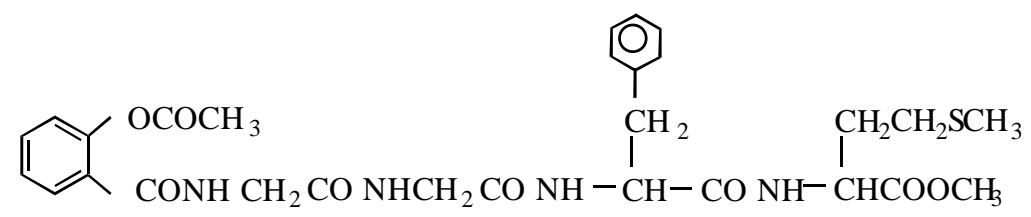

Glycyl - Glycyl - Phenylalanyl - Methionine ester of Aspirin (2)

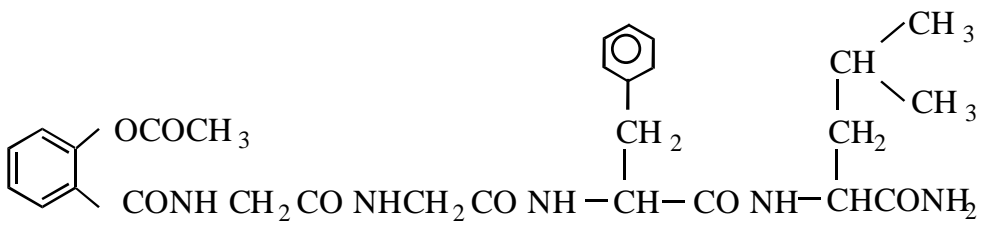

Glycyl - Glycyl - Phenylalanyl - Leucine amide of Aspirin (3) 


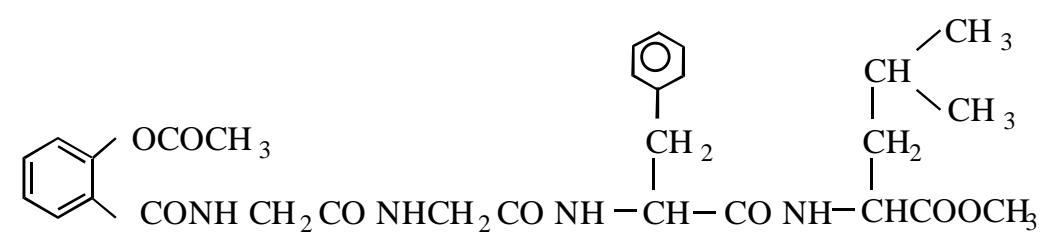

Glycyl - Glycyl - Phenylalanyl - Leucine ester of Aspirin (4)

\section{Experimental}

\subsection{Synthesis of tetrapeptide amide of aspirin:-}

Synthesis of Asp-Gly-Gly-Phe-Met- $\mathrm{NH}_{2}$ (1)

The tetrapeptide derivative of Aspirin , Aspirin -Glycine-Glycine-Phenylalanine -Methionine amide (1) is prepared by the following methods .Boc -Met (1a) $(2.5 \mathrm{~g}, 10 \mathrm{~m}$.moles ) and $\mathrm{HOBt}$ (1.5g,11m.moles)in $\mathrm{CH}_{2} \mathrm{Cl}_{2}(40 \mathrm{ml})$ and DMF (10ml), DCC $(2.1 \mathrm{~g}, 10.5 \mathrm{mmoles})$ in $\mathrm{CH}_{2} \mathrm{Cl}_{2}(20 \mathrm{ml})$ were added and the mixture was stirred for thirty minutes. Then dry $\mathrm{NH}_{3}$ was passed through the solution and stirred for 4-5 hrs till saturation. The Boc-Met $\mathrm{NH}_{2}$ (2a) obtained was deprotected by treating with a $1: 1$ mixture of TFA $/ \mathrm{CH}_{2} \mathrm{Cl}_{2}$ for 30 minutes. Then the residue was treated with $5 \mathrm{M}$ $\mathrm{HCl} / \mathrm{THF}$ for 30 minutes to get $\mathrm{HCl}$ Met $\mathrm{NH}_{2}$. This $\mathrm{HCl}$. Met $\mathrm{NH}_{2}$ was dissolved in dry DMF $(12 \mathrm{ml})$ and neutralized with $\mathrm{Et}_{3} \mathrm{~N}$. To this was added a solution of Boc-Phe $(2.1 \mathrm{~g}, 8 \mathrm{mmoles})$ and $\mathrm{HOBt}(1.1 \mathrm{~g}$, 8 mmoles) in $\mathrm{CH}_{2} \mathrm{Cl}_{2}(15 \mathrm{ml})$. The mixture was cooled to $0^{\circ} \mathrm{C}$ and to this a cold solution of DCC in $\mathrm{CH}_{2} \mathrm{Cl}_{2}(15 \mathrm{ml})$ was added drop wise under stirring to get Boc-Phe-Met- $\mathrm{NH}_{2}(\mathbf{3 a})$.

The Boc-Phe-Met- $\mathrm{NH}_{2}$ was deprotected by the above procedure to get $\mathrm{HCl}$.Phe-Met- $\mathrm{NH}_{2}$. This was dissolved in dry $\operatorname{DMF}(8 \mathrm{ml})$ and neutralized with $\mathrm{Et}_{3} \mathrm{~N}$ and added a solution of Boc-Gly $(1 \mathrm{~g}, 5.5$ mmoles) and $\mathrm{HOBt}(0.8 \mathrm{~g}, 5.5 \mathrm{mmoles})$ in $\mathrm{CH}_{2} \mathrm{Cl}_{2}(10 \mathrm{ml})$. The mixture was cooled to $0^{\circ} \mathrm{C}$ and to this a cold solution of DCC $(1.1 \mathrm{~g}, 5.5$ mmoles $)$ in $\mathrm{CH}_{2} \mathrm{Cl}_{2}$ was added dropwise under stirring to get BocGly-Phe-Met- $\mathrm{NH}_{2}(\mathbf{4 a})$. Then this was deprotected and another aminoacid Glycine was introduced to get Boc-Gly-Gly-Phe-Met-NH $\mathrm{N}_{2}$ (5a).

The compound (5a) was deprotected by treating with a 1:1 mixture of TFA/ $\mathrm{CH}_{2} \mathrm{Cl}_{2}$ (5ml) for 30 minutes at room temperature. The residue was treated with $5 \mathrm{M} \mathrm{HCl} / \mathrm{THF}$ for 30 minutes to get HCl.Gly-Gly-Phe-Met- $\mathrm{NH}_{2}$. This was dissolved in dry DMF and neutralized with $\mathrm{Et}_{3} \mathrm{~N}$.To this was added a solution of aspirin-ONp (0.8g, 2.5 mmoles) and $\mathrm{HOBt}(0.3 \mathrm{~g}, 2.5$ mmoles $)$ in $\mathrm{CH}_{2} \mathrm{Cl}_{2}(5 \mathrm{ml})$ and stirred for $24 \mathrm{~h}$ at room temperature to get Asp-Gly-Gly-Phe- Met- $\mathrm{NH}_{2}(\mathbf{1})$ and was obtained in $73 \%$ yield(scheme 1 ,table 1 ).

The other tetrapeptide amide Asp-Gly-Gly-Phe-Leu- $\mathrm{NH}_{2}$ (3) was also prepared by the same methodology and was obtained in $76 \%$ yield (scheme I, table I). 


\subsection{Synthesis of tetrapeptide ester of aspirin}

Synthesis of Asp-Gly-Gly-Phe-Met-OMe(2)

Super dry methanol $(10 \mathrm{ml})$ was cooled in an ice salt bath to $-5^{\circ} \mathrm{C}$ and with stirring thionyl chloride (2.6ml) was added during 20 minutes. Methionine (6a) (1.4 g, 10 mmoles ) was then added in small portions during 20 minutes and stirred vigorously for $2 \mathrm{~h}$ below $0{ }^{\circ} \mathrm{C}$ and slowly allowed to attain room temperature to get Met-OMe.HCl (7a).A stirred solution of 7a (3.6g, 18mmoles) in dry DMF (30ml) was neutralized with $\mathrm{Et}_{3} \mathrm{~N}$. To this was added a solution of Boc-Phe $(2.7 \mathrm{~g}, 10 \mathrm{mmoles})$ and $\mathrm{HOBt}$ (1.4 g, 10 mmoles) in $\mathrm{CH}_{2} \mathrm{Cl}_{2}(15 \mathrm{ml})$. The mixture was cooled to $0^{\circ} \mathrm{C}$ and to this a cold solution of DCC (2.1g, 10 mmoles) in $\mathrm{CH}_{2} \mathrm{Cl}_{2}(15 \mathrm{ml})$ was added dropwise under stirring. The reaction mixture was then stirred for about $1 \mathrm{~h}$ at $0^{\circ} \mathrm{C}$ and for about $24 \mathrm{~h}$ at room temperature to get Boc- Phe- MetOMe (8a).

The compound (8a) was deprotected by the usual procedure and the HCl- Phe- Met-OMe was dissolved in dry DMF $(12 \mathrm{ml})$ and neutralized with $\mathrm{Et}_{3} \mathrm{~N}$. To this was added a solution of Boc-Gly (1.4 g, 8 mmoles) and HOBt (1.1 g, 8 mmoles) in $\mathrm{CH}_{2} \mathrm{Cl}_{2}(15 \mathrm{ml})$. The mixture was cooled $0^{\circ} \mathrm{C}$ and to this a cold solution of DCC (1.6 g, 8mmoles) in $\mathrm{CH}_{2} \mathrm{Cl}_{2}(15 \mathrm{ml})$ was added dropwise under stirring . The reaction mixture was then stirred about $1 \mathrm{~h}$ at $0^{\circ} \mathrm{C}$ and for about $15 \mathrm{~h}$ at room temperature to get Boc- Gly-Phe- Met-OMe (10a). The compound (10a) was deprotected and the hydrochloride salt was dissolved in dry DMF $(8 \mathrm{ml})$ and neutralized with $\mathrm{Et}_{3} \mathrm{~N}$. To this was added a solution of Boc-Gly (1g,5.5m.moles) and $\mathrm{HOBt}(0.8 \mathrm{~g}, 5.5$ mmoles $)$ in $\mathrm{CH}_{2} \mathrm{Cl}_{2}(10 \mathrm{ml})$.

The mixture was cooled to $0^{\circ} \mathrm{C}$ and to this a cold solution of $\mathrm{DCC}(1.1 \mathrm{~g}, 5.5 \mathrm{mmoles})$ in $\mathrm{CH}_{2} \mathrm{Cl}_{2}$ $(10 \mathrm{ml})$ was added dropwise under stirring. The reaction mixture was then stirred for about $1 \mathrm{~h}$ at $0^{\circ} \mathrm{C}$ and for about $15 \mathrm{~h}$ at room temperature to get Boc-Gly- Gly- Phe- Met-OMe(12a).The compound (12a) was deprotected and the $\mathrm{HCl}$. Gly-Gly-Phe-Met-OMe was dissolved in dry DMF (5ml) and neutralized with $\mathrm{Et}_{3} \mathrm{~N}$. To this was added a solution of Aspirin - ONp (1.0 g, $\left.3 \mathrm{mmoles}\right)$ in $\mathrm{CH}_{2} \mathrm{Cl}_{2}$ $(5 \mathrm{ml})$. The reaction mixture was stirred for $24 \mathrm{~h}$ at room temperature to get Aspirin-Gly-Gly-Phe-MetMe (2) and was obtained in $75 \%$ yield(scheme 2,table 1). The same procedure is adopted to get Aspirin-Gly-Gly-Phe-Leu-OMe (4) and was obtained in $75 \%$ yield (scheme II, table I).

Table I: Characterization data of the compounds

\begin{tabular}{ccccc}
\hline Compounds & M.P. & Yield(\%) & $\mathrm{Rf}_{\mathrm{A}}$ & $\mathrm{Rf}_{\mathrm{B}}$ \\
\hline Aspirin & $135-137^{\circ} \mathrm{C}$ & 92 & ---- & ---- \\
1 & $175-178^{\circ} \mathrm{C}$ & 73 & 0.56 & 0.51 \\
2 & $116-118^{\circ} \mathrm{C}$ & 75 & 0.45 & 0.59 \\
3 & $165-168^{\circ} \mathrm{C}$ & 76 & 0.45 & 0.52 \\
4 & $137-140^{\circ} \mathrm{C}$ & 75 & 0.45 & 0.68 \\
\hline
\end{tabular}




\section{Scheme 1}

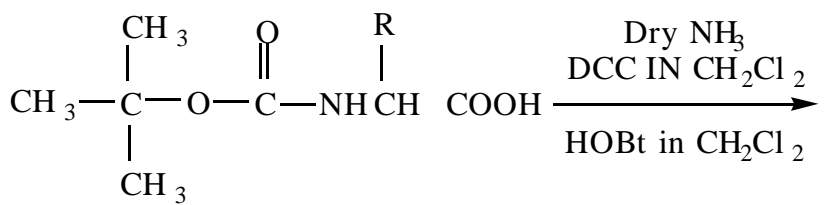

Boc - amino acid $1(a-b)$<smiles>[R]C(N)NC(=O)OC(C)(C)C</smiles>

TFA / $\mathrm{CH}_{2} \mathrm{Cl}_{2}$ $\mathrm{HCl} / \mathrm{THF}$ / E⿱ $\mathrm{N}$ Boc- Phe

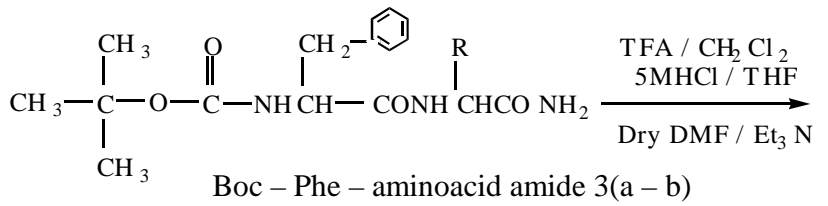
DCC in $\mathrm{CH}_{2} \mathrm{Cl}_{2}$<smiles>[R]C(NC(N)=O)C(=O)C(Cc1ccccc1)NC(=O)NCC(=O)OC(C)(C)C</smiles>
Boc - Gly - Phe - amino acid amide $4(a-b)$
TFA / $\mathrm{CH}_{2} \mathrm{Cl}_{2}$

$5 \mathrm{MHCl}$

Dry DMF / Et ${ }_{3} \mathrm{~N}$

Boc - Gly / $\mathrm{HOBt}$ in $\mathrm{CH}_{2} \mathrm{Cl}_{2}$<smiles>[R]C(NC(=O)CNC(=O)CNC(=O)OC(C)(C)C)C(=O)OC(C)(C)C</smiles>

Boc - Gly - Gly - Phe - aminoacid amide $5(a-b)$

62

M.Sekar et al, Hygeia.J.D.Med. Vol 3 (2), 2011, 48-56.

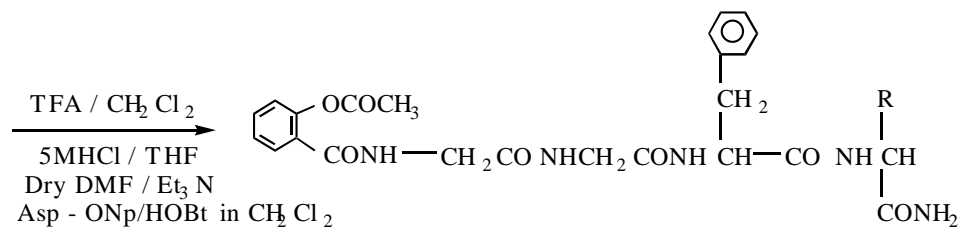

Asp - Gly - Gly - Phe - amino acid - $\mathrm{NH}_{2} \quad 1$ and 3

1a, 2a, 3a, 4a, 5a \& 1, $\mathrm{R}=-\mathrm{CH}_{2}-\mathrm{CH}_{2}-\mathrm{SCH}_{3}$

$1 \mathrm{~b}, 2 \mathrm{~b}, 3 \mathrm{~b}, 4 \mathrm{~b}, 5 \mathrm{~b} \& 3, \quad \mathrm{R}=-\mathrm{CH}_{2} \mathrm{CH}^{\mathrm{CH}_{\mathrm{CH}_{3}}} / \mathrm{CH}_{3}$ 
Scheme 2

$$
\begin{aligned}
& \mathrm{R}+\text { Super dry } \mathrm{CH}_{3} \mathrm{OH} / \mathrm{SOCl}_{2} \\
& \text { I Stirred for } 2 \mathrm{~h} \text { below } 0^{\circ} \mathrm{C}
\end{aligned}
$$

\section{$\mathrm{H}_{2} \mathrm{~N} \mathrm{CH} \mathrm{COOH}$}

Amino acid 6(a-b)
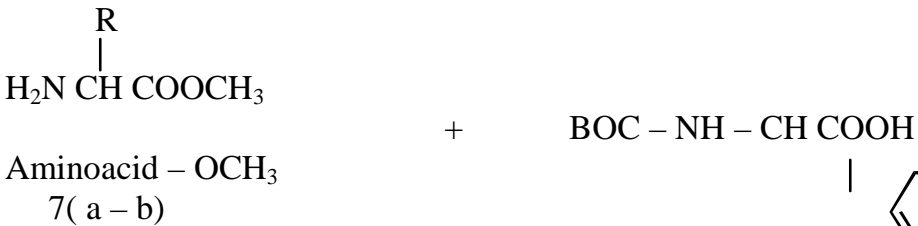

$7(\mathrm{a}-\mathrm{b})$

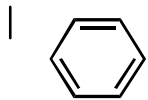

$$
\text { Boc - Phe }
$$

$\mathrm{DMF} / \mathrm{Et}_{3} \mathrm{~N}$ $\mathrm{HOBt} / \mathrm{CH}_{2} \mathrm{Cl}_{2}$

Boc-Phe $\mathrm{DCC} / \mathrm{CH}_{2} \mathrm{Cl}_{2}$

Stirred for $1 \mathrm{~h}$ at $0^{\circ} \mathrm{C}$,

$24 \mathrm{~h}$ at room temp<smiles>[R]C(NC(=O)C(Cc1ccccc1)NC(=O)OCc1ccccc1)C(=O)OC</smiles>

Boc $-\mathrm{Phe}-$ aminoacid $-\mathrm{OCH}_{3}$ $8(a-b)$

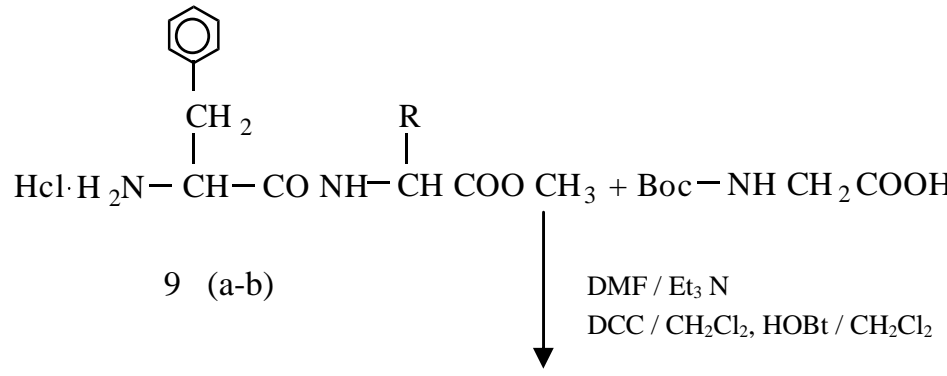<smiles>[R]C(NC(=O)C(Cc1ccccc1)NC(=O)CNC(=O)OCc1ccccc1)C(=O)OC</smiles>
$10(a-b)$ 


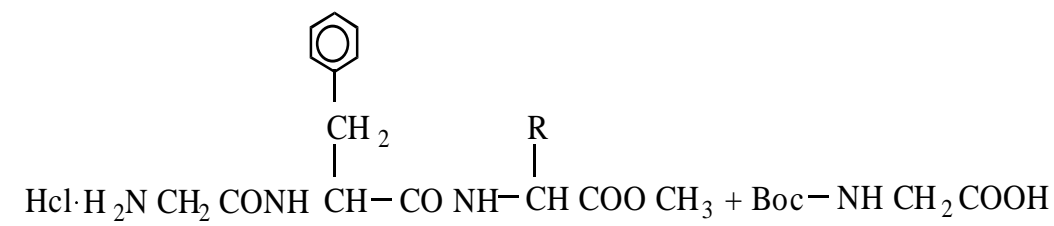

$11(a-b)$

$\mathrm{MF} / \mathrm{Et}_{3} \mathrm{~N}$

$\mathrm{HOBt} / \mathrm{CH}_{2} \mathrm{Cl}_{2}$

$\mathrm{DCC} / \mathrm{CH}_{2} \mathrm{Cl}_{2}$ at $0^{\circ} \mathrm{C}$

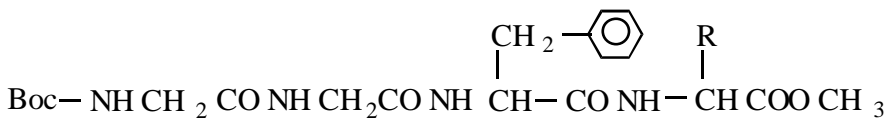

$12(a-b)$

TFA / $\mathrm{CH}_{2} \mathrm{Cl}_{2}$

$5 \mathrm{MHCl} / \mathrm{THF}$

$\mathrm{Hcl} \cdot \mathrm{H}_{2} \mathrm{~N} \mathrm{CH}_{2} \mathrm{CONH} \mathrm{CH}_{2} \mathrm{CONH} \mathrm{CH}-\mathrm{CO} \mathrm{NH}-\stackrel{\mathrm{CH} \mathrm{COO} \mathrm{CH}}{\mathrm{CH}_{2}-\mathrm{O}}$

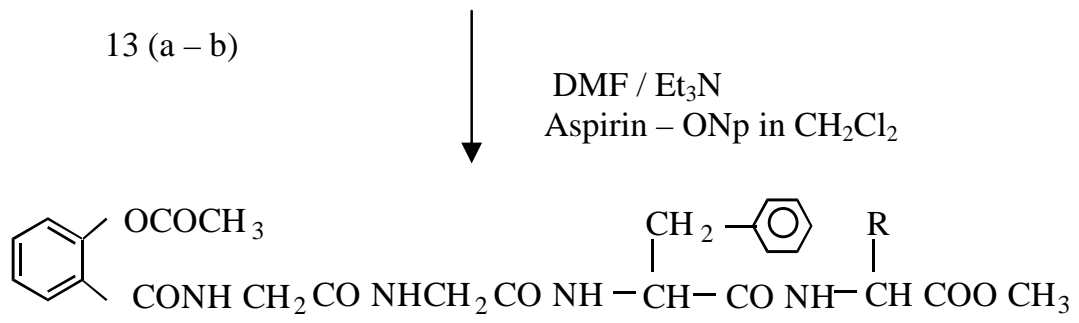

$14(a-b)$

6a, 7a, 8a, 9a, 10a, 11a, 12a, 13a, \&2 $\mathrm{R}=-\mathrm{CH}_{2}-\mathrm{CH}_{2} \mathrm{SCH}_{3}$

$6 \mathrm{~b}, 7 \mathrm{~b}, 8 \mathrm{~b}, 9 \mathrm{~b}, 10 \mathrm{~b}, 11 \mathrm{~b}, 12 \mathrm{~b}, 13 \mathrm{~b}, \& 4 \mathrm{R}=$

Data pertaining to a few selected compounds are as follows:

1.Asp-Gly-Gly-Phe-Met-NH 2 ;- M.Pt.(175-178 ${ }^{\circ}$ C); $\mathrm{IR}(\mathrm{KBr}) 3390 \mathrm{~cm}^{-1}$ (Asymm.NH),3188 $\mathrm{cm}^{-1}$ (symm NH), $3342 \mathrm{~cm}^{-1}(\mathrm{GONH}), 1678 \mathrm{~cm}^{-1}(>\mathrm{c}=\mathrm{O})$,

${ }^{1} \mathrm{HNMR} ;(400 \mathrm{MHZ})\left(\mathrm{DMSO}_{-} \mathrm{d}_{6}\right) \delta 2.27\left(-\mathrm{COCH}_{3}\right), \delta 7.8(-\mathrm{NH}-)$ and $\delta 8.4\left(-\mathrm{NH}_{2}\right)$;

Elemental analysis: Glycyl - Glycyl - phenylalanyl - Methionine amide of Aspirin. $\mathrm{C}_{27} \mathrm{H}_{33} \mathrm{O}_{7} \mathrm{~N}_{5} \mathrm{~S}$ (571) is found to have $\mathrm{C} 56.74 \%, \mathrm{H}=5.78 \%$ and $\mathrm{N} 12.26 \%$; calculated C $56.71 \% \mathrm{H} 5.32 \%$ and $\mathrm{N} 11.75 \%$.

3.Asp-Gly-Gly-Phe-Leu-NH ${ }_{2}$ :- $\operatorname{M.Pt}\left(165\right.$ to $\left.168^{\circ} \mathrm{C}\right)$; IR(KBr);3394cm $\left.{ }^{-1}{ }_{(\mathrm{A}} \mathrm{Symm} . \mathrm{NH}\right), 3207 \mathrm{~cm}^{-1}$ (symm.NH), $3351 \mathrm{~cm}^{-1}(\mathrm{GONH}), 1717 \mathrm{~cm}^{-1}(>\mathrm{c}=\mathrm{O})$,

${ }^{1} \mathrm{HNMR} ;(400 \mathrm{MHZ})\left(\mathrm{DMSO}-\mathrm{d}_{6}\right) \delta 2.5\left(-\mathrm{COCH}_{3}\right), \delta 8(-\mathrm{NH}-)$ and $\delta 7.95\left(-\mathrm{NH}_{2}\right)$;

Elemental analysis: Glycyl - Glycyl - phenylalanyl - Leucine amide of Aspirin. 
$\mathrm{C}_{28} \mathrm{H}_{35} \mathrm{O}_{7} \mathrm{~N}_{5}$ (553) is found to have $\mathrm{C} 60.76 \%, \mathrm{H}=6.33 \%$ and $\mathrm{N} 12.66 \%$.;

calculated $\mathrm{C} 60.2 \% \mathrm{H} 5.98 \%$ and $\mathrm{N} 12.32 \%$.

1a. Boc-Aminoacid (Boc-Met) M.Pt. $109-111^{\circ} \mathrm{C}$; IR (KBr); $3394 \mathrm{~cm}^{-1}$ (asymmetric NH), $3207 \mathrm{~cm}^{-1}$ (sym. NH), $3351 \mathrm{~cm}^{-1}$ (-CONH)., $1717 \mathrm{~cm}^{-1},(>\mathrm{C}=\mathrm{O})$,

${ }^{1} \mathrm{HNMR}$; $(400 \mathrm{MHz})\left(\mathrm{DMSO}-\mathrm{d}_{6}\right) ; \delta 2.5\left(-\mathrm{COCH}_{3}\right), \delta 8(\mathrm{~N}-\mathrm{H})$ and $\delta 7.95\left(-\mathrm{NH}_{2}\right)$.

Elemental analysis: $\mathrm{C}_{10} \mathrm{H}_{19} \mathrm{O}_{4} \mathrm{~S}(235)$ is found to have $\mathrm{C} 51.06 \%, \mathrm{H}=8.09 \%$ and $\mathrm{S} 13.62 \%$.; calculated $\mathrm{C} 50.9 \%$ $\mathrm{H} 9.12 \%$ and $\mathrm{S} 12.9 \%$.

1b. Boc-Aminoacid (Boc-Leu)

M.P. $85-88^{\circ} \mathrm{C}$; IR (KBr); 3390 $\mathrm{cm}^{-1}$ (Asymm.NH); $3188 \mathrm{~cm}^{-1}$ (symm.NH)., $3342 \mathrm{~cm}^{-1}(\mathrm{CONH}), 1678 \mathrm{~cm}^{-1}$ $(>\mathrm{C}=\mathrm{O})$,

${ }^{1} \mathrm{H}$ NMR: $\delta 2.27 \quad\left(-\mathrm{COCH}_{3}\right), \delta 8.2(-\mathrm{NH}-) \delta 8.4\left(-\mathrm{NH}_{2}\right)$.

Elemental analysis: $\mathrm{C}_{11} \mathrm{H}_{21} \mathrm{O}_{4}(195)$ is found to have $\mathrm{C} 67.69 \%, \mathrm{H}=10.77 \%$ and $\mathrm{O} 32.82 \%$.; calculated $\mathrm{C} 66.9 \%$ $\mathrm{H} 10.12 \%$ and $\mathrm{O} 31.93 \%$.

${ }^{1} \mathrm{H}$ NMR parameters of the aminoacid residues (1) and (3) are Asp - Gly (1) - Gly (2) - Phe (3) - X (4) - $\mathrm{NH}_{2}$

\begin{tabular}{clcc}
\hline Aminoacid residue & Parameters & X(4)Leu & X(4) Met \\
\hline Gly (1) & $\delta$ NH & 8.21 & 8.2 \\
& $\delta \mathrm{CH}_{2}$ & 3.2 & 3.4 \\
\hline Gly (2) & $\delta \mathrm{NH}$ & 8 & 3.8 \\
& $\delta \mathrm{CH}_{2}$ & 3.06 & 8 \\
\hline Phe (3) & $\delta \mathrm{NH}$ & 8 & 5.3 \\
& $\delta \mathrm{C}^{\alpha} \mathrm{H}$ & 4.5 & 3.4 \\
& $\delta \mathrm{CH}_{2}$ & 3.6 & 7.25 \\
\hline$-\mathrm{NH}_{2}$ & $\delta \mathrm{C}_{6} \mathrm{H}_{5}$ & 7.3 & 8.4 \\
$-\mathrm{COCH}_{3}$ & $\delta$ & 7.95 & 2.27 \\
\hline
\end{tabular}

The methyl resonance of methionine at $2.04 \mathrm{ppm}$, the isopropyl resonance of leucine at $4.5 \mathrm{ppm}^{14}$.

\section{Gastric - ulcer reducing property}

Male adult Wistar Albino rats were purchased from small animal department, Trichur, Agricultural College, Kerala. The animals were adapted to the laboratory condition for a week. Water and feed was provided ad libitum. The animals were divided into 3 groups and treated with four peptide derivatives and it is taken for histopathological studies. In histopathological studies, an incident of gastric ulcer formation was not observed in all the four compounds. This shows that they are free from gastric ulcer inducing property.

\section{Results and discussion:}

\section{Ulcer induction evaluation:}

Histopathological study was carried out to identify gastric ulcer inducing property. In histopathological studies, an incident of gastric ulcer formation was not observed in all the four compounds. This shows that they are free from gastric ulcer inducing property. The results of histopathological studies are given below: 


\section{Group I: Control rat}

The mucosa composed of mucosal glands, laminapropria and muscularis propria appears normal. The submucosa, muscularis propria and serosa appear normal - Normal histology shown in photograph 1.

\section{Group II: Rat treated with aspirin}

There is evidence of mucosal congestion, increased numbers (proliferation) of parietal cells and focal areas of atrophy. A mucosal infiltration by easinophils is also noted. Acute non-erosive gastritis shown in photograph -2

Group III :(i) Rat treated with aspirin and Asp - Gly - Phe - Leu - $\mathrm{NH}_{2}$

The mucosa, submucosa, muscularis propria and serosa appear normal. No vascular congestion (or) easinophil infiltration is noted. Complete reversal of pathological changes shown in photograph 3 .

(ii) Rats treated with aspirin and Asp - Gly - Gly - Phe - Leu - $\mathrm{NH}_{2}$

An inflammation characterized by infiltration of easinophils into mucosa and submucosa is noted. However there is no parietal cell hyperplasia or atrophy - persistence of early acute non-erosive gastritis shown in photograph- 4.

(iii)Rats treated with the aspirin and Asp-Gly-Phe-Met- $\mathrm{NH}_{2}$

An infiltration by eosinophils is noted in lamina propria and muscularis mucosa. Vascular congestion is also noted the submucosa, muscularis propria and serosa appear normal- Persistence of most of the pathological changes of acute non-erosive-gastritis shown in photograph -5 .

(iv) Rats treated with the aspirin and Asp-Gly-Gly-Phe-Met-NH

The mucosa, sub mucosa, muscularis propria and serosa appear normal. No vascular congestion or easinophil infiltration is noted complete reversal of pathological changes shown in photograph- 6 .

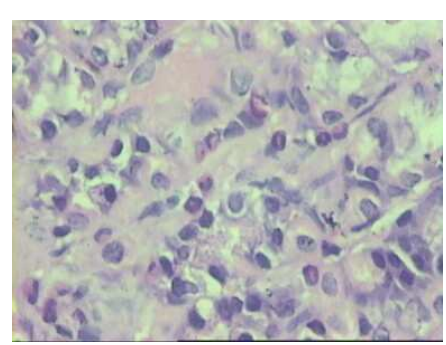

Photo-1

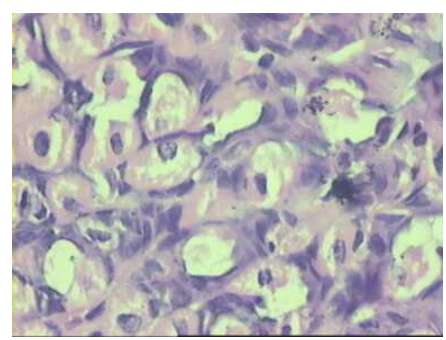

Photo-4

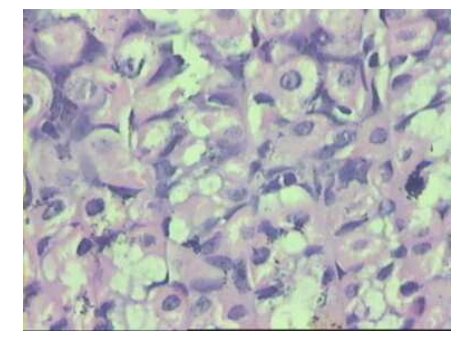

photo-2

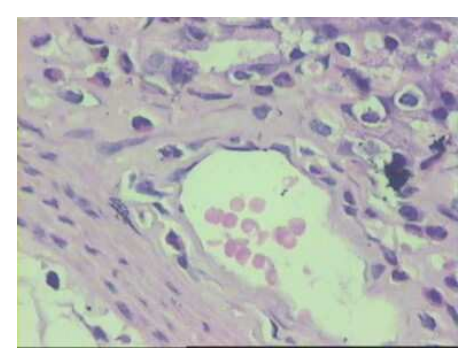

Photo-5

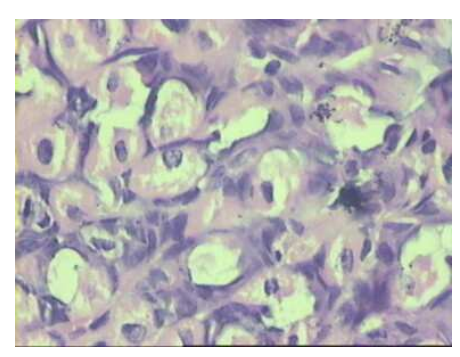

photo-3

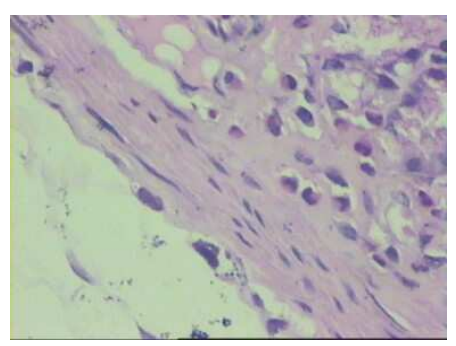

Photo-6 


\section{Acknowledgement:}

We thank the SIF, IISC, Bangalore for recording the NMR and IR Spectra. The author express thanks to the Secretary, the Principal and the management of Kongunadu Arts and Science College, Coimbatore, India for providing all the facilities to carry out this research work.

\section{References:}

1. Patrick G.L, Introduction to medicinal chemistry, Oxford. Univ, Press, 2000 pp.85-94.

2. David. A. Williams, William O. Foye, Principles of medicinal chemistry, 1981 pp. 91, Lea \& Febiger.

3. Andrew Wilson and Child, H.O, Applied pharmacology, The English Language Book Society and J \& A, Churchill Ltd., London 1968 pp. 359, 357.

4. Vogel's Text book of practical organic chemistry, $5^{\text {th }}$ edition ELBS

5. Yajima, H. \& Fuji, N, J. Chem, Soc, Chem. Comm, 1982 (115-116).

6. Kenner. G.W, Galpin I.J, and Ramage, R in "Peptides, structure and biological function", Gross, E. and Meienhofer, J. 2 Eds, pierce chemical Co., Rockford, Illinois, 1979, pp. 431-438.

7. Beluzzi, J.D. Grant. N., Garsky, V, Sarantakis, D, wise, C.D, and Stein, L, Nature, 260, 1976, 625.

8. Birscher, H.H, Hill, R.C, Romer, D, Cardinaux, F, Closse, A., Houser, D and Pless, J, Nature, 261, $1976,423$.

9. Snyder, S.H., Science, 209, 1980, 976

10. Bodanszky. M., and V.Du Vigneaud, J. Am. Chem. Soc., 81, 5689 (1959).

11. Khan S.A, and Sivanandaiah, K.M, Indian J. Chem. 15B, 1977; , 80 Schnabel, E, Justus gebigsAm, Chem, 702, (1967); 188 Grzonka, Z, and Lammek, B, Synthesis, 9, 1974, 661.

12. Kundu, B \& Mattur K.B., Indian J. Chem, 25B, 1986, 932.

13. Arno Bundi, Christoph Grathwohl, Journal of Magnetic resonance, 18, 1975, 191-198. 


\title{
Design, Synthesis and Biological evaluation of Pyrazole analogues of Natural Piperine
}

\author{
Anny Mathew ${ }^{1}$, Mary Sheeja T.L ${ }^{2}$, Arun Kumar.T ${ }^{3}$, K.Radha ${ }^{4}$ \\ 1, 2, 4. College of Pharmaceutical Sciences, Govt. Medical college, Thiruvananthapuram, Kerala, India,695011 \\ 3. Department of Molecular Biology, Rajiv Gandhi Centre for Biotechnology, Jagathy, Thiruvananthapuram, Kerala, India \\ Article history: Received: 2 August, 2011, revised: 25 August 2011, accepted: 27 August2011, Available online: 1 October 2011
}

\begin{abstract}
A series of pyrazole analogues of natural piperine were synthesized by removing the basic piperidine moiety from the piperine nucleus. Piperine upon hydrolysis and oxidation, converted to piperonal and allowed to condense with substituted acetophenone gave chalcone derivative and cyclized finally with thiosemicarbazide to form pyrazole derivatives of piperine. Docking studies were carried out against different targets like Cyclooxygenase, farnasyl transferase receptors. Majority of the synthesized chemical compounds showed good fit with the active site of all the docked targets.Compound 6a have shown significant anti inflammatory activity and $6 d$ and $6 c$ have shown significant anticancer activity when compared with standard drugs.
\end{abstract}

Key words: Piperine, piperonal, pyrazole, anti-inflammatory, anticancer, Cyclooxygenase, farnasyl transferase.

\section{Introduction}

Piperine has received enormous attention in the last two decades as a versatile bioactive molecule. The structure consists of three important components viz; methylene dioxy phenyl (MDP) ring, side chain with conjugated double bond and basic piperidine moiety attached through a carbonyl amide linkage. Piperine is also known to posses anti-inflammatory, analgesic, anti neoplastic, and anxiolytic activities. Pyrazole also posses anticancer and anti-inflammatory activities. Thus we become interested in the synthesis of piperine analogues that contains pyrazole moiety. Here we also take the advantage of microwave technique and evaluation of biological activities. Microwave assisted reaction have received great interest because of their simplicity in operation, enhanced reaction rates, product with high purity and better yield compared to those conducted by conventional method.

For correspondence.

kirjoanu@gmail.com,annaserahs@yahoo.com

Contact: +91 9446369945

Anny Mathew*, Mary Sheeja TL, Arun Kumar T, K Radha, H.J.D.Med., Vol. 3 (2), October 2011, pp.48-56. (C) 2011 Hygeia journal for drugs and medicines, all rights reserved. 22293590,09756221 


\section{Materials and methods}

\subsection{Anti inflammatory activity:}

The anti inflammatory activity of the synthesized compounds was determined by Human Red Blood Cell (HRBC) membrane stabilization method at doses of $100 \mu \mathrm{gm}, 500 \mu \mathrm{gm}$ and $1000 \mu \mathrm{gm}$. Diclofenac sodium was used as standard drug ${ }^{9,10,11,12}$. Control group was given Dimethyl sulphoxide (DMSO). The results obtained are reported in table no.8.

\subsection{Anticancer activity:}

The anticancer activity of the synthesized compounds were determined by MTT (3-(4,5Dimethylthiazol-2-yl)-2,5-di phenyl tetrazolium bromide, a yellow tetrazole) assay Method ${ }^{13}$. We have investigated the cytotoxic activity of the compounds in various cancer cell lines such as HeLa (Cervical cancer cell line), A375 (Skin cancer cell line), HCT116 (Colon cancer cell line), MCF7 (Breast cancer cell line). This study was carried out in the department of Molecular Biology, Rajiv Gandhi Centre for Biotechnology, Thiruvananthapuram, Kerala. The results are reported in table no.7.

\section{Experimental}

Melting points of the compounds were found out in an open capillary tube by electrically heated melting point apparatus were uncorrected. The synthesized compounds were purified by recrystallisation and Thin Layer Chromatography. IR spectra of the compounds were recorded using $\mathrm{KBr}$ pellets in the range of 4000- $500 \mathrm{~cm}^{-1}$ on a Jasco FTIR model 6200 in the College of Pharmaceutical Sciences, Medical College, Thiruvananthapuram. The ${ }^{1} \mathrm{H}$ NMR of the compounds were recorded in $\mathrm{CDCl}_{3}$. Chemical shifts were reported in parts per million downfield with reference to internal standard Tetra Methyl Silane (TMS)on Bruker Ultra Sheild DPX 400 in the Institute of Intensive Research in Basic Sciences, Mahatma Gandhi University, Kottayam. SMILES and C Log P values, Physico Chemical Properties, Analysis of Lipinski rule of five, Drug Likeness Analysis, prediction of activity spectra (PASS) of the Novel proposed analogues were carried out by using Chemsketch and molinspiration software.

Insilco ADME properties were screened by using the application Qikprop in maestro molecular modeling software. Docking studies were carried out against different targets like Cycloxygenase and farnasyl transferase receptors using Schrodinger software in College of Pharmaceutical sciences, Medical college, Thiruvananthapuram. The reactions were carried out in catalyst synthetic microwave oven and by conventional method. The physical and spectral data of the synthesized compounds were reported in the table No. 4,5and 6.

\subsection{Synthesis of piperic acid (2) from piperine (1):}

Piperine 1 (11.4 g, $0.04 \mathrm{~mol})$ was refluxed with methanolic $\mathrm{KOH}(20 \%, 500 \mathrm{ml})$ for $24 \mathrm{hrs}$. After completion of hydrolysis, methanol was distilled under reduced pressure. The resulting reaction mixture was suspended in hot water and acidified with $\mathrm{HCl}$ to $\mathrm{pH}$ less than 1. 
Yellow precipitate obtained was collected by filtration, washed with cold water and recrystallized from methanol to yield crystals of piperic acid. ${ }^{1,2,3 .}$ Yield: $59 \%, \mathrm{mp} 215-217^{\circ} \mathrm{c}$.

\subsection{Synthesis of piperonal (3) from piperic acid:}

Piperic Acid $2.18 \mathrm{~g}(0.01 \mathrm{~mol})$ was suspended in $150 \mathrm{ml}$ boiling $\mathrm{H}_{2} 0$, containing $4.2 \mathrm{~g}(0.05 \mathrm{~mol})$ sodium bicarbonate. To this hot solution, $3.16 \mathrm{~g}(0.02 \mathrm{~mol}) \mathrm{KMnO}_{4}$ in $75 \mathrm{ml}$ warm $\mathrm{H}_{2} 0$ added with a dropper over about $40 \mathrm{~min}$, with constant stirring. Added $25 \mathrm{ml}$ of Isopropyl alcohol. (To remove any remaining oxidizer) The warm brown solution was filtered to leave a slightly yellow solution. This was chilled overnight and recrystallized $\mathrm{d}^{4,5} .75 \%$ yield, $\mathrm{mp} 36-38^{\circ} \mathrm{C}$.

\subsection{Procedure for the Synthesis of 3-(1, 3-Benzodioxol-5-yl)-1-phenylprop-2-en-1-one (chalcone):}

Into a $10 \mathrm{ml}$ Erlenmeyer flask placed $0.24 \mathrm{~g}$ ( 2.0 mmoles $)$ of acetophenone, $0.30 \mathrm{~g}$ ( 2.0 mmoles $)$ of piperonal, $1 \mathrm{ml}$ of $95 \%$ ethanol, and $1 \mathrm{ml}$ of $10 \%$ sodium hydroxide solution. The mixture was stirred for 30 minutes during which time a solid forms. The reaction mixture was cooled and suction filtered using a Hirsch funnel, and recrystallized from a small amount $(<1 \mathrm{~mL})$ of $95 \%$ boiling hot ethanol and then allowed to cool slowly to room temperature ${ }^{6}$.

\subsection{Synthesis of 5-(1, 3-Benzodioxol-5-yl)-3-(substituted) phenyl-4, 5-dihydro-1H-pyrazol-1- carbothioamide (6a-h): \\ Conventional methods:}

To a solution of $\mathrm{NaOH}(1 \mathrm{~g}, 0.025 \mathrm{~mol})$ and chalcone derivatives $(5 \mathrm{a}-\mathrm{h})(0.01 \mathrm{~mol})$ in ethanol $(25 \mathrm{ml})$, thiosemicarbazide $(0.92 \mathrm{~g}, 0.01 \mathrm{~mol})$ was added slowly under stirring. After addition was completed, the reaction mixture was refluxed for $1 \mathrm{~h}$ and the solution was added to crush ice. The resulting solid was washed with ether and water, then filtered ${ }^{7}$. The crystals were washed thoroughly with ice-cold water, dried and recrystallized from appropriate solvent to give $6 \mathrm{a}-\mathrm{h}$ in $70 \%$ yield.

\subsubsection{Microwave method:}

A mixture of the chalcone $5 \mathrm{a}-\mathrm{h}(2.2 \mathrm{mmol})$ and thiosemicarbazide $(2 \mathrm{mmol})$ was dissolved in acetone (5 $\mathrm{ml}$ ) and ethanol $(5 \mathrm{ml})$, then $\mathrm{K}_{2} \mathrm{CO}_{3}(4.0 \mathrm{~g})$ was added and stirred vigorously. After $5 \mathrm{~min}$, the solvent was removed under vacuum and the dry powder was irradiated in a microwave oven for $3 \mathrm{~min}$ at $650 \mathrm{~W}$. After completion of reaction as followed by T.L.C. examination, chilled water was added to the reaction mixture. The solid product (6a-h) was obtained, which was filtered, dried and crystallized from hot ethanol ${ }^{8}$. 


\section{Result and discussion}

Insilico molecular analysis of different pyrazole analogues of piperine were done, all these compounds obeyed "Lipinski rule of five". These analogues were taken for computing molecular descriptors and then for synthesis. The designed analogues were synthesized by conventional and microwave procedures. Microwave procedure was simple efficient and showed better yield. The purity of the synthesized molecules was ascertained routinely by TLC, and melting point determinations were noted with an open capillary tube method and are uncorrected.

Docking studies were carried out against different targets like Cycloxygenase, farnasyl transferase receptors. Majority of the synthesized chemical compounds showed good fit with the active site of all the docked targets. Compounds $6 \mathrm{e}, 6 \mathrm{~h}$, which showed a maximum G-score were taken out for wet laboratory validations for their anti-inflammatory activities. Compound $6 \mathrm{~d}$ and $6 \mathrm{c}$ showed highest Glide score with anticancer drug target, Farnasyl Transferase.

Purity of the compound was done routinely by TLC and melting points. Acetone: Chloroform (3: 1) system was found to be ideal system for the development of compounds in TLC. The characterizations of the derivatives were carried out by various spectroscopic methods such as FTIR and NMR spectroscopy.

\subsection{Cytotoxicity Study:}

MTT assay was validated best method for screening cytotoxicity. The synthesized compound which shows good G-score was evaluated for the activity at different concentration 10-100 $\mu \mathrm{M}$. The drugs are administered as solution in DMSO and a DMSO control was also used. The drugs showed good cytotoxic behaviour and can be considered being potent cytotoxic agents.

\subsection{Anticancer activity of the compounds against various cancer cell lines:}

We have investigated the cytotoxic activity of the compounds in various cancer cell lines such as HeLa (Cervical cancer cell line), A375 (Skin cancer cell line), HCT116 (Colon cancer cell line), MCF7 (Breast cancer cell line). Compound 6d, 6c, 6b, 6f and 6a Sensitive to HCT116 (Colon cancer cell line), and compound 6g Sensitive to MCF7 (Breast cancer cell line).

\subsection{HRBC Membrane Stabilization Method:}

Anti inflammatory activities of the proposed analogue was carried out by using HRBC membrane stabilization method at doses of $100 \mu \mathrm{gm}, 500 \mu \mathrm{gm}$ and $1000 \mu \mathrm{gm}$. Diclofenac was used as the standard drug. Control group was given Dimethyl sulphoxide (DMSO). The analysis of the result shows that the compound 5-(1,3-benzodioxol-5-yl)-3-phenyl-1H-pyrazole-1-carbothioamide (6a) at doses of $100 \mu \mathrm{gm}$, $500 \mu \mathrm{gm}, 1000 \mu \mathrm{gm}$ shows significant activity. Study of the biological activity showed that the title compound is having significant anti inflammatory effect similar to that of Standard drug Diclofenac. 


\section{Summary and conclusion}

This research work was focused on design and development of pyrazole analogues of piperine as novel anticancer and anti inflammatory drugs. The present research work involved the preliminary insilico screening of various synthesized analogues for quantifying their drug likeness using molinspiration software. Eight analogues were synthesized in the wet lab by conventional and microwave procedures and comparative study for yield and reaction time was also carried out. Purity of the compounds were ascertained by consistency in melting point and $R f$ value and characterized by IR and ${ }^{1} \mathrm{HNMR}$ spectral studies.

The analogue also showed good binding affinity with Cycloxygenase and farnasyl transferase receptors, which was proved from the docking studies. The present study also highlights the importance of the structural features and $\mathrm{C} \log \mathrm{P}$ responsible for the activities.

Among the newly synthesized analogues 5-(1,3-benzodioxol-5-yl)-3-phenyl-1H-pyrazole-1carbothioamide (6a) was screened for anti inflammatory and showed good activity when compared with standard diclofenac.

The compound having best Glide score -8.16 , indicating good binding affinity with anticancer target, showed good activity in colon cancer cell lines (HCT116) which was proved from cytotoxic MTT assay.

\section{Scheme 1}
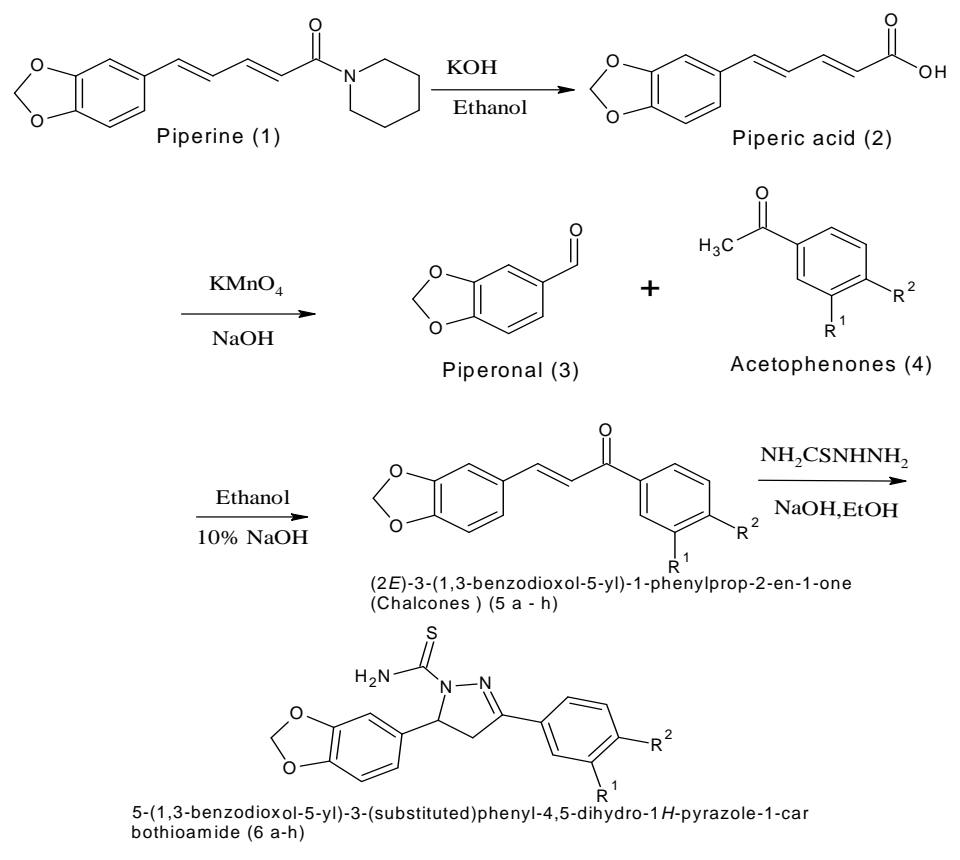

\begin{tabular}{ccc}
\hline comp & $\mathrm{R}^{1}$ & $\mathrm{R}^{2}$ \\
\hline $\mathrm{a}$ & $\mathrm{H}$ & $\mathrm{H}$ \\
$\mathrm{b}$ & $\mathrm{H}$ & $\mathrm{O}-\mathrm{CH}_{3}$ \\
$\mathrm{c}$ & $\mathrm{H}$ & $\mathrm{NH}_{2}$ \\
$\mathrm{~d}$ & $\mathrm{NH}_{2}$ & $\mathrm{H}$ \\
$\mathrm{e}$ & $\mathrm{OCH}_{3}$ & $\mathrm{H}$ \\
$\mathrm{f}$ & $\mathrm{OCH}_{3}$ & $\mathrm{OCH}_{3}$ \\
$\mathrm{~g}$ & $\mathrm{NO}_{2}$ & $\mathrm{H}$ \\
$\mathrm{h}$ & $\mathrm{H}$ & $\mathrm{NO}_{2}$ \\
\hline
\end{tabular}


Anny Mathew et al., H.J.D.Med. Vol. 3 (2), October 2011, 48-56.

Table 1: Characterization data of synthesized derivatives

\begin{tabular}{ccccc}
\hline Compound Code & Molecular formula & Molecular Weight & $\mathrm{mp}\left({ }^{0} \mathrm{C}\right)$ & $\mathrm{R}_{\mathrm{f}}$ value \\
\hline $6 \mathrm{a}$ & $\mathrm{C}_{17} \mathrm{H}_{15} \mathrm{~N}_{3} \mathrm{O}_{2} \mathrm{~S}$ & 323.377 & $226-229$ & 0.56 \\
$6 \mathrm{~b}$ & $\mathrm{C}_{18} \mathrm{H}_{17} \mathrm{~N}_{3} \mathrm{O}_{3} \mathrm{~S}$ & 355.410 & $222-225$ & 0.72 \\
$6 \mathrm{c}$ & $\mathrm{C}_{17} \mathrm{H}_{15} \mathrm{~N}_{3} \mathrm{O}_{2} \mathrm{~S}$ & 338.392 & $227-230$ & 0.41 \\
$6 \mathrm{~d}$ & $\mathrm{C}_{17} \mathrm{H}_{15} \mathrm{~N}_{3} \mathrm{O}_{2} \mathrm{~S}$ & 338.392 & $219-222$ & 0.61 \\
$6 \mathrm{C}$ & $\mathrm{C}_{18} \mathrm{H}_{17} \mathrm{~N}_{3} \mathrm{O}_{3} \mathrm{~S}$ & 355.410 & $223-226$ & 0.73 \\
$6 \mathrm{C}$ & $\mathrm{C}_{19} \mathrm{H}_{19} \mathrm{~N}_{3} \mathrm{O}_{4} \mathrm{~S}$ & 385.436 & $220-223$ & 0.63 \\
$6 \mathrm{~g}$ & $\mathrm{C}_{17} \mathrm{H}_{14} \mathrm{~N}_{4} \mathrm{O}_{4} \mathrm{~S}$ & 370.382 & $225-228$ & 0.77 \\
$6 \mathrm{~h}$ & $\mathrm{C}_{17} \mathrm{H}_{14} \mathrm{~N}_{4} \mathrm{O}_{4} \mathrm{~S}$ & 370.382 & $241-243$ & 0.75 \\
\hline
\end{tabular}

Table 2: Comparison of Different Synthetic Methods.

\begin{tabular}{ccccc}
\hline Compound Code & \multicolumn{2}{c}{ Conventional } & \multicolumn{2}{c}{ Microwave } \\
\cline { 2 - 5 } & Time(hr) & Yield \% & Time(min) & Yield \% \\
\hline 6a & 6 & 70 & 3 & 86 \\
6b & 6 & 73 & 3 & 89 \\
6c & 6 & 76 & 3 & 90 \\
6d & 6 & 75 & 3 & 92 \\
6e & 6 & 80 & 3 & 88 \\
6f & 6 & 77 & 3 & 87 \\
6g & 6 & 75 & 3 & 85 \\
6h & 6 & 78 & 3 & 9 \\
\hline
\end{tabular}

Table 3: Glide score of synthesized compounds based on G-score

\begin{tabular}{cccc}
\hline Targets & PDB ID & Compounds & G-Score \\
\hline Cycloxygenase & 3 KK6 & $6 \mathrm{a}$ & -12.41 \\
& & $6 \mathrm{~d}$ & -10.51 \\
Farnasyl Transferase & $3 \mathrm{E} 33$ & $6 \mathrm{~b}$ & -10.47 \\
& & $6 \mathrm{~d}$ & -8.16 \\
& & $6 \mathrm{c}$ & -7.68 \\
\hline
\end{tabular}


Fig. 1: Compounds Showing Stronger Binding with the Receptors

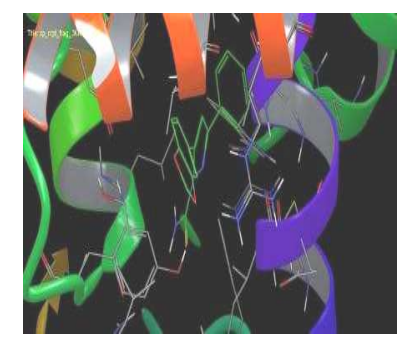

Compound (6a) with 3KK6

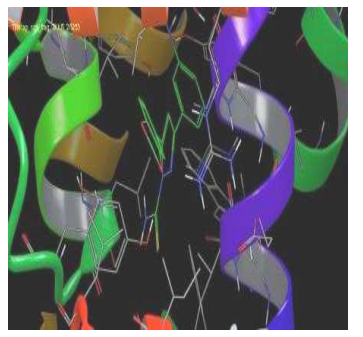

Compound (6d) with 3KK6

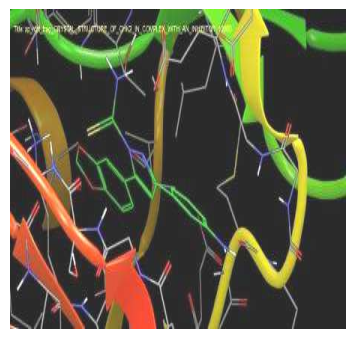

Compound (6d) with 3E33

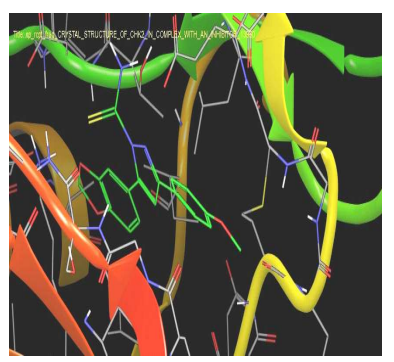

Compound (6c) with3E33

Table 4: Characteristic IR peaks of the Synthesized Compounds

\begin{tabular}{|c|c|}
\hline Compound & IR $\left(\mathrm{KBr} \mathrm{v} \mathrm{cm}^{-1}\right)$ \\
\hline Piperonal(3) & 2985(Ar-CH), 1601.59(Ar C=C), 1037.52(sym C-O-C), 1261.22(asym C-O-C), 1686.44(C=O), 2820,2720(CH) \\
\hline $5 \mathrm{a}$ & 2956(Ar-CH) 1659.45(C=O), 1590.32(Ar-C=C), 1018.23(Sym C-O-C Str), 1253.5, 1105.98(asym C-O-C). \\
\hline $5 b$ & 2956(Ar-CH) 1652.7(C=O),1583.27(Ar-C=C),1018.23(SymC-O-CStr), 1253.5, 1105.98(asym C-O-C), 1098.26(Ar-OCH) \\
\hline $5 \mathrm{c}$ & 1642(C=O), 1597.73(C=C), 3457.74, 3346.85(ArNH), 1034.02(sym C-O-C), 1243(asy m C-O-C). \\
\hline $5 \mathrm{~d}$ & 3424.96(Ar-CH),1655.59(C=O),1580.38(C=C),1036.55(sym C-O-C),1267.97(asym C-O-C) \\
\hline $5 \mathrm{f}$ & 2925.1(Ar-CH)1652.7(C=O),1583.27(Ar-C=C), 1018.23(Sym C-O-C Str), 1253.5,1105.98(asym C-O-C),1495.38(Ar-OCH) \\
\hline $5 \mathrm{~g}$ & 2956(Ar-CH) 1659.45(C=O),1590.32(Ar-C=C), 1018.23(Sym C-O-C Str), 1253.5,1105.98(asym C-O-C).1521.41(Ar- $\left.\mathrm{NO}_{2}\right)$ \\
\hline $6 a$ & 2925(CH Str)3343.96(NH),2360.44, 1100 (C=S)1468.53-1579.41 (C=N,N-N combined vib)1247.72( asym C-O-C),1040.41(symC-O-C), \\
\hline $6 \mathrm{~b}$ & $\begin{array}{l}\text { 3337.21(N-H), 1173.47,2361.41(C=S)1356.68(C-N),1579.41(C=N)1469.49,1579(C=N,N-N combined vib)1248.68(asymC-O-C), 1038.48(sym C-O-C),1000-1248.68(s, m Aryl O- } \\
\text { CH3) }\end{array}$ \\
\hline $6 \mathrm{c}$ & $2362.37,1050.11(\mathrm{C}=\mathrm{S}), 1483.96,1595.81(\mathrm{C}=\mathrm{N}, \mathrm{N}-\mathrm{N}$ combined vib)1234.22symC-O-C),1250.10(asymC-O-C) \\
\hline $6 \mathrm{~d}$ & 3330.46(NH), 2360.44(C=S)1484.92,1572.66(C=N,N-N combined vib) \\
\hline $6 \mathrm{f}$ & 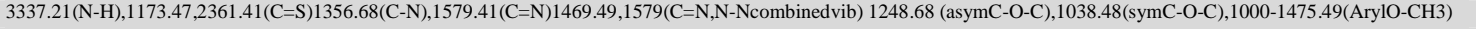 \\
\hline $6 \mathrm{~g}$ & 3237.14(CH Str)3343.96(NH),2360.44,1459.57(C=S)1468.53-1579.41(C=N,N-N combined vib)1247.72( asym C-O-C),1040.41(symC-O-C), \\
\hline
\end{tabular}

Table 5: Characteristic ${ }^{1} \mathrm{H}$ NMR peaks of the synthesized analogues

\begin{tabular}{|c|c|}
\hline compound & ${ }^{1} \mathrm{H} \mathrm{NMR}\left(\mathrm{CDCl}_{3}\right) \delta \mathrm{ppm}$ \\
\hline $6 a$ & $6.5-7(8 \mathrm{H}, \mathrm{Ar}-\mathrm{H}), 5.9\left(2 \mathrm{H}, \mathrm{CH}_{2}\right), 3.9(1 \mathrm{H}, \mathrm{CH}), 1.5-2.2\left(4 \mathrm{H}, \mathrm{CH}_{2}, \mathrm{NH}_{2}\right)$ \\
\hline $6 \mathrm{~b}$ & 6.5-7(7H, Ar- $\left.\mathrm{H}), 5.9) 2 \mathrm{H}, \mathrm{CH}_{2}\right) 3.9-4\left(4 \mathrm{H}, \mathrm{CH}, \mathrm{Ar}-\mathrm{OCH}_{3}\right), 1.8-2\left(4 \mathrm{H}\left(\mathrm{CH}_{2}, \mathrm{NH}_{2}\right)\right.$. \\
\hline $6 \mathrm{c}$ & 6.5-7(7H, Ar-H), 5.9(2H, CH $), 3.9-4.2\left(3 \mathrm{H}, \mathrm{CH}, \mathrm{Ar}-\mathrm{NH}_{2}\right), 1.8-2\left(4 \mathrm{H}, \mathrm{CH}_{2}, \mathrm{NH}_{2}\right)$. \\
\hline $6 \mathrm{~d}$ & 6.5-7(7H, Ar-H), 5.9(2H, CH2), 3.9-4(3H,CH,Ar- $\left.\mathrm{NH}_{2}\right), 1.8-2\left(4 \mathrm{H}, \mathrm{CH}_{2}, \mathrm{NH}_{2}\right)$. \\
\hline $6 f$ & 6.5-7(7H, Ar-H), 5.9)2H, $\left.\mathrm{CH}_{2}\right) 3.5-4.1\left(6 \mathrm{H}, \mathrm{CH}, \mathrm{Ar}-\mathrm{OCH}_{3}\right), 1.8-2\left(4 \mathrm{H}\left(\mathrm{CH}_{2}, \mathrm{NH}_{2}\right)\right.$. \\
\hline $6 \mathrm{~g}$ & $6.5-7(7 \mathrm{H}, \mathrm{Ar}-\mathrm{H}), 5.9\left(2 \mathrm{H}, \mathrm{CH}_{2}\right), 3.9(1 \mathrm{H}, \mathrm{CH}), 1.5-2.2\left(4 \mathrm{H}, \mathrm{CH}_{2}, \mathrm{NH}_{2}\right)$ \\
\hline
\end{tabular}



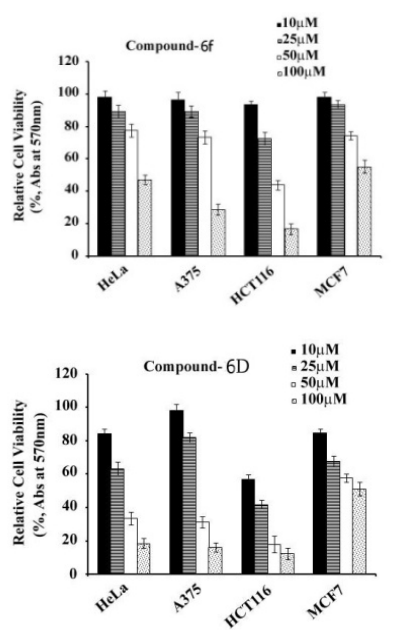
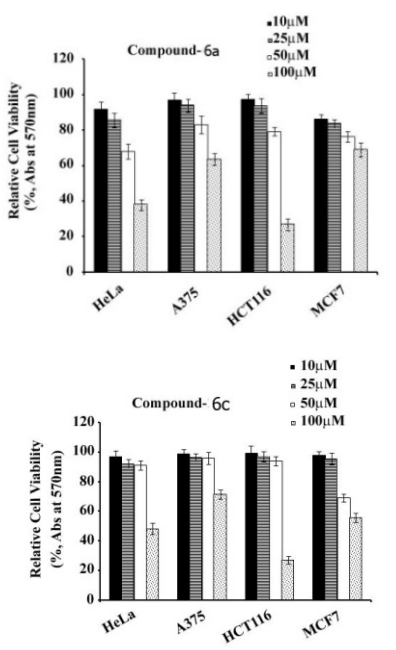
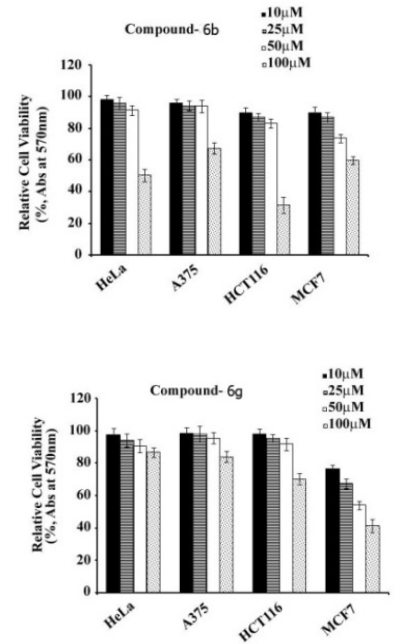

Fig: 2 .Relative cell viability in various cancer cell lines.

Table 7: Cells and their IC50 based on sensitivity.

\begin{tabular}{|c|c|c|c|c|}
\hline \multirow[t]{2}{*}{ Compound } & \multicolumn{4}{|c|}{ IC50 $(\mu \mathrm{M})$} \\
\hline & $\mathrm{HeLa}$ & A375 & HCT116* & MCF7* \\
\hline $6 \mathrm{~d}$ & 37.57 & 36.32 & $11.59^{* *}$ & 102.58 \\
\hline $6 c$ & 96.46 & 175.37 & $68.42^{*}$ & 112.94 \\
\hline $6 b$ & 100.76 & 154.08 & $73.20 *$ & 124.40 \\
\hline $6 \mathrm{~g}$ & 372.57 & 309.40 & 166.44 & $54.32 *$ \\
\hline $6 f$ & 94.80 & 70.10 & $44.42 *$ & 111.45 \\
\hline $6 a$ & 78.36 & 137.40 & $68.45^{*}$ & 161.29 \\
\hline
\end{tabular}

* Sensitive cells and their IC50.

Table 8: Anti-inflammatory study of 5-(1, 3-benzodioxol-5-yl)-3-phenyl-1H-pyrazole-1-carbothioamide (6a) compared with Diclofenac.

\begin{tabular}{|c|c|c|c|}
\hline Treatment & Concentration in $\mu \mathrm{g} / \mathrm{ml}$ & Absorbance & $\%$ inhibition of Membrane lysis \\
\hline \multirow{4}{*}{ Compound $6 \mathrm{a}$} & 100 & $0.888 \pm 0.012$ & $50 *$ \\
\hline & & & \\
\hline & 500 & $0.592 \pm 0.025$ & $66.66^{*}$ \\
\hline & 1000 & $0.273 \pm 0.017$ & $84.62 * *$ \\
\hline Diclofenac & 100 & $0.202 \pm 0.02$ & 88.62 \\
\hline
\end{tabular}




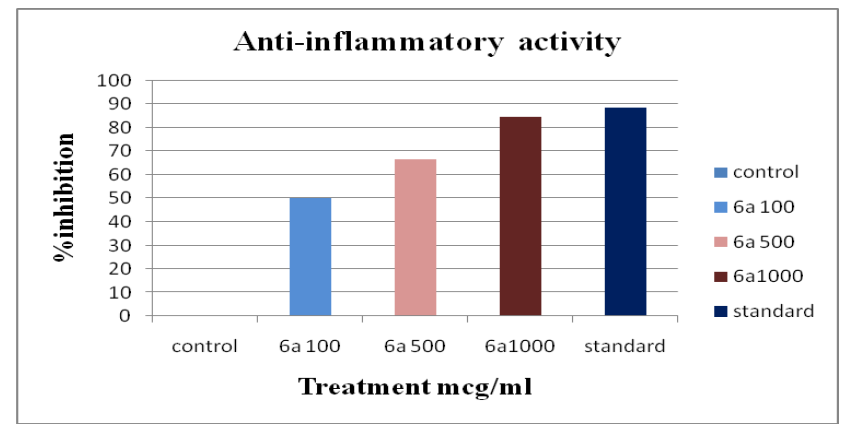

Fig: 3: Anti-inflammatory study of 5-(1, 3-benzodioxol-5-yl)-3-phenyl-1H-pyrazole-1-carbothioamide (6a) compared with Diclofenac.

\section{References}

1. Inder Pal Singh, Shreyans Kumar Jain, Amaneeep Kour. Synthesis and antileishmanial activity of Piperoyl- Amino acid conjugates.European Journal of Medicinal Chemistry 2010; 04:33.

2. Welisson da Silva Ferreira, Leonardo Freire-de-Lima, V1'ctor Barbosa Saraiva. Novel 1,3,4-thiadiazolium-2-phenylamine chlorides derived From natural piperine as trypanocidal agents, Chemical and biological studies. Bioorganic \& Medicinal Chemistry 2008; 16: $2984-2991$.

3. G:IthesisIpiperonal files\Piperic acid - Wikipedia, the free encyclopedia.mht.

Available from: URL: http://www.sciencemadness.org/talk/viewthread.php?tid=4465.

Availble G:Ithesis lpiperonal files Piperonal - LoveToKnow 1911.mht.

Available from: http://www.chem.wisc.edu/courses/342/Fall2006/Experiment_10.pdf

7. M. Shekarchia, M. Pirali-Hamedania,b, L. Navidpourb et al.Synthesis antibacterial andAntifungal Activities of 3-Aryl-5-(pyridine-3-yl)-4,5dihydropyrazole-1-carbothioamide Derivatives. Iran. Chem; 2008; 5:150-158.

8. Vimesh M. Patel and Kishor R. Desai. Eco-friendly synthesis of fluorine-containing pyrazoline derivatives over potassium carbonate. Arkivoc 2004;1: 123-129.

9. Mao J, Yuan H, Wang Y et al.Synthesis of 5-(2, 8-Bis (trifluoromethyl) quinolin-4-yloxymethyl) isoxazole-3-carboxylic acid ethyl ester,Bioorg Med Chem Lett 2010; 20(3):1263-8.

10. G. Q. Liu, S. Algeri, A. Ceci, S. Garattini et al. Stimulation Of Serotonin Synthesis In Rat Brain After Antiepilepsirine, An Antiepileptic Piperine Derivative. Biochemical Pharmocology 1984; 33:3883-3886.

11. E.S. Sunila, G. Kuttan. Immunomodulatory and antitumor activity of Piper longum Linn. and piperine. Journal of Ethnopharmacology, 2004; 90:339346.

12. Song Lia; Che Wangab, Wei Lic, Kazuo Koikec et al. Antidepressant-like effects of piperine and its derivative, antiepilepsirine. Journal of Asian Natural Products Research, 2009; 5: 421-430.

13. checkpoint lab/protocols/ MTT; T. Horton Checkpoint lab/protocols/MTT; 1994. 


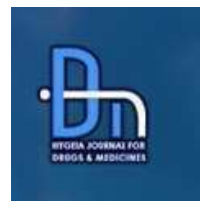

\title{
Simultaneous Multicomponent Spectrophotometric analysis of Ampicillin and Probenecid in Pharmaceutical formulation by Derivative spectroscopy
}

Thomas Kurian* and Jose Kurien

College of Pharmaceutical Sciences, Govt. Medical College, Kottayam, Kerala, India.686008.

Article history: Received: 2 August, 2011, revised: 27 August2011, 2011, accepted: 1 Sept.2011, Available online: 1 October 2011

\begin{abstract}
:
A simple, fast and precise simultaneous multicomponent derivative spectrophotometric method has been developed for simultaneous determination of Ampicillin and Probenecid in pharmaceutical formulation. The first derivative spectra has absorption maxima at 222.2nm for Ampicillin and $288 \mathrm{~nm}$ for Probenecid in $0.1 \mathrm{~N} \mathrm{NaOH}$ used as solvent. The peak with good absorption at different concentrations, obeyed Beer Lambert law only was chosen. Both Ampicillin and Probenecid showed linearity in the range of 10 to $50 \mu \mathrm{g} / \mathrm{ml}$ concentration.
\end{abstract}

Keywords: Ampicillin, Probenecid, simultaneous, multicomponent, derivative spectrophotometric method

\section{Introduction}

Ampicillin $^{2-4}$ is chemically 6-[(Amino phenyl acetyl) amino]-3, 3-dimethyl-7-oxo-4-thia-1-azabicyclo [3.2.0] heptane-2-carboxylic acid. It is sparingly soluble in cold water (1 in 50). It is insoluble in alcohol and acetone. It is soluble in dilute solutions of acids and alkali hydroxides. Ampicillin trihydrate is an antibiotic active against mainly gram positive bacteria and some gram negative bacteria. It is used for the treatment of infections due to streptococci and H.influenzae. It is used in urinary tract infections and respiratory tract infections. It is also used in meningitis, biliary tract infections etc.

Probenecid is a uricosoric agent used in gout therapy. When Ampicillin is co-administered with Probenecid, the renal excretion of Ampicillin is inhibited. The combination is used in gastrointestinal tract and respiratory tract infections.

*For correspondence.

thoku_ply@yahoo.com

Thomas Kurian and JoseKurien, H.J.D.Med. Vol. 3 (2), October 2011, pp57-61.

(C) 2011 Hygeia journal for drugs and medicines, all rights reserved. 2229 3590, 09756221 
Literature survey revealed that for Ampicillin and Probenecid combination, the extractive spectrophotometric method ${ }^{6,9,10}$ and estimation in biological fluids ${ }^{7,8}$ are available.<smiles>CC1(C)S[C@@]2(C)[C@H](NC(=O)[C@@H](N)c3ccccc3)C(=O)N2C1C(=O)O</smiles>

Ampicillin

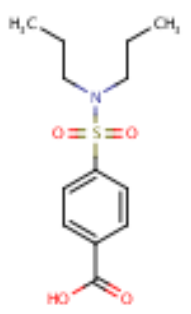

Probenecid

The United States Pharmacopoeial method ${ }^{11}$ involves iodometric method for Ampicillin and HPLC method for Probenecid. The present study aims in the development of simple, rapid, accurate and sensitive method for simultaneous estimation of Ampicillin and Probenecid in combined dosage forms using $0.1 \mathrm{~N}$ Sodium hydroxide as solvent using derivative spectroscopy.

\section{Experimental}

Pure samples of Ampicillin trihydrate $(99.54 \%$ w/w) was obtained as a gift sample Smith Kline Beecham Pharmaceuticals, Bangalore. Probenecid B.P. $(99.91 \%$ w/w) was obtained as a gift sample from American Remedies, Chennai. Marketed formulations were taken for study, which contained Ampicillin and Probenecid 250mg each. Shimadzu 160A UV-VISIBLE recording spectrophotometer was used for analysis.

\section{Method development}

Ampicillin $1 \mathrm{mg} / \mathrm{ml}$ and Probenecid $1 \mathrm{mg} / \mathrm{ml}$ stock solution in $0.1 \mathrm{~N}$ sodium hydroxide were prepared. Further dilutions were done to get a concentration of $10 \mu \mathrm{g} / \mathrm{ml}$ of Ampicillin and $10 \mu \mathrm{g} / \mathrm{ml}$ of Probenecid. The solutions were scanned and the first derative spectrum for Ampicillin was determined at $222.2 \mathrm{~nm}$ and that of Probenecid was determined at $288 \mathrm{~nm}$ against $0.1 \mathrm{~N}$ sodium hydroxide as blank. The absorbance values are recorded in table 1. Both Ampicillin and Probenecid showed linearity in the range of $10 \mu \mathrm{g} / \mathrm{ml}$ to $50 \mu \mathrm{g} / \mathrm{ml}$.The first derivative spectra of Ampicillin, Probenecid and the mixture of Ampicillin and Probenecid are shown in figure 1,2 and 3.

\section{Analysis of formulation}

Twenty tablets each containing 250mg of Ampicillin and Probenecid were weighed and the average weight was calculated. The tablets were crushed together to a fine powder and a quantity of powder equivalent to $50 \mathrm{mg}$ each of Ampicillin and Probenecid was dissolved in 0.1N Sodium hydroxide, filtered through Whatman filter paper. 


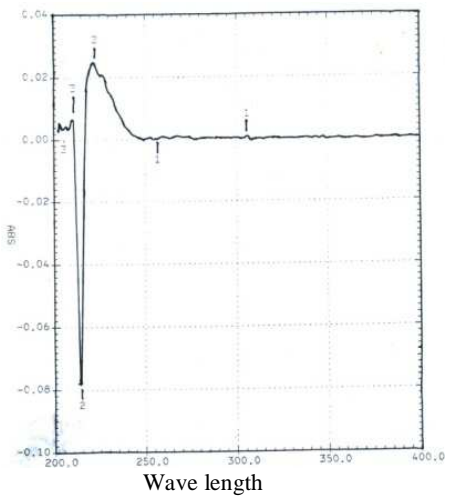

Fig. 1 First derivative spectra of Ampicillin

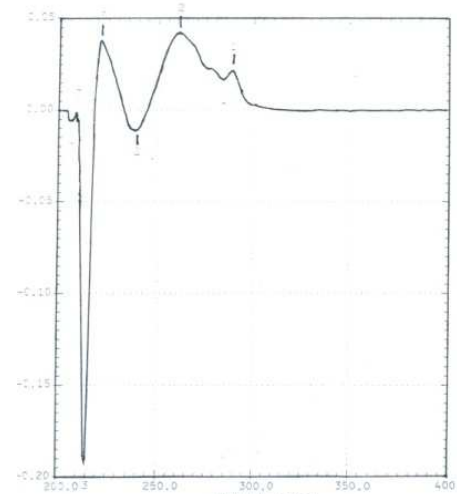

Fig.3 First derivative spectra of

Ampicillin Probenecid combination

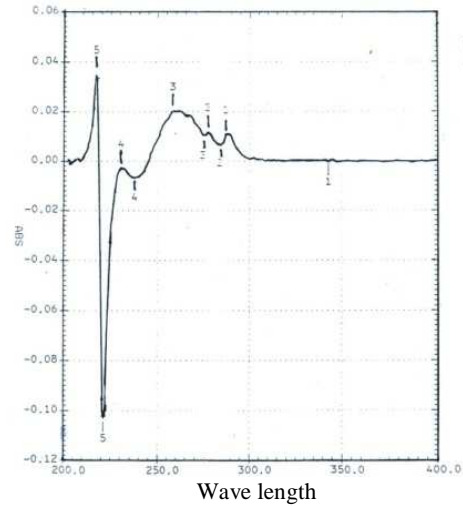

Fig. 2 First Derivative spectra of Probenecid

More amount of solvent was passed and the volume was finally made to $50 \mathrm{ml}$ with $0.1 \mathrm{~N}$ Sodium hydroxide. The solution was further diluted to get $20 \mu \mathrm{g} / \mathrm{ml}$ of Ampicillin and $20 \mu \mathrm{g} / \mathrm{ml}$ of Probenecid. The first derivative spectrum of the solution was obtained against 0.1 Normal sodium hydroxide as blank, figure 3. The absorbance of the solution was observed near 222.2nm for Ampicillin and at $288 \mathrm{~nm}$ for Probenecid. The amount of Ampicillin and Probenecid was then calculated by extrapolation using calibration curve of standard solutions.

\section{Recovery Experiments}

In order to confirm the suitability and reliability of the proposed method, a known quantity of Ampicillin and Probenecid were added to previously analysed samples and the mixtures were analysed by the proposed method. $5 \mathrm{ml}$ aliquot of the pre- analysed sample was transferred to a $10 \mathrm{ml}$ standard flask and $5 \mathrm{ml}$ of standard solution containing $10 \mu \mathrm{g} / \mathrm{ml}$ of Ampicillin and $10 \mu \mathrm{g} / \mathrm{ml}$ of Probenecid were added. 
Then the procedure described under preparation of standard curve was followed. The results of the recovery studies are shown in the table.2

Table 1. Data for Beer's law Plot for Ampicillin

\begin{tabular}{ccc}
\hline Concentration $(\mu \mathrm{g} / \mathrm{ml})$ & $\lambda \max (\mathrm{nm})$ & Absorbance* $^{*}$ \\
\hline 10 & 222.2 & 0.025 \\
20 & 222.2 & 0.039 \\
30 & 222.2 & 0.056 \\
40 & 222.2 & 0.070 \\
50 & 222.2 & 0.088 \\
\hline Conc. $=635.95 \times$ Absorbance -5.306 & $*$ Average of 3 determinations
\end{tabular}

Conc. $=635.95 \times$ Absorbance $-5.306 *$ Average of 3 determinations

Table 2. Data for Beer's law Plot for Probenecid

\begin{tabular}{ccc}
\hline Concentration $(\mu \mathrm{g} / \mathrm{ml})$ & $\lambda \max (\mathrm{nm})$ & Absorbance* \\
\hline 10 & 288.0 & 0.011 \\
20 & 288.0 & 0.021 \\
30 & 288.0 & 0.032 \\
40 & 288.0 & 0.042 \\
50 & 288.0 & 0.051 \\
\hline Conc. $=990.60 \times$ Absorbance $-1.0772 *$ Average of 3 determinations
\end{tabular}

Table 3. Data for analysis of formulations of Ampicillin and Probenecid

\begin{tabular}{|c|c|c|c|c|c|c|}
\hline \multirow[b]{2}{*}{ Drug } & & \multirow[b]{2}{*}{ Absorbance } & \multicolumn{2}{|c|}{ Amount (mg/tablet)* } & \multirow[b]{2}{*}{$\%$ label Claim } & \multirow[b]{2}{*}{$\begin{array}{l}\% \text { Recovery } \\
\text { Mean } \pm \text { SD* }\end{array}$} \\
\hline & & & Labelled & $\begin{array}{c}\text { Found } \\
\text { Mean } \pm \text { SD }\end{array}$ & & \\
\hline Ampicillin & 222.2 & 0.038 & 250 & $235.74 \pm 1.25$ & $94.2 \pm 0.356$ & $98.6 \pm 0.45$ \\
\hline Probenecid & 288 & 0.022 & 250 & $258.9+0.98$ & $103.5+0.364$ & $100.2+0.75$ \\
\hline
\end{tabular}

* Average of 5 determinations

\section{Results and Discussion}

The Ultraviolet first derivative spectra of Ampicillin and Probenecid in $0.1 \mathrm{~N}$ sodium hydroxide showed absorption maxima at $222.2 \mathrm{~nm}$ and $288 \mathrm{~nm}$. Both Ampicillin and Probenecid showed linearity at 10 to 50 $\mu \mathrm{g} / \mathrm{ml}$ concentration. The results of the method were is good agreement with the label claim of the Formulations. The recovery studies were done and it also showed good results.

\section{Conclusion}

The developed method can be used for the routine analysis of Ampicillin and Probenecid in combination. The method provided adequate accuracy and precision. 
Thomas Kurian et al., H.J.D.Med. Vol.3 (2), October 2011, pp.57-61.

\section{References}

1. Alfred Goodman and Gilman's The Pharmacological Basis of Therapeutics, $8^{\text {th }}$ edition, 1078

2. The Merck Index-11 ${ }^{\text {th }}$ edition, $622,1230$.

3. Martindale Extra Pharmacopoeia, $29^{\text {th }}$ edition. 116, 493

4. Clarke's Isolation and Identification of drugs, $2^{\text {nd }}$ edition, 351,923

5. G.H Jeffery, .J Basset, J Mendham, RC Denny, Vogel's text book of Quantitative Chemical Analysis- ${ }^{\text {th }}$ edition, 668-670.

6. Volmer P.J, Chastoney R, Haneke C. Journal of Association of Official Analytical Chemists, 1977, 1345-1349.

7. Campins Falco PHerraez R Sevillane Cabeza A. Chromatographia, 1993, 317-320.

8. Hansen Moller J Schmit U. Journal of Pharmaceutical and Biomedical analysis, 9(1) 1991, 65-73.

9. Munson J W Papadimatriou-D De Luca. Journal of Pharmaceutical sciences, 1979, 1333-1335.

10. Choudhury C. Indian Journal of Pharmaceutical Sciences, 1976, 124-126.

11. United States Pharmacopoeia, 1985, 62, 63,180,879. 